WIDER Working Paper 2017/85

Land and agronomic potential for biofuel production in Southern Africa

Graham von Maltitz and Marna van der Merwe*

April 2017

United Nations University World Institute for Development Economics Research 
Abstract: The Southern African region, from a purely biophysical perspective, has huge potential for biofuel production, especially in Mozambique and Zambia. Although many of the soils are sandy and acidic, with careful management and correct fertilization, they should be highly productive. We suggest that sugarcane is the crop most easily mobilized for biofuel. A number of other crops, such as sweet sorghum, cassava, and tropical sugar beet, have good potential but will need further agronomic and processing technology investigations.

Keywords: biofuel, Southern Africa, production potential, crop yields, sugarcane, cassava JEL classification: Q40, Q42, Q16

Acknowledgements: This research was supported by UNU-WIDER.

* CSIR Pretoria, South Africa, corresponding author: gvmalt@csir.co.za

This study has been prepared within the UNU-WIDER project on 'Regional growth and development in Southern Africa'.

Copyright (C) UNU-WIDER 2017

Information and requests: publications@wider.unu.edu

ISSN 1798-7237 ISBN 978-92-9256-309-7

Typescript prepared by Joseph Laredo.

The United Nations University World Institute for Development Economics Research provides economic analysis and policy advice with the aim of promoting sustainable and equitable development. The Institute began operations in 1985 in Helsinki, Finland, as the first research and training centre of the United Nations University. Today it is a unique blend of think tank, research institute, and UN agency_providing a range of services from policy advice to governments as well as freely available original research.

UNU-WIDER acknowledges specific programme contribution from the National Treasury of South Africa to its project 'Regional Growth and Development in Southern Africa' and core financial support to its work programme from the governments of Denmark, Finland, Sweden, and the United Kingdom.

Katajanokanlaituri 6 B, 00160 Helsinki, Finland

The views expressed in this paper are those of the author(s), and do not necessarily reflect the views of the Institute or the United Nations University, nor the programme/project donors. 
This report considers the potential availability of land and crops for biofuel expansion in Southern Africa. It is based on a regional-level review of data and is designed to highlight regional-level opportunities and constraints. It does not attempt to concentrate on specific national-level issues (which are covered in more detail in two case studies in this series, one for Mozambique and one for Zambia); nor does it consider the multitude of social factors that might provide either opportunities for or constraints to biofuel expansion. These social issues are considered in other working papers in this series.

Section 2 of the paper looks at land constraints. It uses an exclusionary approach, i.e. it identifies all the factors that might exclude land from biofuel expansion and develops a map of these exclusions. Land that is not excluded is therefore land where biofuel expansion might be possible. It is important to realize that the areas identified as having potential would still need local-level verification before any project could be considered. The mapping does, however, give a good regional overview of where good production areas (from a biophysical perspective) are likely to be located.

Biofuel can, in theory, be made from almost any crop. However, the current (first-generation) technologies are based on either oils (for biodiesel) or simple fermentation processes of sugars or starches (for ethanol). A separate report in this series considers the potential of second-generation technologies, but in the short term any industry in the sub-region is likely to be based on firstgeneration technologies. For these technologies it is crops that produce high yields of oils or sugars and starches that offer the most potential. For second-generation biofuels, any crop that can produce high biomass has potential. Section 3 of the report comprises a screening of potential crops. Section 4 describes the current cultivation of these crops and their yields. Section 5 assesses the potential for biofuel crops if grown under good management. Section 6 concludes.

\section{Land availability}

At regional level a number of limiting factors will determine land availability for biofuel production. These can be divided into biophysical limitations and human-determined limitations to production. To a certain extent some of the biophysical limitations to production can be overcome through management interventions such as irrigation and fertilization.

This study takes a regional overview of land availability. It in no way tries to determine whether a specific parcel of land is available, but rather looks at the large-scale determinants of suitability of land to produce crops. Most of the mapping is based on gridded data that has been developed through satellite imagery or modelling. The base data are mostly at around $1 \mathrm{~km}$ resolution or coarser, which means that microhabitats within the pixel may differ from the overall pixel, for instance due to small pockets of a different soil type. The approach should nevertheless give a good overview of regional suitability, provided that the constraints of the data are acknowledged.

The approach taken has been to identify areas where biofuel production is unlikely due to a range of constraints. It is assumed that all areas under conservation are automatically excluded. It is further suggested that areas with a high percentage of natural forest should be excluded. Finally, climatic and soil constraints are added. The combination of all the constraints forms a 'mask' that can be applied to crop production models to limit the modelled outputs to only those areas that are not subject to these major constraints. 
Any single constraint or combination of constraints can be removed if required, as all data are in a simple GIS format. For instance, if irrigation water is available, the rainfall constraint can be lifted.

\subsection{Biophysical limitations to biofuel production}

\section{Available precipitation}

Rainfall is a key determinant of the potential of an area to support high biomass production. The absolute amount of rainfall is a useful indicator of the water stress that plants are likely to experience, but there is also an interplay between rainfall, temperature, the duration of the rainy period, the seasonality of rainfall, soil factors, and sunshine hours that can affect this potential.

Annual rainfall below about $500 \mathrm{~mm}$ in tropical and subtropical environments is typically considered too little to support dryland agriculture. However, in the case of biofuel crops, high per hectare biomass yields must be obtained; therefore, substantially higher rainfall will be required to support biofuel crops. This will differ slightly between biodiesel crops and ethanol-based crops (or second-generation crops), as the biodiesel crops have a greater energy density and require smaller processing facilities, meaning that, even at relatively low yields, their viability for fuel might remain high.

It is clear from Figure 1a that the areas in Southern Africa with rainfall suitability for dryland biofuel crop production are largely to be found in Angola, Zambia, Mozambique, and Zimbabwe. Almost all of Namibia and Botswana, as well as large areas of South Africa, are too arid to be considered for dryland crop production. As a general rule, yields will increase with rainfall, at least until about 1,000-1,500 $\mathrm{mm}$ of rain. Very high rainfall may suppress yields due to waterlogging and problems with pests and diseases.

It is in the more arid areas where there is the greatest variability in rainfall (Figure 1b). This means that areas with already marginal production are the most likely to suffer drought conditions. Drought is an important consideration in the region. The regional rainfall is closely linked to ENSO cycles, with El Niño events typically resulting in severe drought that can affect the entire region. Any biofuel project would need to take into consideration the drought cycles. 
Figure 1: a) Mean annual precipitation; b) Variability in rainfall as the coefficient of variation (CV) calculated as the standard deviation over the mean
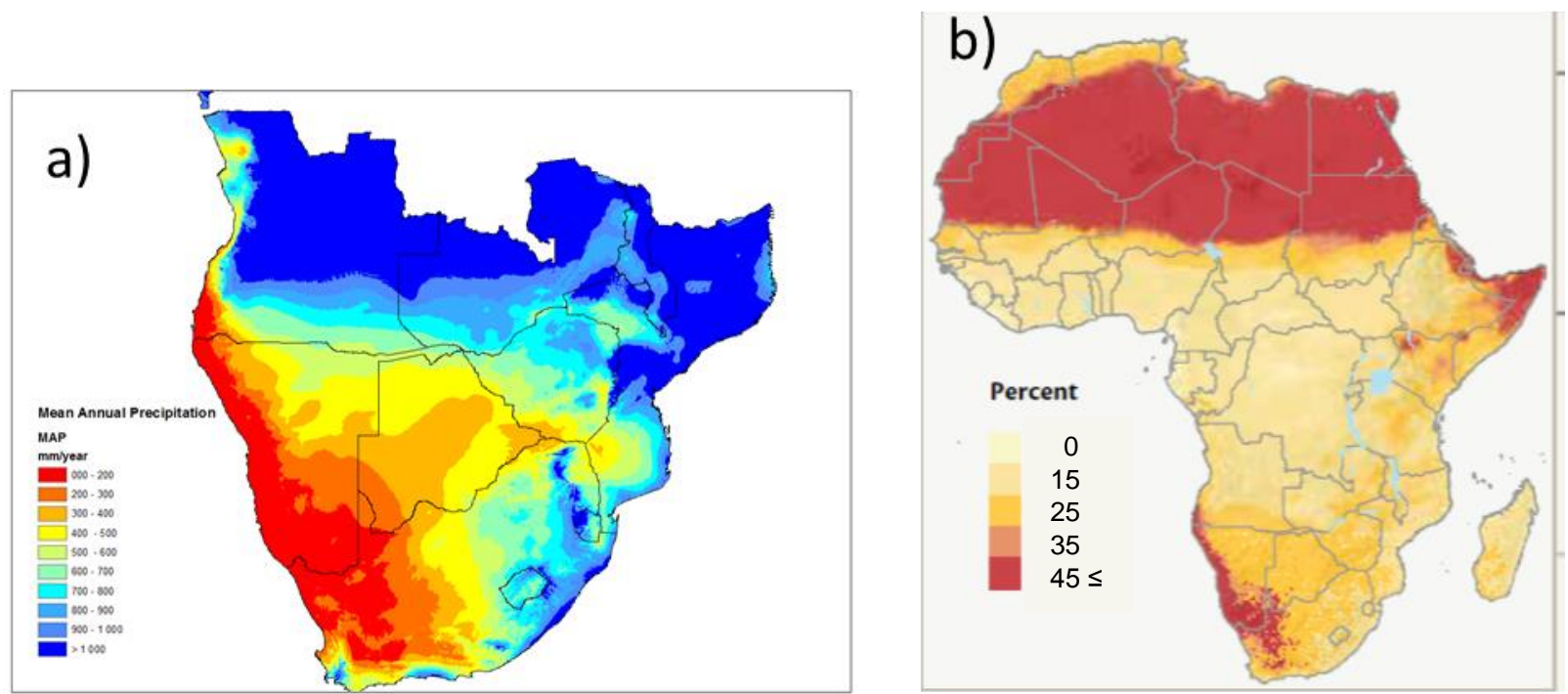

Note: b) Note the negative correlation with rainfall.

Sources: a) WorldClim 1.4 1961-1990 (data available at: http://worldclim.org); b) Sebastian (2014: map 2); reproduced with permission from the International Food Policy Research Institute.

One way of gaining a better understanding of potential plant water stress is to consider the ratio of rainfall to potential evaporation (Figure 2). This is referred to as the aridity index (AI), for which Middleton and Thomas (1997) defines aridity classes as per Figure 3. Although extensive dryland agriculture takes place in the upper bounds of the semi-arid class, it is likely that most biofuel crop production would be limited to sub-humid and humid areas, with the exception that some oilseed crops might be viable in semi-arid areas. Actual crop agriculture within the region is restricted to areas of above an aridity index of 0.20 (Figure 3). Reduced yields in areas with a high AI will be discussed under Soil parameters later. 
Figure 2: Current long-term (a) mean total precipitation and (b) potential evapotranspiration (PET) per month

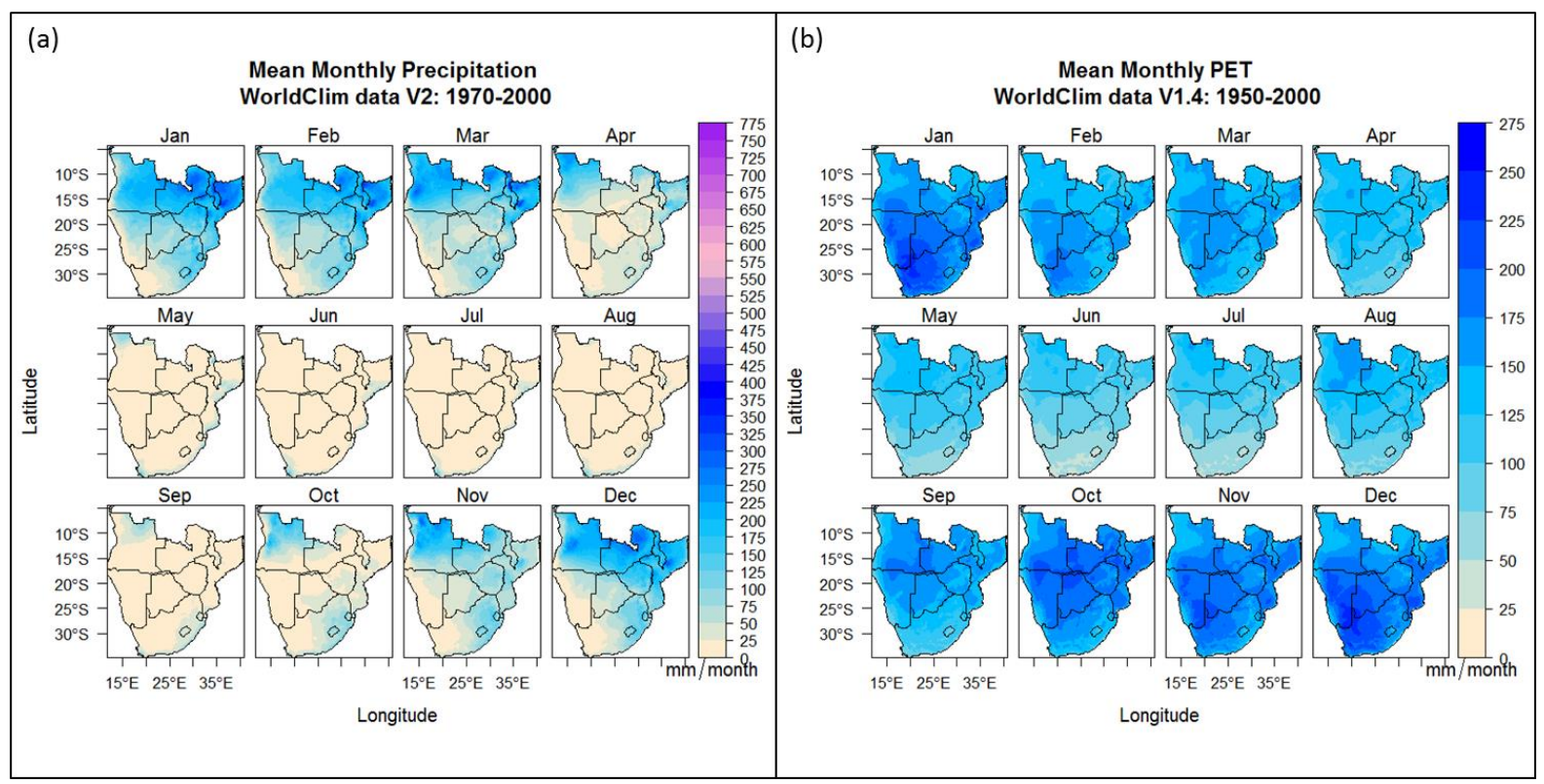

Notes: Precipitation data are for the period 1970-2000: monthly 30 seconds ( $1 \mathrm{~km}^{2}$ at the equator); the PET data are for 1950-2000 and are modelled using the WorldClim V1.4 dataset: monthly 30 seconds $\left(\sim 1 \mathrm{~km}^{2}\right.$ at the equator).

Sources: (a) WorldClim data V2 (spatial resolution; data available at: http://worldclim.org); (b) CGIAR-CSI GlobalAridity and Global-PET Geospatial Database (spatial resolution data available at: http://csi.cgiar.org/Aridity/).

Figure 3: a) Land cover classes by aridity map; b) Map of aridity index

a)

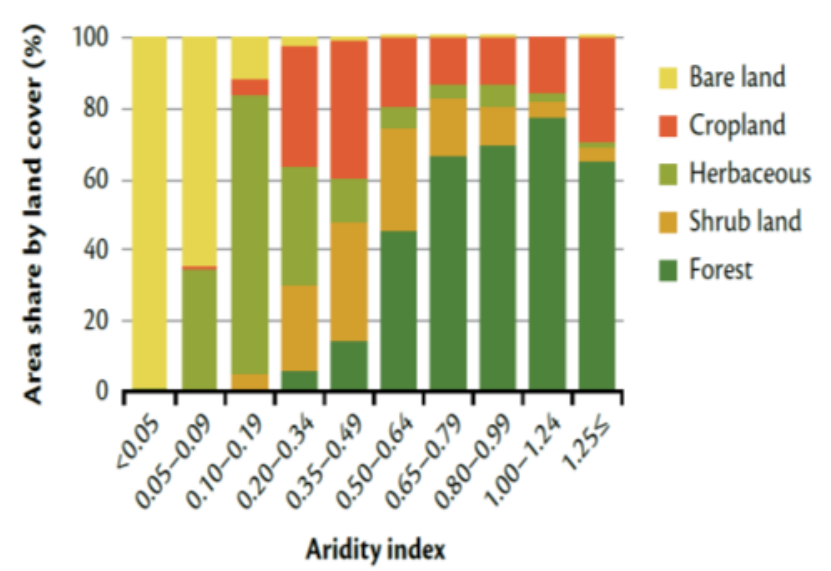

b)

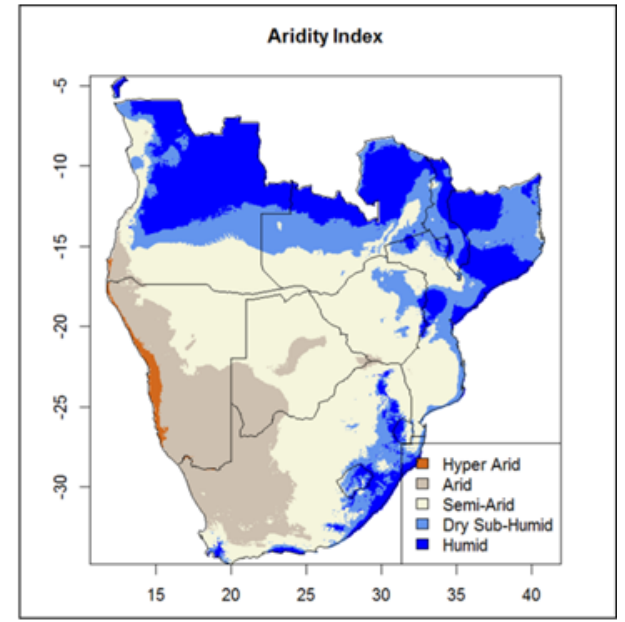

Source: Sebastian (2014: map 2), based on Trabucco and Zomer (2009).

A more complex estimation of soil water stress is provided in Figure 4, based on the methodology and data from Trabucco and Zomer (2010). This derives a monthly soil water balance (Figure 5) based on effective precipitation minus actual evapotranspiration minus runoff. This equation should give a reasonably accurate estimate of average monthly water stress that vegetation is likely to encounter. Figure 4 shows the mean monthly water stress, and monthly water stress data are given in Figure 5. The data highlight the fact that most of the area has a very strong seasonal pattern of rainfall, and that there is a long arid period in almost all areas except the east coast. The winter rainfall region of the Western Cape is also apparent. With the exception of some areas along 
the east coast, and the Western Cape, the area experiences a long dry winter. This has important impacts on crop selection. Perennial crops will either need to be able to withstand a long dry period, or need supplementary irrigation during the dry period. For annual crops, the duration of the growing season will be an important factor. Except in the potential frost areas, as discussed below and identified in Figure 6, soil moisture rather than temperature will be the main determinant of crop growth. The seasonality of rainfall and the uni-modal nature of the rainfall means that, with a few possible exceptions in Mozambique, only single-cropping cycles can be achieved per year (unless under irrigation).

Figure 4: Mean of annual monthly soil water balance

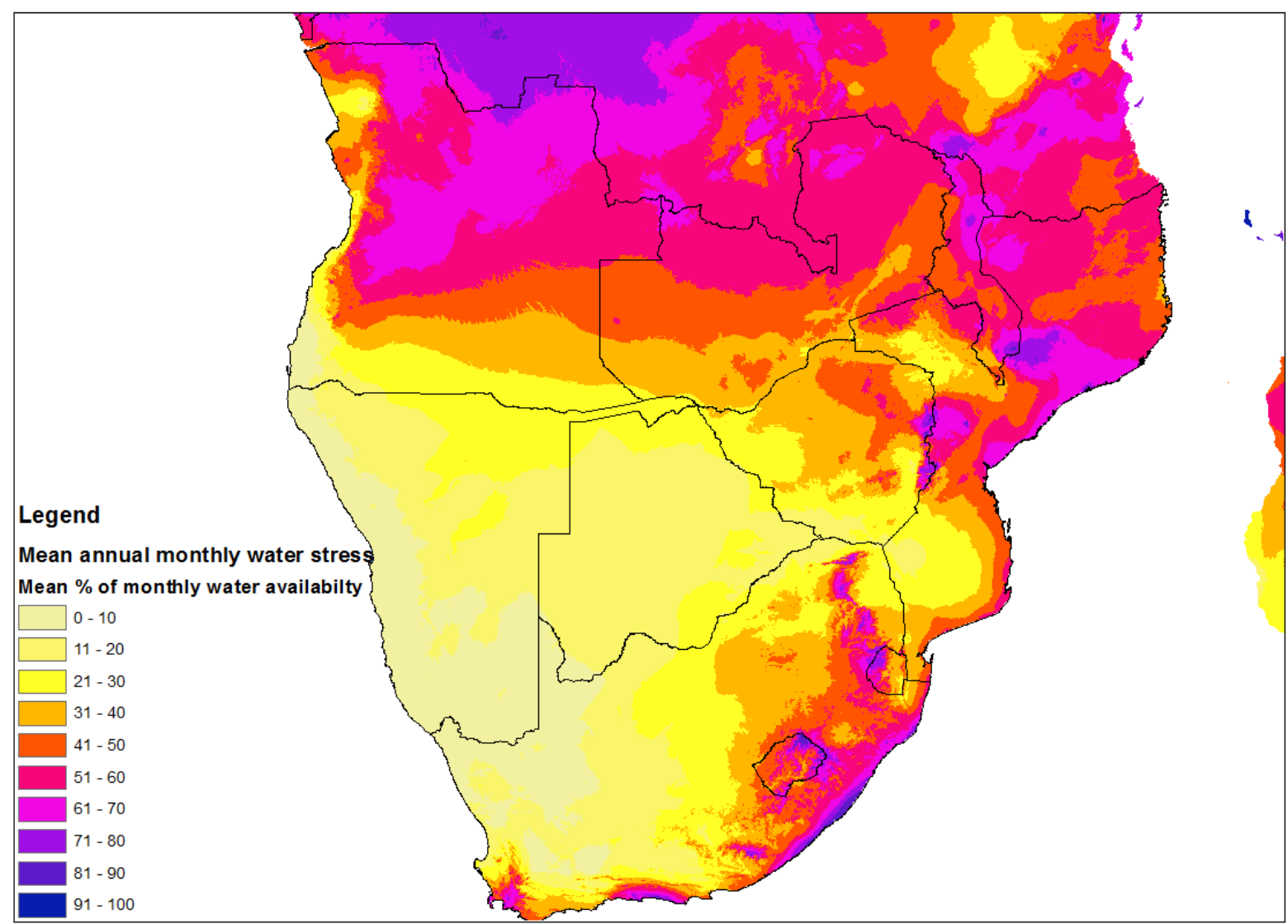

Source: Derived from Trabucco and Zomer (2010). 
Figure 5: Monthly soil water balance
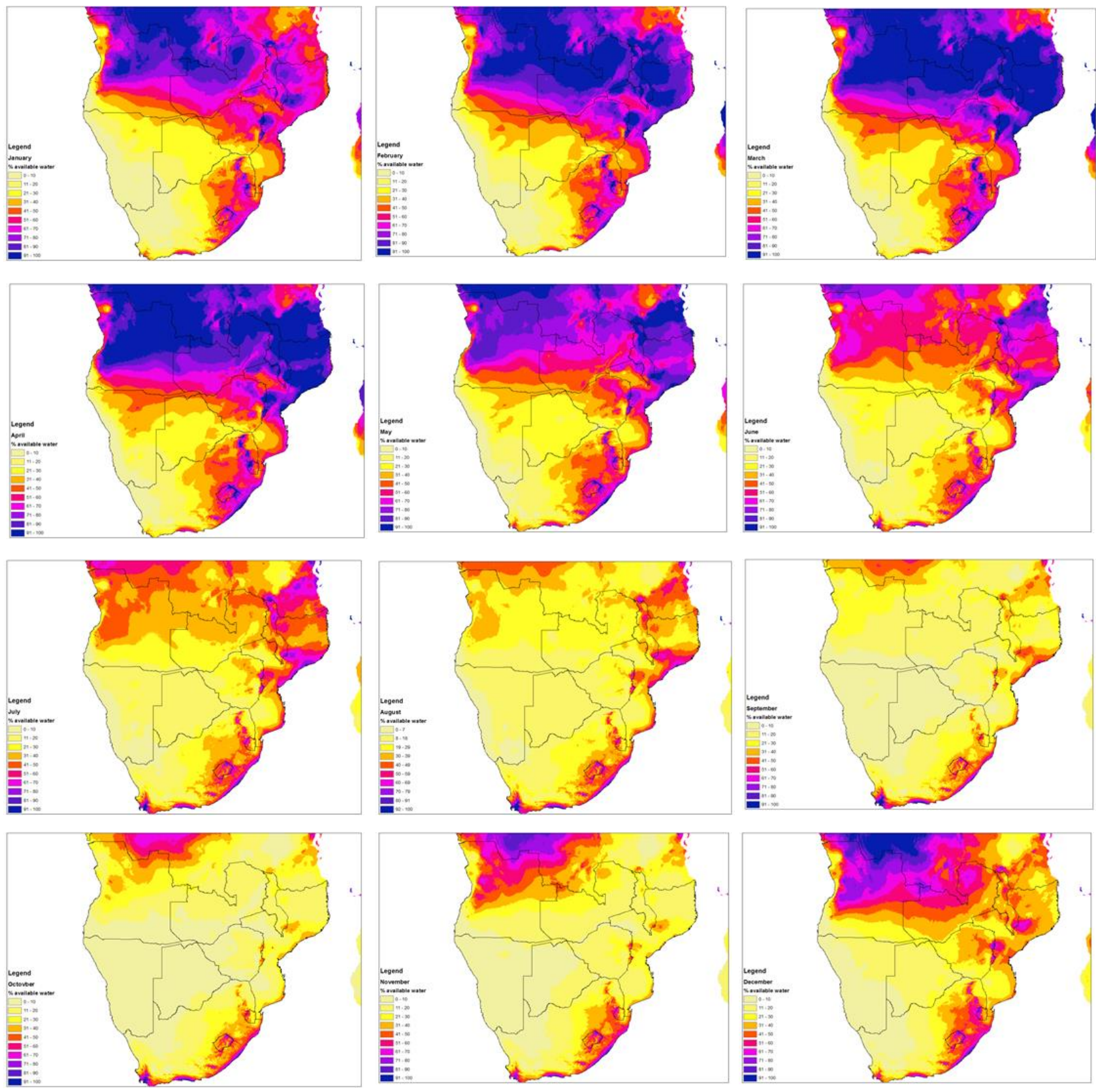

Source: Derived from Trabucco and Zomer (2010).

Temperature and sunshine

A key factor in plant growth is temperature. Although each plant species has a unique temperature response, in a generic sense, plants will start growing only in temperatures above zero degrees Celsius and there is a critical temperature above which photosynthesis will stop. $\mathrm{C}_{4}$ plants tend to be slightly more tolerant of extreme temperature than $\mathrm{C}_{3}$ plants, optimum temperatures for the latter being around $30^{\circ} \mathrm{C}$ compared with $35^{\circ} \mathrm{C}$ for $\mathrm{C}_{4}$ plants (Yamori et al. 2014). Enzyme activity stops above $45^{\circ} \mathrm{C}$ and hence all photosynthesis stops. These high temperatures are sometimes encountered in the hotter regions and are becoming more common due to climate change. Currently, however, it is water stress rather than heat stress that is more likely to inhibit plant growth in Southern Africa if the correct tropical and subtropical varieties are chosen. On the other hand, water stress is closely coupled to heat and it is the hotter areas that typically have the most 
water stress. For Southern African climates, $\mathrm{C}_{4}$ plants tend to have a production advantage over $\mathrm{C}_{3}$ plants, and from a biofuel perspective $\mathrm{C}_{4}$ plants will typically be the plants that produce the most biomass.

Figure 6: Mean maximum January temperatures

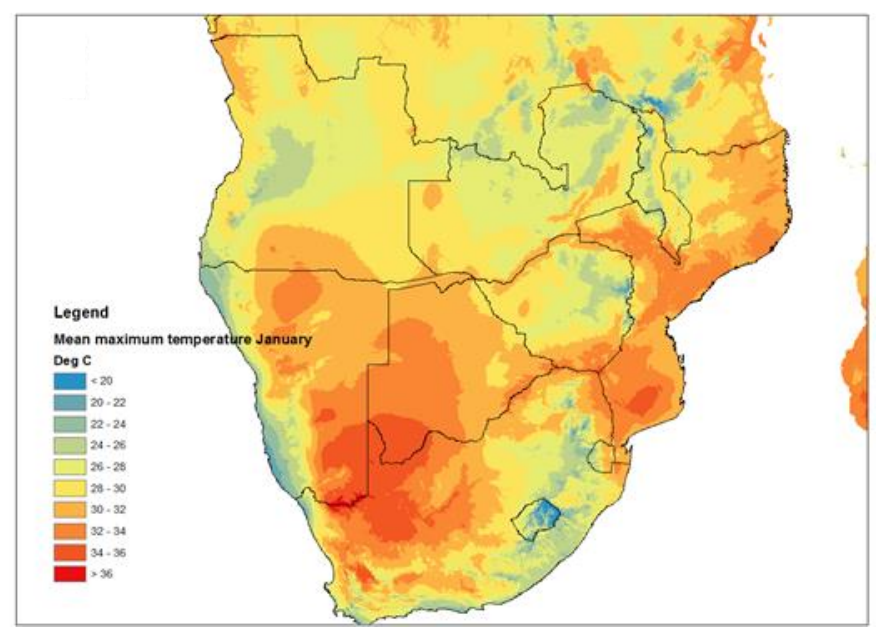

Sources: Based on WorldClim 1.4 data (data available at: http://worldclim.org).

Figure $6 \mathrm{~b}$ shows mean monthly maximum temperatures for January (typically the hottest month in the region). The arid Kalahari area is one of the hottest areas, along with low-lying areas along the east coast and the arid river valleys of the Limpopo and Zambezi River.

Low temperatures, and especially the occurrence of frost, can limit the growth of many crops and/or limit the duration of the growing season for a crop. Accurate maps of frost are difficult to produce, as frost can be highly localized, but minimum temperatures in the coldest month give a good approximation of frost areas. As can be seen from Figure 7a, the interior of South Africa, as well as southern parts of Botswana and Namibia and all of Lesotho, have temperatures approaching or below zero at night in winter. The east coast and northern regions have far milder winters, many areas being suited to tropical and subtropical crops. 
Figure 7: a) Mean minimum temperatures in June; b) Mean annual temperatures for 1961-1990

a)

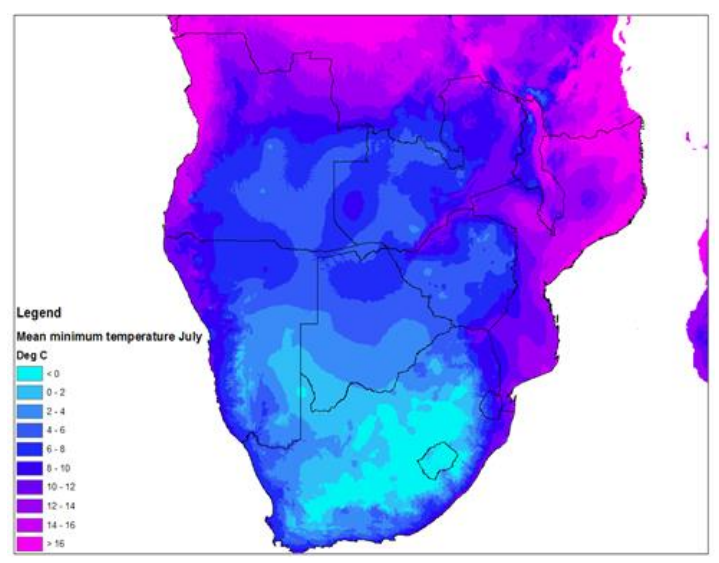

b)

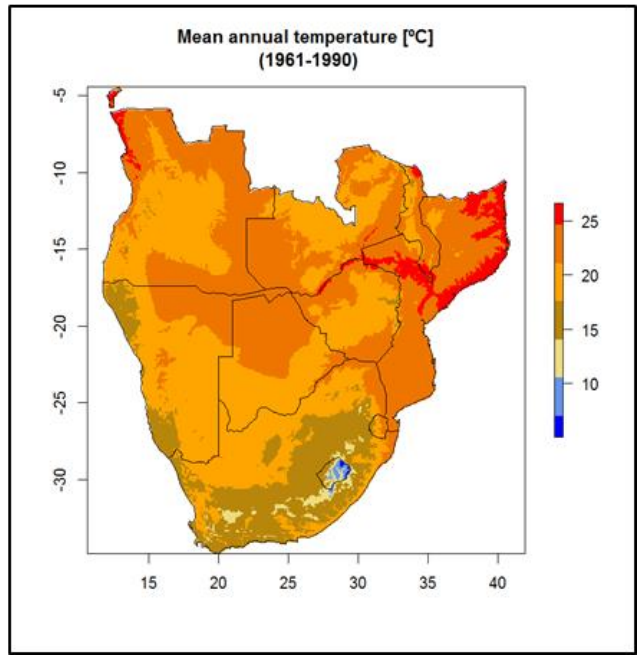

Sources: a) Based on WorldClim 1.4 data (data available at: http://worldclim.org); b) IIASA/FAO (2012) (available at: http://gaez.fao.org/).

Many plant models base plant growth on accumulated heat units over the growing season, and insufficient heat units within the growing season can limit plants' ability to mature. For most of the Southern African region, lack of moisture is a more serious constraint than lack of heat. However, where irrigation is available, heat units can be a good indicator of growing conditions, yield, and time to crop maturity. For all but the central area of South Africa (the two coldest classes in Figure $7 \mathrm{a}$ ), lack of heat units is seldom a major constraint. Figure $7 \mathrm{~b}$ shows mean annual temperature. As can be seen, much of the area, except high areas in South Africa, have a mean temperature above $20^{\circ} \mathrm{C}$, with subtropical high temperatures common on the east coast. It should be noted that high mean temperatures tend to be further north than areas with high maximum temperatures. This is because the areas with the high maximum temperatures are mostly arid and experience cold nights, often with extreme day to night temperature ranges.

Solar radiation in the region is primarily limited by cloud cover, and it is the more arid areas that tend to have the highest irradiation (Figure 8). Given the high irradiation and high daytime temperatures in these areas, there is good potential for irrigated crops (in the few areas where irrigation is possible), though much of the area with the highest irradiation is susceptible to frost, which limits the growth season. 
Figure 8: Average annual sunshine

\section{Direct Normal Irradiation} Africa and Middle East

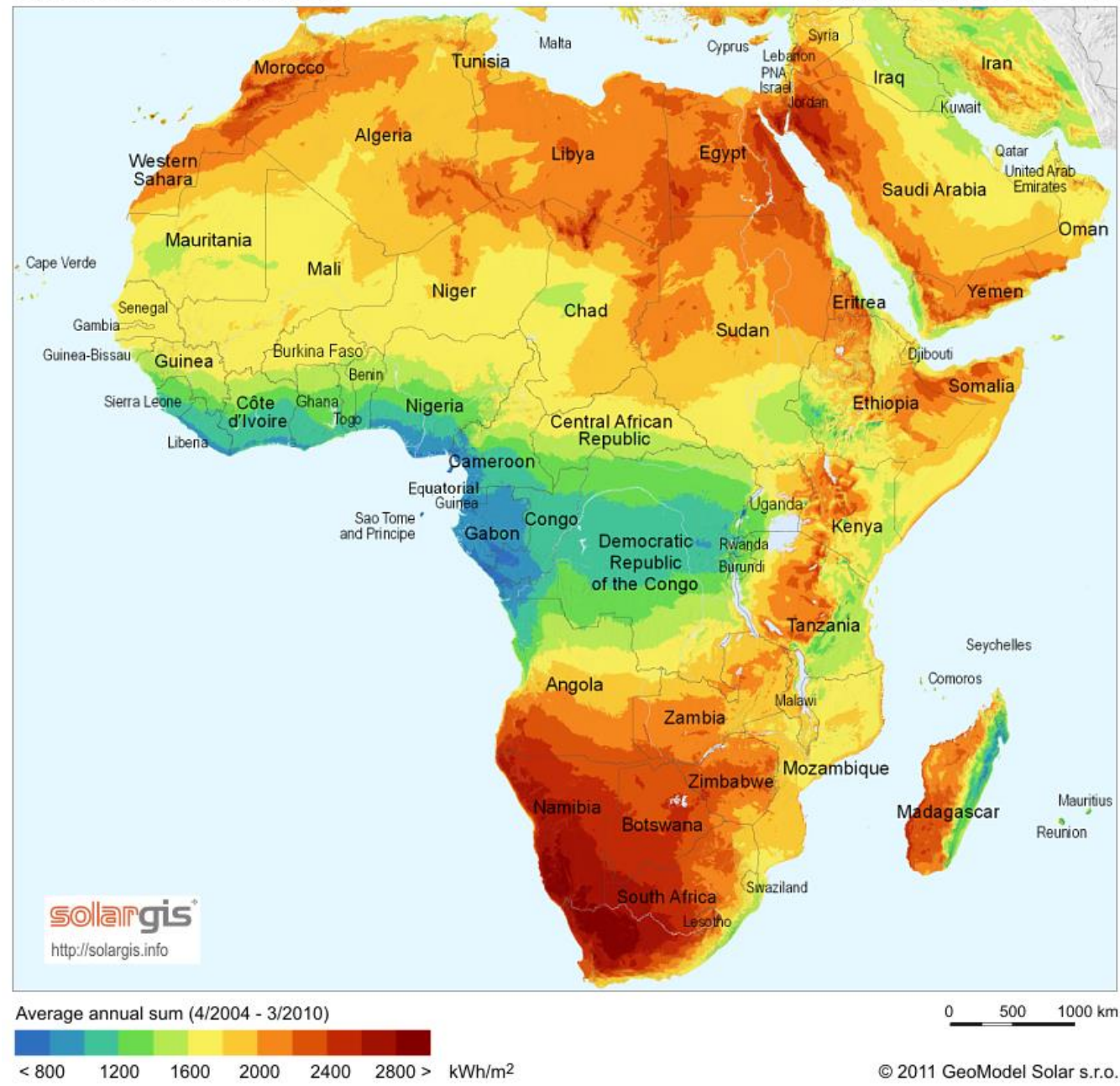

Source: Solargis (data available at: http://solargis.com/products/maps-and-gis-data/free/overview/).

\section{Soil parameters}

Although much of the region is undulating, only a relatively small area is dominated by steep slopes (Figure 9). A slope of 16 per cent or greater is likely to limit large-scale production of annual crops, but may still be suited to perennial biofuel crops such as short-rotation or conventional forestry species. It should be noted that large areas of South Africa, especially along the east coast, that have favourable climatic conditions for cropping are areas that may be excluded on account of excessive slope. 
Figure 9: Percentage area of a pixel area with a slope less or more than $16 \%$

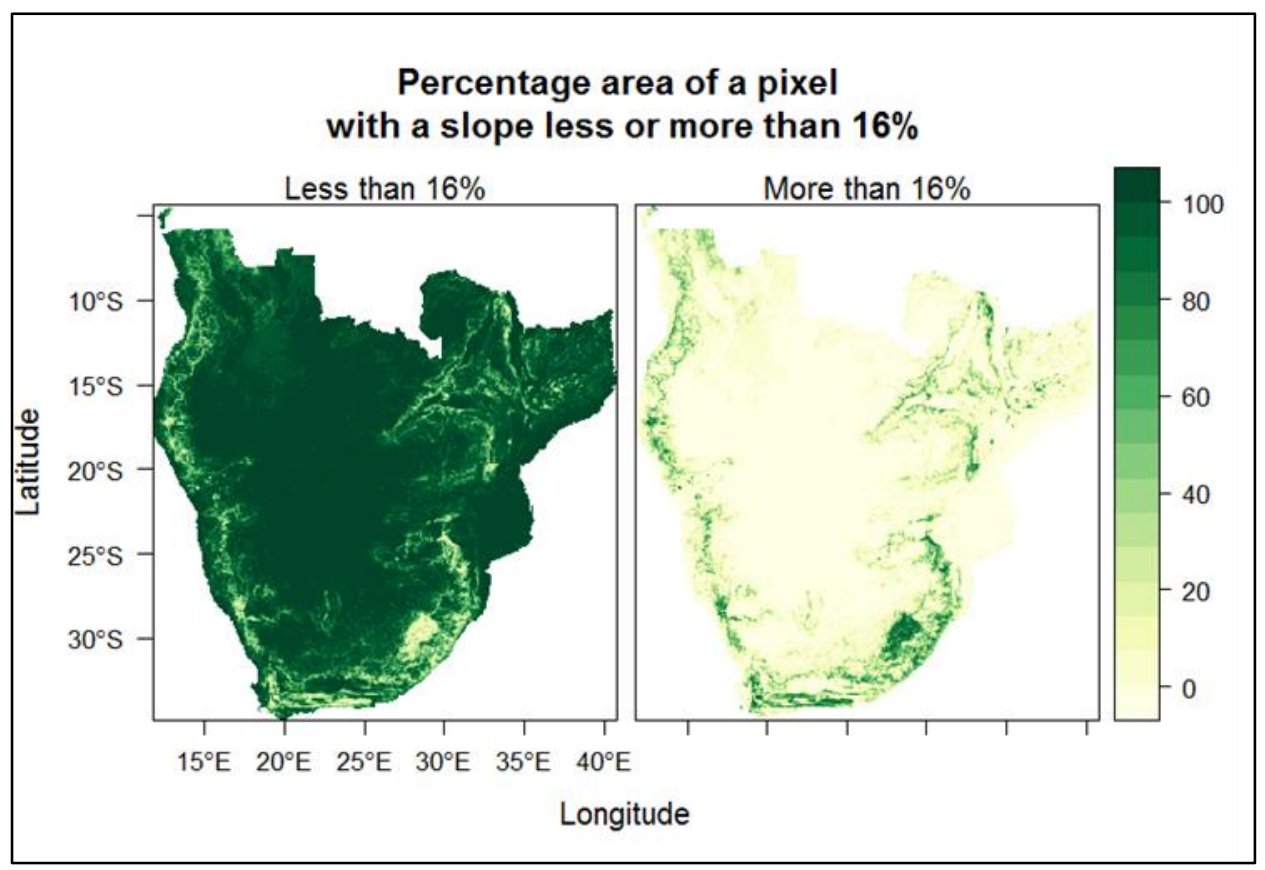

Note: A maximum slope value of $16 \%$ is considered suitable for cropping.

Source: IIASA/FAO (2012) (available at: http://gaez.fao.org/).

An overview of a few soil parameters of importance to plant growth is given in Figure 10. These are from the Harmonized World Soil Database (Fischer et al. 2008). For regional crop modelling, the more recent AfSIS soil database (http://africasoils.net/services/data/digital-soil-mapping/) may be a better data source. However, for any project implementation, actual site-specific soil data would be needed and it is possible that these may differ substantially from the regional assessments. For instance, though a region may be mapped as having sandy soils at the scale of the databases, at a local scale there can be distinct catena differences in soil, with deep sands on ridge tops and heavy clays in valley bottoms. This pattern is common over much of the miombo region. This will mean that at the local scale sugarcane or cotton may be most appropriate on the clays, whilst jatropha may be better suited to the sands.

Most of Southern Africa's soils are old and leached, and in many cases have low fertility and high aluminium toxicity, soils of the FAO classes ferralsols, luvisols, lixisols, and acrisols being the main soil classes in northern Mozambique and Zambia (Figure 11). In most cases these soils will require extensive liming and high fertilizer inputs to be productive; they are known to be difficult to manage, and extensive care is needed in their management. However, with the correct inputs they can be productive soils. 
Figure 10: Main soil classes (FAO) as per the Harmonized World Soil Database

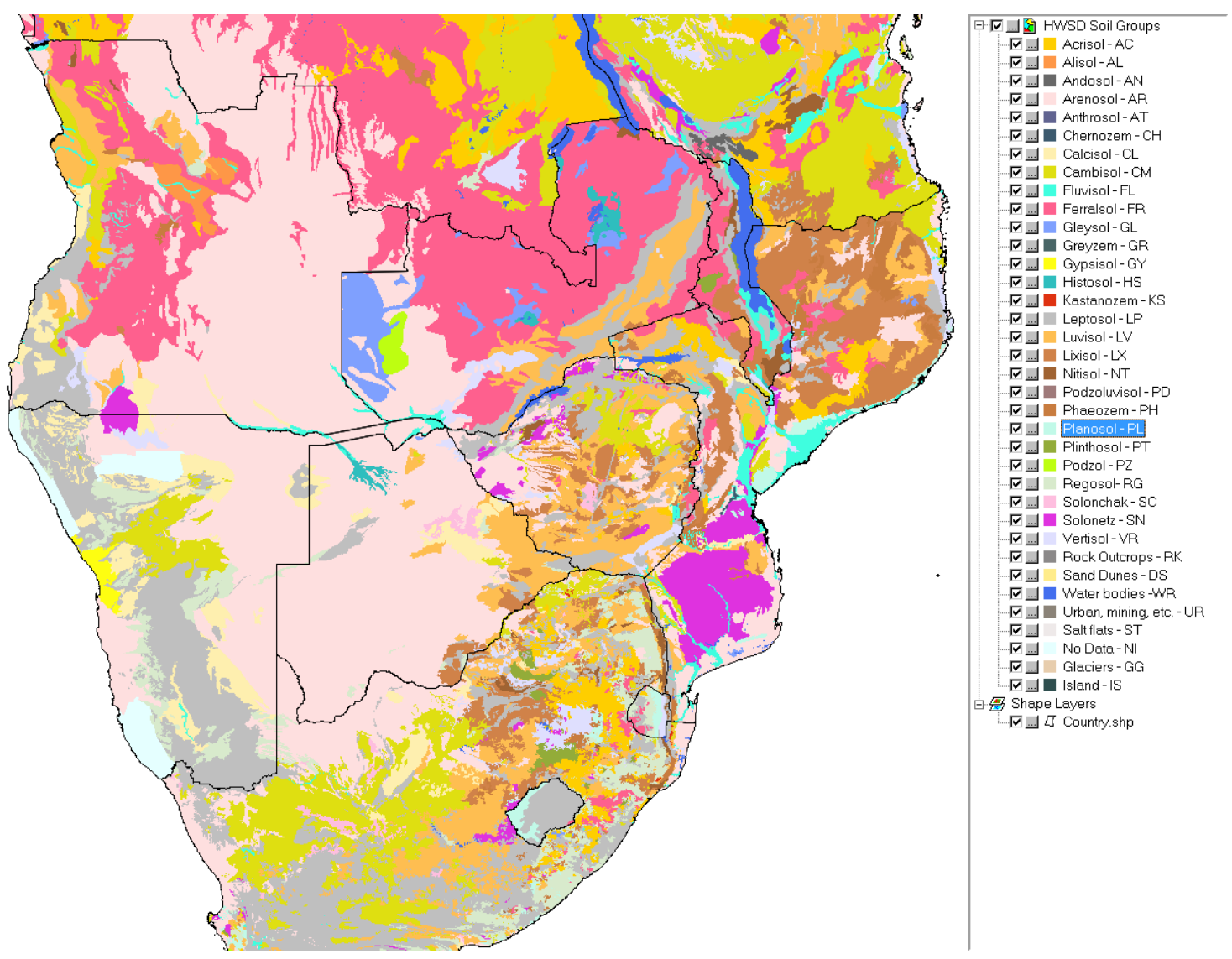

Source: Fischer et al. (2008).

As can be seen from Figure 11a, vast areas of the sub-region are dominated by sands. This includes the extensive Kalahari sands that stretch from South Africa into Angola and include most of Botswana. In addition, much of Mozambique is sandy, as are large areas of Zambia. Sandy soils tend to have low nutrient content and low nutrient-holding capacity, and are easily leached in areas of high rainfall.

Sandy soils are also poor at building up large soil carbon stocks, and their low soil carbon has a negative impact on soil nutrients and soil nutrient-holding capacity. Soils with high carbon tend to be nutrient rich and good for cultivation (Figure 11e).

Although few areas are classified as heavy clay at the resolution of the mapping, at the local level catena bottoms are often dominated by clay soils (Figure 11b). These soils can be ideal for some crops, but working them is more difficult and they can become impassable to vehicles when wet.

Soil depth is mostly a limiting feature in the karoo region of South Africa and parts of Namibia, both regions being too arid for agriculture. It is also a limiting factor in many of the mountainous areas - areas that are also excluded from annual cropping due to slope (Figure 11c).

Gravel can impede management functions such as ploughing, but a high proportion of gravel in the topsoil is a relatively uncommon feature of the Southern African landscape, occurring mostly in areas that would be excluded from cropping on the basis of shallow soil or slope (Figure 11d). 
Figure 11: Percentage of topsoil that is a) sand and b) clay; c) Depth to bedrock; d) Proportion of gravel; e) Soil organic carbon in the topsoil

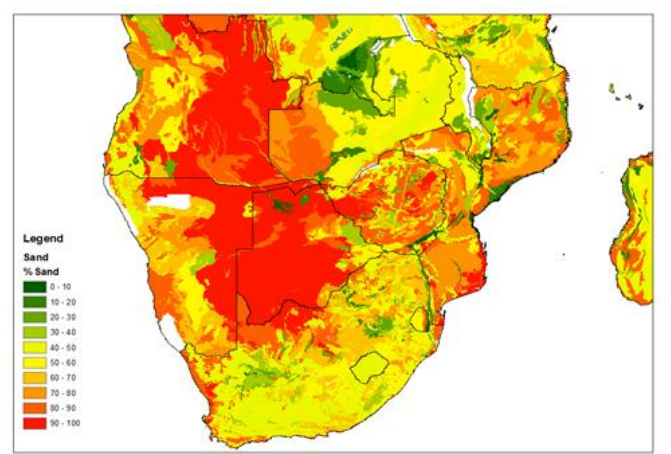

a) Sand

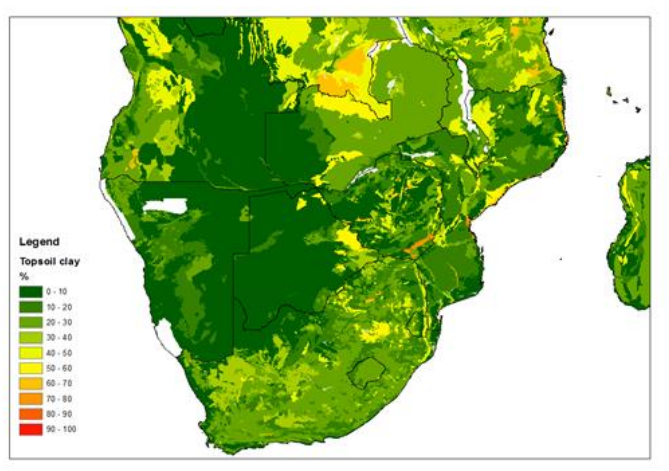

b) Clay

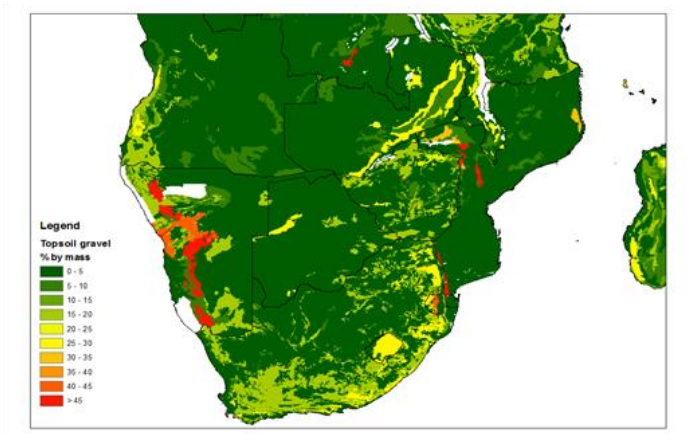

d) Gravel

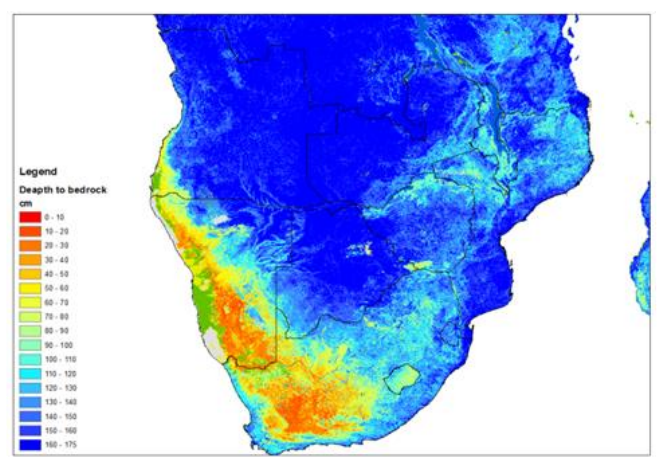

c) Depth to bedrock

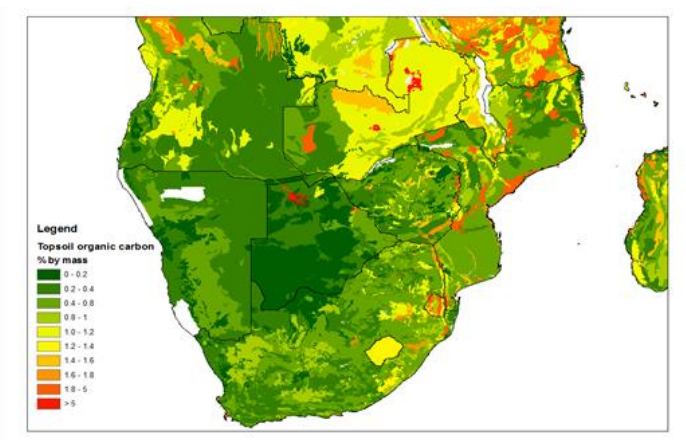

e) Organic carbon

Sources: a) and b) Fischer et al 2008); c) AfSIS database (data available at: africasoils.net/); d) and e) Fischer et al. (2008).

The Harmonized World Soil Database (HWSD) defines seven categories of soil limitations (Table 1). ${ }^{1}$ These data are shown in Figure $12 \mathrm{a}-\mathrm{g}$. Figure $12 \mathrm{~h}$ shows the number of limiting factors. 'Severe limitations or worse' was used for all limiting factors except 'nutrient retention' and 'nutrient availability', where 'very severe' was required for inclusion as a limiting factor.

\footnotetext{
1 These are described in detail at: http://webarchive.iiasa.ac.at/Research/LUC/External-World-soil-
} database/HTML/SoilQuality.html?sb=10 and in Fischer et al. (2008). 
Table 1: Soil characteristics

\begin{tabular}{|c|c|c|}
\hline & Soil qualities & Soil characteristics \\
\hline 1 & Nutrient availability & Soil texture, soil organic carbon, soil pH, total exchangeable bases \\
\hline 2 & Nutrient retention capacity & $\begin{array}{l}\text { Soil organic carbon, soil texture, base saturation, cation exchange } \\
\text { capacity of soil and of clay fraction }\end{array}$ \\
\hline 3 & Rooting conditions & $\begin{array}{l}\text { Soil textures, bulk density, coarse fragments, vertic soil properties } \\
\text { and soil phases affecting root penetration, soil depth, and soil } \\
\text { volume }\end{array}$ \\
\hline 4 & Oxygen availability to roots & Soil drainage and soil phases affecting soil drainage \\
\hline 5 & Excess salts & $\begin{array}{l}\text { Soil salinity, soil sodicity, and soil phases influencing salt } \\
\text { conditions }\end{array}$ \\
\hline 6 & Toxicity & Calcium carbonate and gypsum \\
\hline 7 & $\begin{array}{l}\text { Workability (constraining field } \\
\text { management) }\end{array}$ & $\begin{array}{l}\text { Soil texture, effective soil depth/volume, and soil phases } \\
\text { constraining soil management (soil depth, rock outcrop, stoniness, } \\
\text { gravel/concretions, and hardpans) }\end{array}$ \\
\hline
\end{tabular}

Source: Harmonized World Soil Database v 1.2 (available at: http://www.fao.org/soils-portal/soil-survey/soilmaps-and-databases/harmonized-world-soil-database-v12/en/). 
Figure 12: a) Soil nutrient availability; b) Nutrient retention capacity; c) Rooting conditions; d) Oxygen availability to roots; e) Excess salts; f) Calcium carbonate and gypsum toxicity; g) Workability; h) Total number of soil constraints

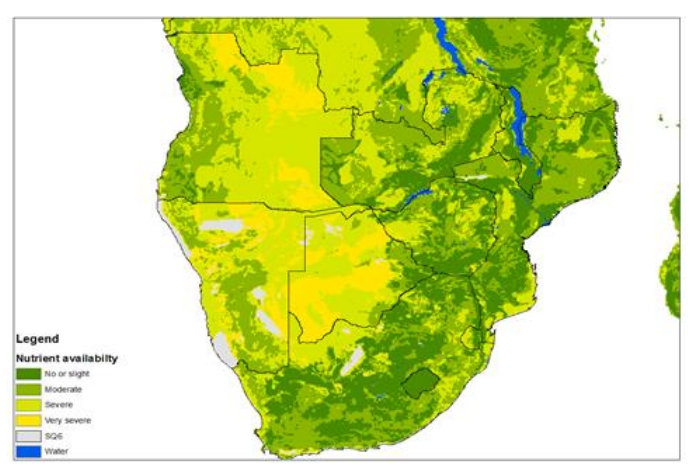

a) Nutrient availability

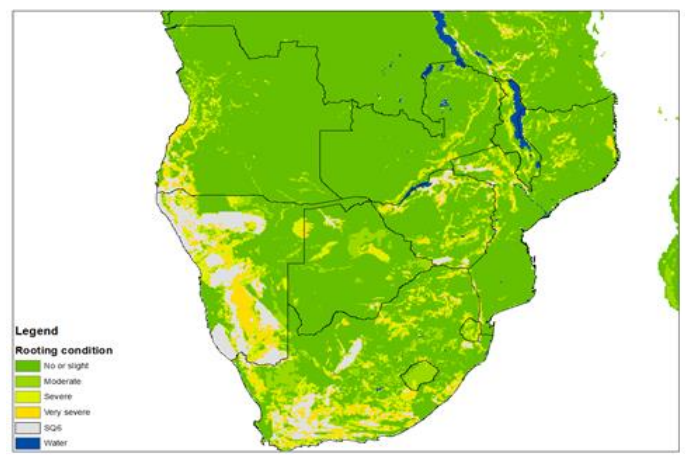

c) Rooting conditions

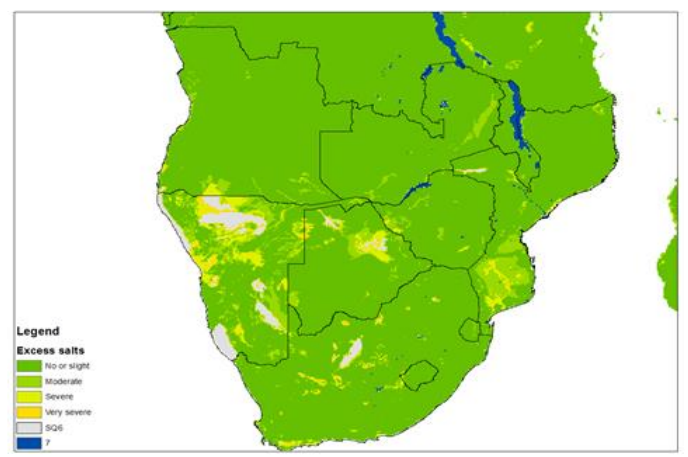

e) Excess salts

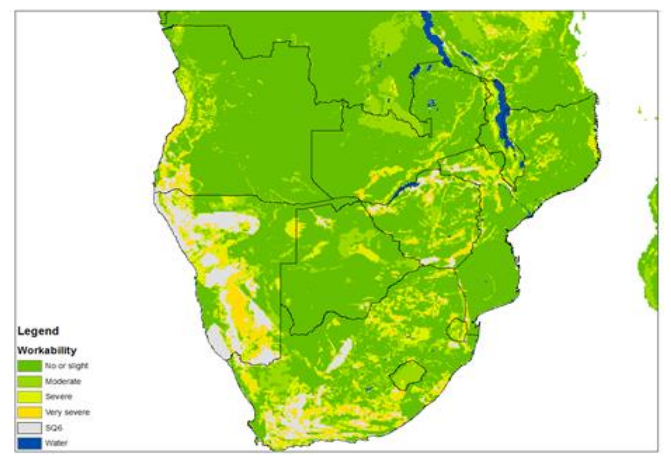

g) Soil workability

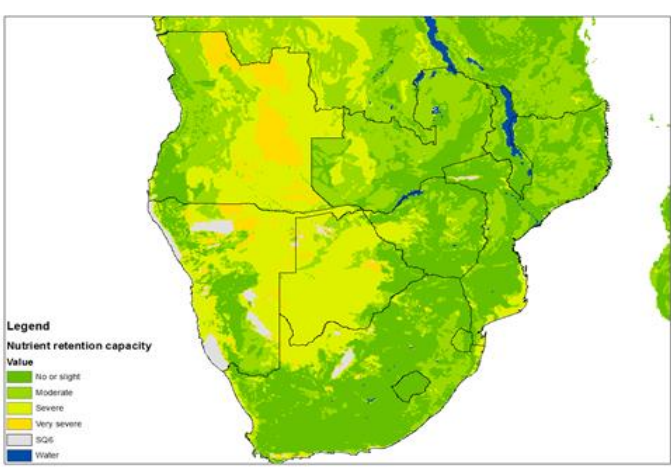

b) Nutrient retention

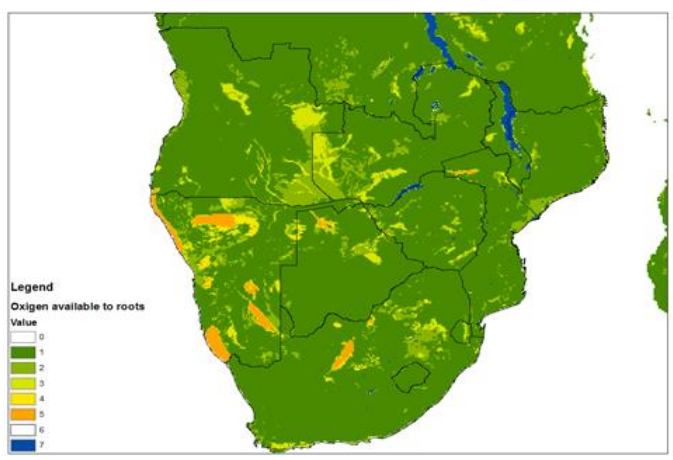

d) Oxygen availability

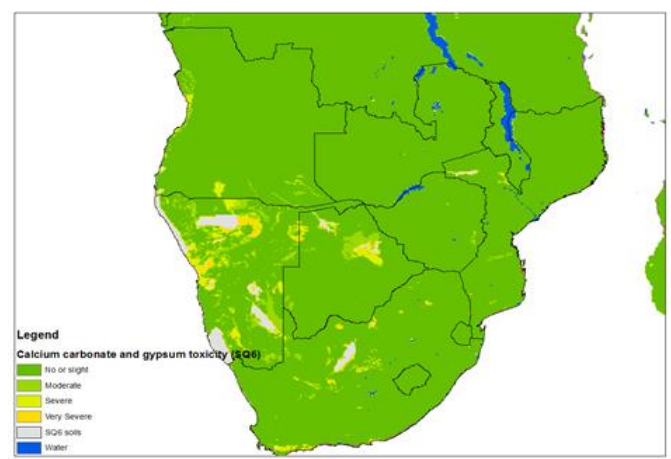

f) Gypsum toxicity

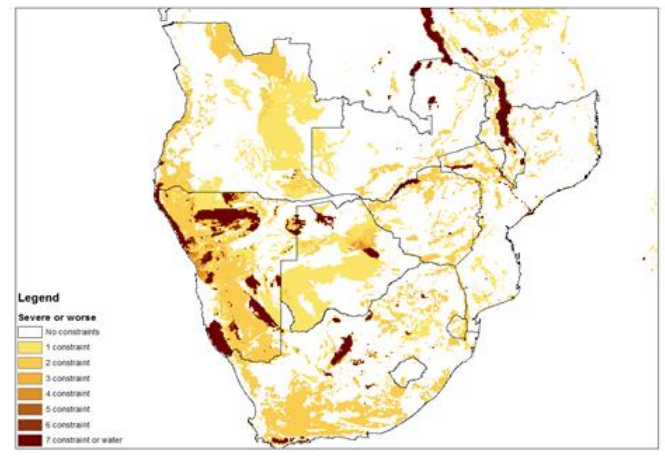

h) Number of constraints

Source: Fischer et al. (2008). 
The extensive deep sands in Southern Africa have especially low nutrient availability, especially in the high-rainfall areas, as nutrients are easily leached from the sands. The clearly discernible 'fenceline' contrast between Angola and Zambia (seen in the Figure 12 maps) is probably a function of different soil classification systems being used in the two countries rather than a true difference. With the exception of the Kalahari sands, large areas of the sub-region have only slight or moderate nutrient availability constraints. However, many areas that score well on most other soil and climatic parameters, such as Northern Zambia and parts of Zimbabwe and South Africa, have severe soil nutrient constraints. This is a function of geology and because the soils are ancient and in some cases highly leached. Managing soil nutrient constraints is likely to be one of the single biggest challenges for biofuel production in much of the region. Since soil nutrients are closely linked to soil organic matter and plant nutrient cycling, both the vegetation and soil carbon need to be carefully managed. Fertilization will be a key requirement for sustainable biofuel production, and due to the nature of the soils this might be a greater expense than the international norm.

Soil nutrient retention capacity (Figure 12b) is linked to many of the same drivers as soil nutrient status, and the same management cautions apply. Building and maintaining high soil carbon and soil organic matter will be important. Soil liming may be a critical intervention in many areas, but this can also have adverse impacts on plant access to micro-nutrients. The integrated map of rooting conditions (Figure 12c) integrates many aspects already highlighted, such as soil texture and rooting depth. The amount of oxygen available to roots is affected when soils are waterlogged. This may be a constraint in south-western Zambia and the adjacent area in Angola. For most other areas identified with good potential, waterlogging appears to be a relatively minor problem (Figure $12 \mathrm{~d})$.

Excessive salts (Figure 12e) is largely a problem limited to arid areas, and in particular the large salt pans of Botswana and Namibia. It is therefore more a localized than a widespread problem in the region. Calcium carbonate and gypsum toxicity is not seen as a constraint except in some of the areas that are too arid for cropping at any rate (Figure 12f). Soil workability (Figure 12g) is not identified as a major constraint in the region, other than in areas of shallow soils and in mountainous areas, as already identified. Figure $12 \mathrm{~h}$ shows all the areas experiencing one or more soil constraints.

\subsection{Human-determined limitations to biofuel production}

\section{Protected areas}

The Southern Africa region has a large percentage of formally protected areas, and less formally protected areas used for eco-tourism and hunting. The nature of these regions differs per country, each country having unique conservation legislation. This is summarized in a simplified version of data from the United Nations Environment Programme (UNEP) World Database of Protected Areas (WDPA: https://www.protectedplanet.net/) (Figure 13). With the exception of biosphere reserves, which allow agriculture in buffer areas, it is likely that biofuel production would not be possible in any of these areas. 
Figure 13: Protected areas in Southern Africa

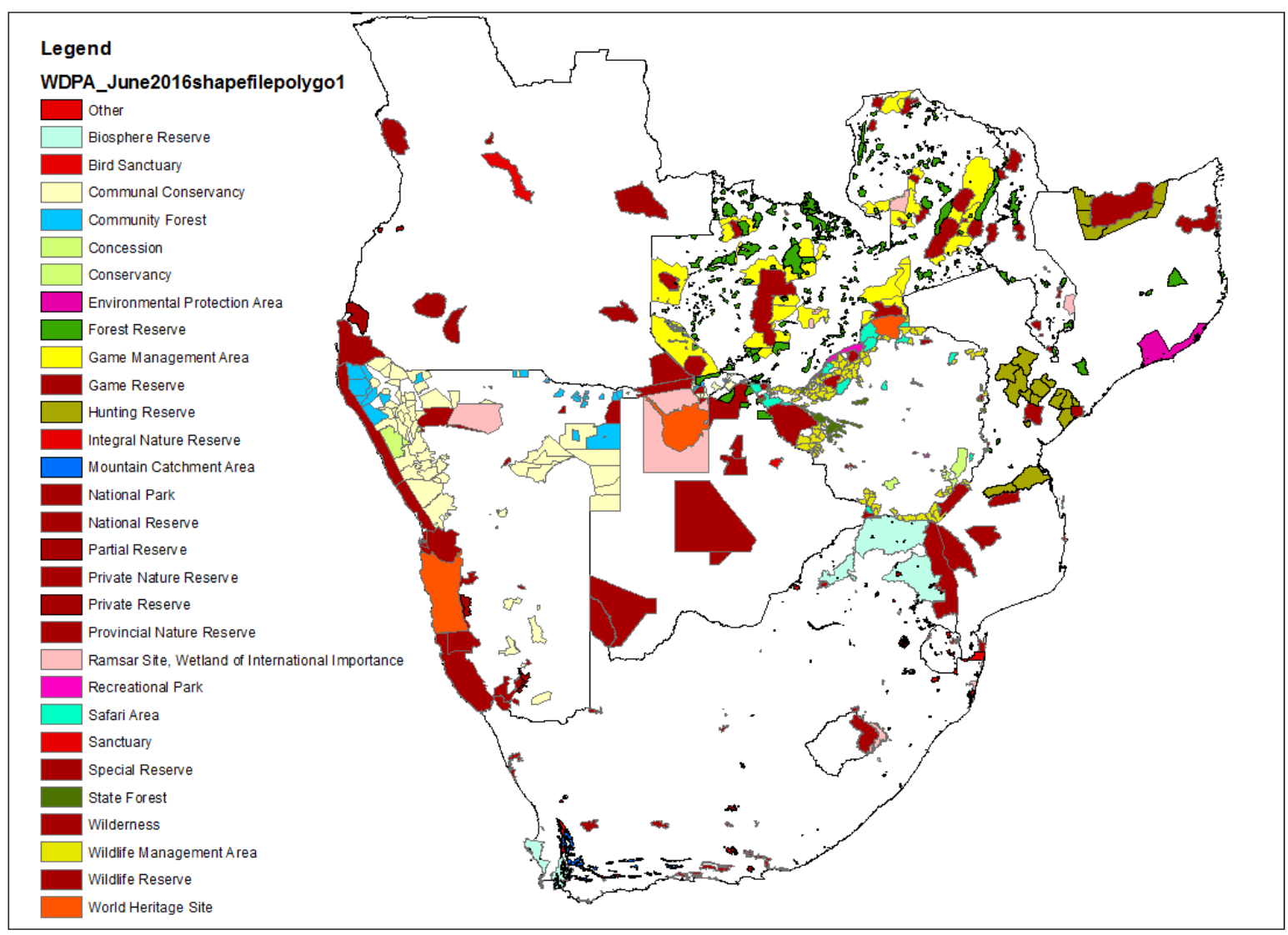

Note: Colour coding has been used to group areas with similar conservation status. However, since different legislation, naming conventions, and definitions apply per country, this can only be an approximate classification.

Source: WDPA.

Many areas that are not formal conservation areas are forest. Figure 14 gives the percentage of forest cover per cell. Clearing of primary forest for biofuel should be avoided, and would make the biofuel invalid for the claiming of carbon credits in places such as the EU. However, much of the forest may be secondary or degraded and in such cases biofuel may be an option. Detailed maps of forest states are hard to obtain and projects would need to be case-specific. The fact that a pixel is not 100 per cent forest is also not an indication of degradation. Grassland patches (termed dambos in Zambia) are a common and natural feature of miombo forest. 
Figure 14: Percentage of each grid cell that is forest

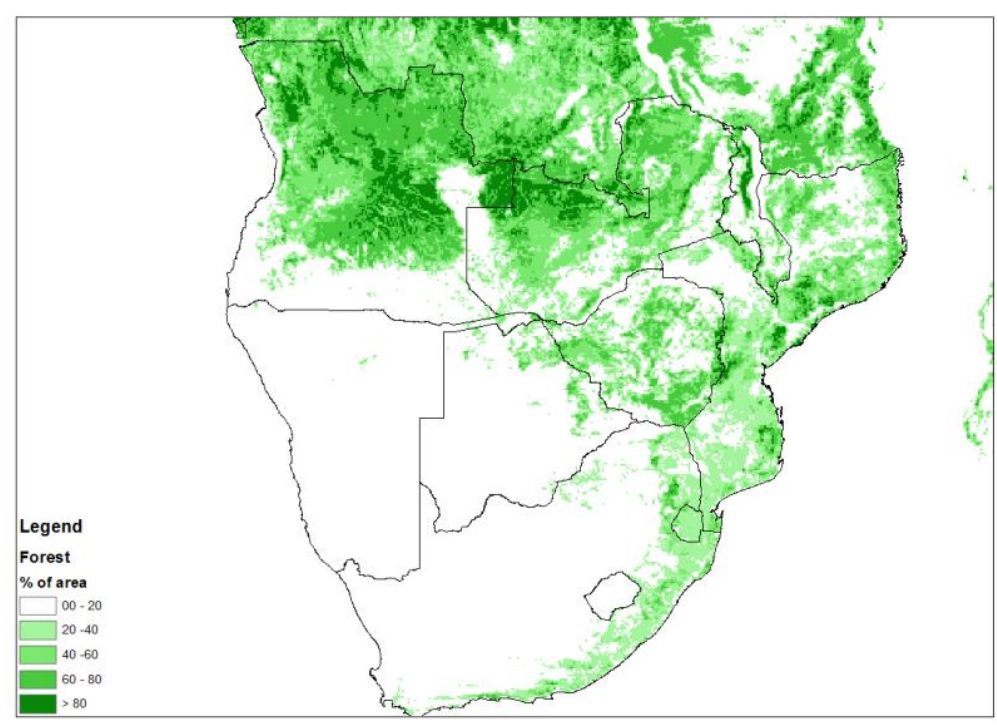

Source: FAO (2001).

Human constraints should also be considered when deciding on areas for biofuel production. Figure 15a indicates population density across the region. Areas such as Malawi have exceptionally high population density, meaning that it will be difficult to find available land that is not already being used. Much of Mozambique and Zambia has low rural population density. The density of livestock (Figure 15b) is also an indication of the intensity of alternative land use. Travel time to large cities (Figure 16) gives an indication of the isolation of areas.

Figure 15: (a) Human population density for the year 2000 (number of persons $/ \mathrm{km}^{2}$ ); (b) Ruminant livestock density for the year 2000 (number of TLUs $/ \mathrm{km}^{2}$ )

(a) Human population density [\#persons/km2]

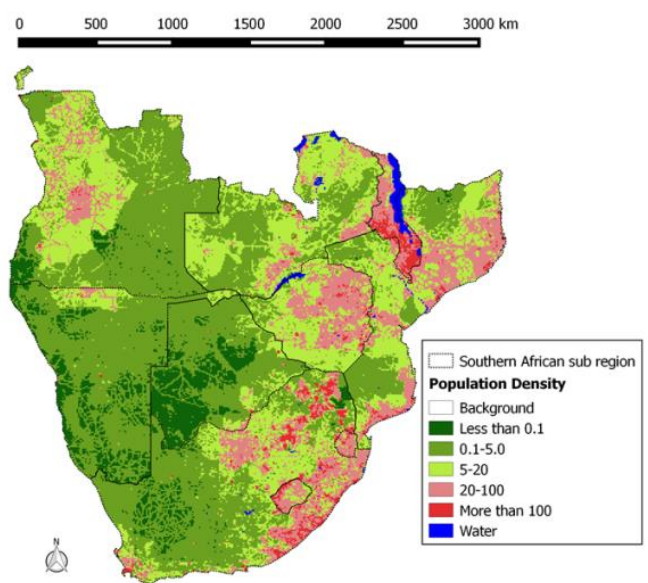

(b) Livestock density [\#TLUs/km2]

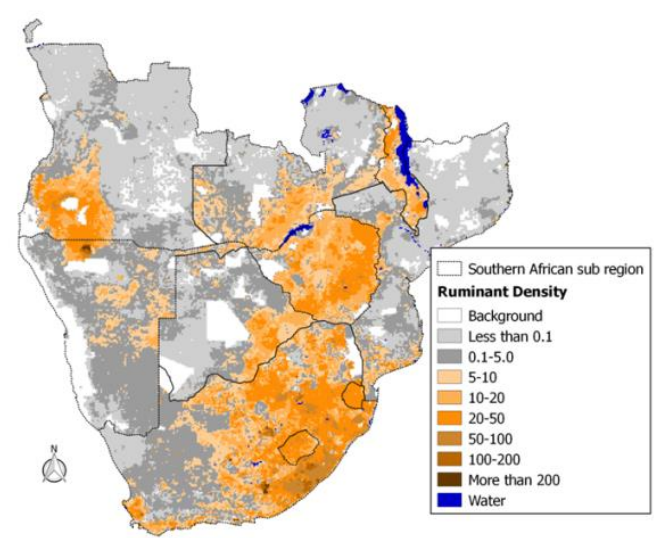

TLU - Tropical Livestock Units: 1 TLU has an equivalent live weight of $250 \mathrm{~kg}$.

Source: IIASA/FAO (2012) (available at: http://gaez.fao.org/). 
Figure 16: Mean travel time per grid cell (hr) to the nearest ports for the year 2000

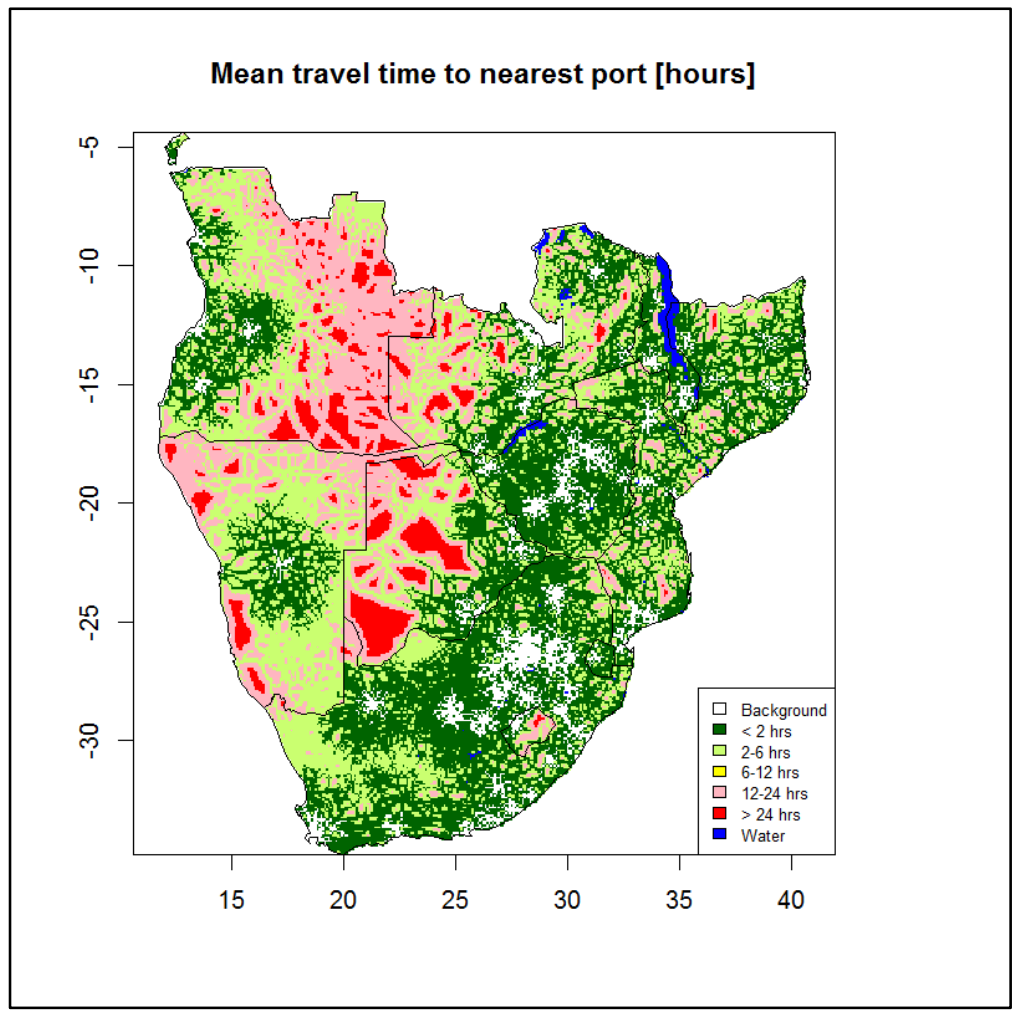

Note: The legend classes are from the GAEZ dataset.

Sources: HarvestChoice (2015); IIASA/FAO (2012) (available at: http://gaez.fao.org/).

Irrigation infrastructure is relatively limited in the region. Figure 17 gives a spatial overview of the area equipped with irrigation infrastructure. Appendix 1 summarizes water usage from existing irrigation infrastructure by country. 
Figure 17: Area equipped with irrigation infrastructure, which is not necessarily used, depending on the climatic conditions in a specific year

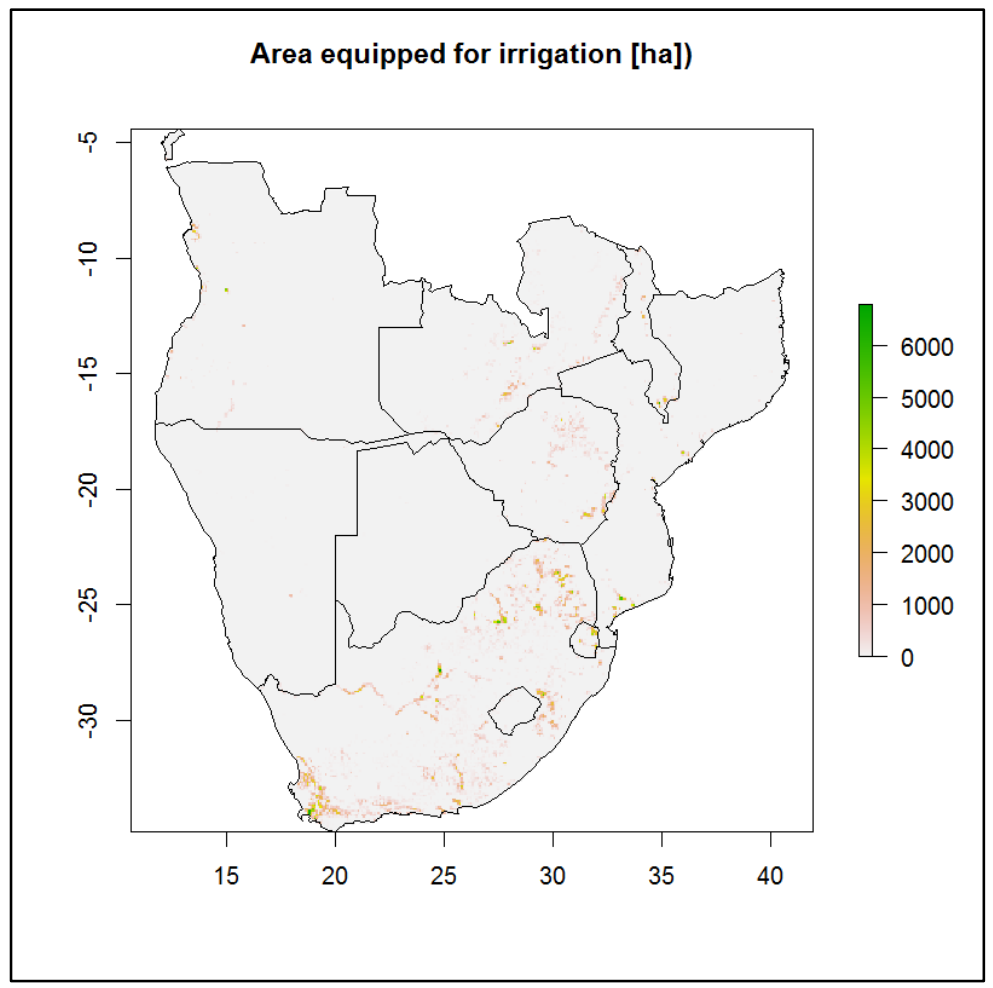

Source: FAO AQUASTAT (available at: www.fao.org/nr/aquastat/).

\subsection{Developing a mask of unsuitable soils}

A simplified mask was created to give a regional overview as to where biofuel production is likely to be a land use option based on biophysical constraints.

Certain areas are clearly no-go areas for biofuel, including all areas classified as some form of conservation or wildlife management area. It might be that in some of the community areas or biosphere areas some level of cropping would be permissible, but for simplicity we have assumed that all these areas would not be available. The conservation mask is thus as per Figure 18a.

We also excluded areas with a high percentage of forest, using a cut-off of 60 per cent forest per grid cell as the criterion (Figure 18b). 
Figure 18: a) Conservation mask; b) Areas with over $60 \%$ forest
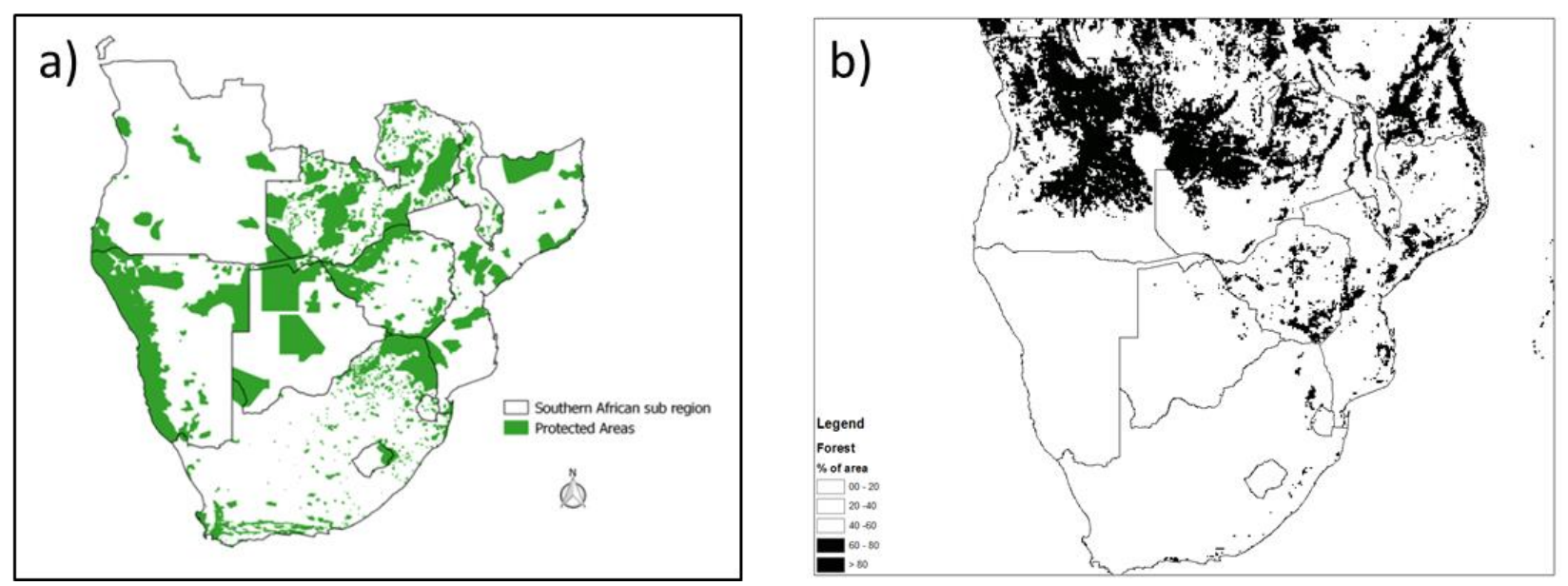

Source: WDPA (World Database of Protected Areas): https://www.protectedplanet.net/.

In addition, areas of high human density such as cities should be excluded, but these represent small areas hardly discernible on landcover maps. It is also debatable whether all existing agricultural areas should be excluded. From a food security perspective it could be argued that this should be the case-and may be justified for South Africa. However, for a crop such as the existing sugarcane, diverting some of it to biofuel may well be justified. Further, as will be argued elsewhere, converting some existing African agriculture to biofuel need not impact on food production as there is a good potential to make up the shortfall simply through the use of better agronomic practices. From the perspective of a local farmer, cash income may offset loss of food crop production-especially since the household may continue to practise both food and fuel production (von Maltitz et al. 2014, 2016). We have not placed any existing agriculture constraints on the mask.

From a soil constraints perspective we have excluded all areas that have severe or worse rooting conditions, oxygen availability, excess salts, toxicity, or workability or have very severe nutrient availability or nutrient retention capacity. For soil constraints pertaining to nutrients, we have excluded only soils with 'very severe' constraints, as nutrient constraints can be largely overcome through fertilizer use. Figure 19a shows the soil mask and Figure 19b the slope constraint mask (see Figure 9). 
Figure 19: Masks for a) soil constraints and b) slope constraints

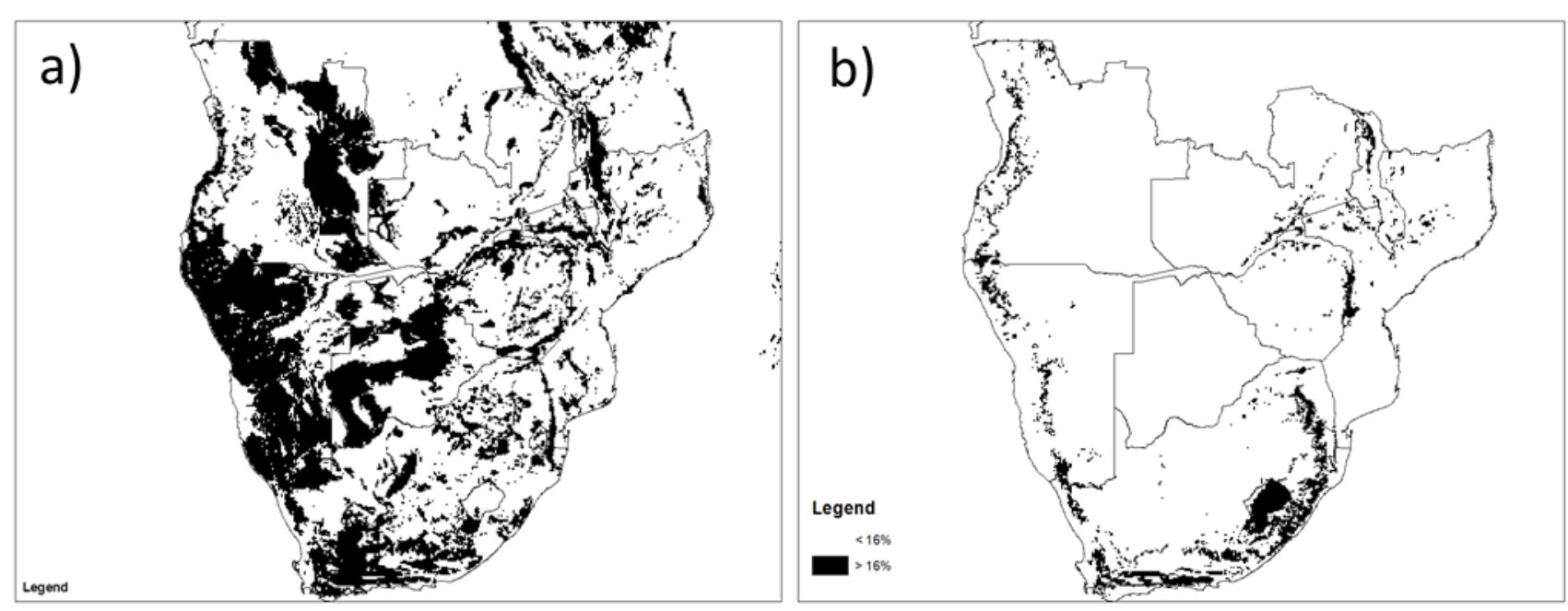

Source: Derived form Fischer et al. (2008).

For dryland cropping we assume that $500 \mathrm{~mm}$ of rain is the minimum annual precipitation for biofuel production. This is above the absolute minimum rainfall requirements for the potential biofuel crops considered. We realize that some oilseed crops may be feasible below this level (sunflower, for example, requires a minimum of $250 \mathrm{~mm}$ per year under rainfed conditions), but in more arid areas yields are low and the risk of drought is high, so that $500 \mathrm{~mm}$ is probably a reasonable minimum for practical purposes.

When all these constraints are included and masked out, the areas left as potentially suitable for dryland biofuel production are as shown in Figure 20. Mean annual rainfall is given for potential areas as a broad guideline of crop suitability. 
Figure 20: Mask of areas potentially suitable for biofuel crop production overlaid on mean annual precipitation

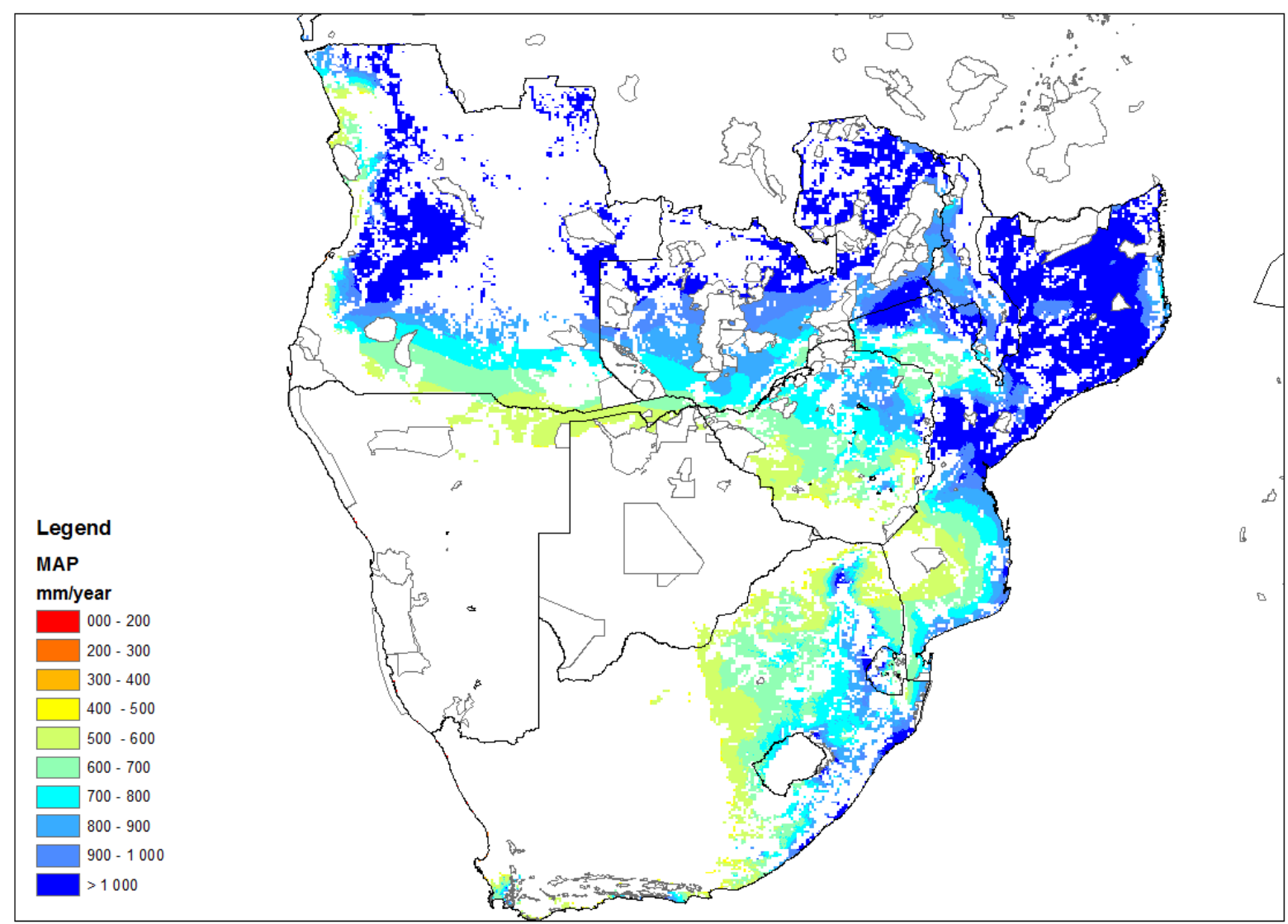

Note: All areas excluded (i.e. white in the diagram) have one or more limiting factors, making them potentially unsuitable. Local verification of suitability would still be required for areas highlighted as potentially suitable.

Source: Derived for data from Fischer et al. (2008), WDPA (World Database of Protected Areas):

https://www.protectedplanet.net/.; FAO (2001); and WorldClim 1.4 data (data available at: http://worldclim.org ).

\section{Crop suitability}

\subsection{Screening for potentially suitable crops}

A literature scan was undertaken to find which crops are currently being promoted as biofuel crops, particularly within the tropics. The following list of crops was identified for further consideration:

- First-generation crops: Oils

- Sunflower seed (Helianthus annuиs L.; seeds)

- Soybeans (Glycine maximum Merr.; seeds)

- Jatropha (Jatropha curcas L.; seeds)

- Tobacco (Nicotiana tabacum L. Solaris biotype; oil from seeds)

- Second-generation crops: Biomass to oil technologies

- Plantains (Musa paradisiaca L.; peels)

- Switchgrass (Panicum virgatum L.; stems)

- Tobacco (Nicotiana tabacum L. Solaris biotype; leaves and stalks)

- Sorghum (Sorghum bicolor (L.) Moench; all biomass)

- Tree species (Eucalyptus spp; all biomass)

- First-generation crops: Sugars 
- Sweet sorghum (Sorghum bicolor (L.) Moench varieties cultivars; stems)

- Sugar cane (Saccharum officinarum L; stems)

- Sugar beet (Beta vulgaris (L.) var. saccharifera; roots)

- Tropical sugar beet (Beta vulgaris L. Syngenta ${ }^{\circledR}$ and altissima Doll varieties; roots)

- First-generation crops: Starches

- Cassava (Manihot esculenta Crantz; roots)

- Maize (Zea mays L.; seeds)

- Grain sorghum (Sorghum bicolor (L.) Moench; seeds)

- Second-generation crops: Cellulosic feedstocks

- Switchgrass (Panicum virgatum; stems)

- Tobacco (Nicotiana tabacum L. Solaris biotype; leaves and stems)

- Sorghum (Sorghum bicolor (L.) Moench; stems, leaves, and seeds)

- Maize (Zea mays L.; stems and leaves)

- Sugarcane (Saccharum officinarum L.; stems and leaves).

\subsection{Overview of potential crops}

Maize (Zea mays, L.)

Maize is currently the main biofuel crop for ethanol grown in the United States. It is unlikely to be considered a biofuel crop in the Southern Africa region, however, because of concerns over foodfuel conflicts, as maize is the staple food crop over much of the sub-region. South Africa has specifically excluded maize from its biofuel strategy on the basis of this concern. It is, however, still useful to consider maize, as it is a well-studied crop, and it gives a good baseline against which other crops can be compared. Maize is an annual, $\mathrm{C}_{4}$ grass (Duke 1983; FAO 2006) and the seeds can be used as a starch source for ethanol (alcohol) through a simple distillation process (FAO 2006). Broad growth parameters for maize are given in Table 2.

Currently, maize ethanol is produced from the maize seed. It is likely that second-generation ethanol will be produced from maize stalks in the future. The stalk-to-seed ratio on a dry mass basis is very close to $1: 1$ and this ratio stays relatively constant with yield. Nevertheless, the use of maize stalks in Southern Africa for ethanol does not appear to be a likely scenario for two reasons. First, current maize yields are very low, meaning that the mass of stalks is also low. This means that stalks would have to be collected from vast areas to make up the volumes required of a secondgeneration biofuel crop. If in the future there are large areas of high-yielding maize, this option might become a possibility. Second, much of the current yield of maize stalks is either used for cattle silage or ploughed back into the soil to enhance soil structure and carbon. 
Table 2: Maize crop requirements

\begin{tabular}{|c|c|c|c|c|c|c|c|}
\hline Climate factors & Optir & & Abso & & Soil attributes & Optimal & Absolute \\
\hline & Min. & Max. & Min. & Max. & Soil depth & $\begin{array}{l}\text { Medium } \\
(50-150 \mathrm{~cm})\end{array}$ & $\begin{array}{l}\text { Shallow } \\
(20-50 \mathrm{~cm})\end{array}$ \\
\hline $\begin{array}{l}\text { Daily } \\
\text { temperature } \\
\text { requirement }\left({ }^{\circ} \mathrm{C}\right)\end{array}$ & 18 & 33 & 10 & 47 & $\begin{array}{l}\text { Soil texture } \\
\text { Soil fertility }\end{array}$ & High & Low \\
\hline $\begin{array}{l}\text { Rainfall (annual) } \\
\text { (mm) }\end{array}$ & 600 & 1,200 & 400 & 1,800 & Soil al. tox. & & \\
\hline $\begin{array}{l}\text { Latitude } \\
\text { (degrees) }\end{array}$ & & & 40 & 48 & & Low $(<4 \mathrm{dS} / \mathrm{m})$ & $\begin{array}{l}\text { Medium } \\
(4-10 \mathrm{dS} / \mathrm{m})\end{array}$ \\
\hline $\begin{array}{l}\text { Altitude } \\
\text { (mmasl) }\end{array}$ & & & & 4,000 & Soil drainage & & \\
\hline Soil pH & 5 & 7 & 4.5 & 8.5 & & & \\
\hline
\end{tabular}

Köppen Climate Zones: tropical wet (Ar), tropical wet and dry (Aw), steppe or semiarid (Bs), subtropical humid (Cf), subtropical dry summer (Cs), subtropical dry winter (Cw), temperate continental (Dc), temperate with humid winters (Df), temperate oceanic (Do), temperate with dry winters (Dw) (FAO 2006).

Source: FAO EcoCrop database (available at: www.ecocrop.fao.org).

Sorghum (Sorghum bicolor (L.) Moench)

Sorghum, a $\mathrm{C}_{4}$ grass indigenous to Africa, is a traditional crop that was extensively grown in the sub-region in the past but is less common nowadays. It has a reputation for being more droughthardy than maize, and can be grown in slightly more arid areas. It is also quoted as requiring less nitrogen fertilizer (Smith 2000). It has exceptionally high water-use and light-use efficiencies, making it one of the most efficient crops for converting light and water into biomass (Gosse 1996; Curt et al. 1998). The grain from sorghum can be used for ethanol in the same way as maize grain. The area planted with sorghum in South Africa is on average about 67,600 $\pm 17,100$ ha for 2005/06-2015/16 (DAFF, 2016). Yields of about $3.0 \pm 0.5$ tons/ha were obtained for the same period, compared with the maximum potential yield of 14.2 tons/ha estimated by the GAEZ model. Most of the sorghum ( $>80$ per cent) is produced in the Free State and Mpumulanga provinces of South Africa (DAFF 2016).

Sorghum is adapted to a wide range of habitats ranging from $45^{\circ} \mathrm{N}$ to $45^{\circ} \mathrm{S}$ and can be grown at a wide range of altitudes, though is more commonly found above $900 \mathrm{~m}$ in Africa. As a $\mathrm{C}_{4}$ crop, sorghum flourishes under hot tropical conditions with optimal temperature for photosynthesis in the $32-34{ }^{\circ} \mathrm{C}$ range and a day length of 10 to 14 hours (Srinivasa Rao et al. 2014). It is, however, relatively cold sensitive, showing chilling injuries at temperatures below $15^{\circ} \mathrm{C}$ (Peacock 1982). Sorghum can be grown over a wide range of soils from sands to relatively heavy clays (verticals) and over a wide pH range from 5.4. to 8.5 (Du Plessis 2008, Butchee et al. 2012). This tolerance to acidic soils means that it can be grown in many of the highly-leached soils of the phosphorusdeficient and aluminium toxic soil of the miombos. Although susceptible to flooding, sorghum has higher tolerance to temporary waterlogging than corn (Khawaja 2014), making it a crop that can be grown in the seasonally waterlogged dambos of the miombo regions.

Many claims are made that sorghum is a dual crop, giving both grain and stalks. It is currently unknown if this is a realistic expectation, as management practices may differ between the two products and it may prove difficult to optimize for both. Bitzer (2009), for instance, says that to maximize sugar yields, seed heads should be removed in the late 'milk stage' to prevent stalk sugars being depleted during the production of seeds. 
Considerable interest in the biofuel literature is on a sorghum variety called sweet sorghum. Sweet sorghum has a stem that accumulates sugar in a very similar way to sugarcane, with a brix of about 16 and yields of 54-69 t/ha (Khawaja et al. 2014). Sweet sorghum is well known as a drought tolerant crop due to its ability to go into a state of dormancy when water stressed (Gnansounou et al. 2005) and has an optimum rainfall range of 550-800 $\mathrm{mm}$, making it well suited to the drier regions of Southern Africa (Du Plessis 2008).

It is also suggested that, because the cropping cycle is only about four months, multiple crops (two or even three) could be grown per year in tropical areas. In Southern Africa, however, the arid winters would make this impossible unless supplementary irrigation were available.

Though sweet sorghum may have good yields, there may be logistical constraints to its use as a biofuel. Since it is an annual crop, its cropping cycle would be linked to rainfall, and it is likely that all the yield in a region would be available only in a concentrated one-month period. Like sugarcane, the crop value decreases rapidly after harvesting, and sweet sorghum ideally needs to be processed within one day of harvesting. After three days, 16 per cent of the sugar yield is lost (Reddy et al. 2008).

Many claims for sweet sorghum as a feedstock have been made, but because the crop is relatively new, it is hard to verify many of these. Yield data, other than from experimental trials, are very scarce and achievable yields, in production systems, are largely unknown for the region. This is, however, a crop that should be closely watched, as it may well be an important biofuel crop in the future.

A comparison between sugarcane and sweet sorghum yields and growth requirements is given in Table 3.

Table 3: Comparison of sugarcane and sweet sorghum

\begin{tabular}{|c|c|c|}
\hline & Sugarcane & Sweet sorghum \\
\hline Crop duration & About 7 months & About 4 months \\
\hline Growing season & Only one season & $\begin{array}{l}\text { One season in temperate areas and 2-3 } \\
\text { seasons in tropical areas }\end{array}$ \\
\hline Soil requirement & Grows well in drained soil & $\begin{array}{l}\text { All types of drained soil except very sandy } \\
\text { soils }\end{array}$ \\
\hline Water management & $36,000 \mathrm{~m}^{3} / \mathrm{ha}$ & $12,000 \mathrm{~m}^{3} / \mathrm{ha}$ \\
\hline Crop management & Requires good management & $\begin{array}{l}\text { Little fertilizer required; less susceptible to } \\
\text { pests and diseases; easy management }\end{array}$ \\
\hline Yield & $70-80 \mathrm{t} / \mathrm{ha}$ & $54-69 \mathrm{t} / \mathrm{ha}$ \\
\hline $\begin{array}{l}\text { Sugar content on weight } \\
\text { basis }\end{array}$ & $10-12 \%$ & $7-12 \%$ \\
\hline Sugar yield & $7-8 \mathrm{t} / \mathrm{ha}$ & $6-8 \mathrm{t} / \mathrm{ha}$ \\
\hline $\begin{array}{l}\text { Ethanol production directly } \\
\text { from juice }\end{array}$ & $3,000-5,000 \mathrm{l} / \mathrm{ha}$ & $3,000 \mathrm{l} / \mathrm{ha}$ \\
\hline Harvesting & Mechanical harvest & Very simple; both manual and mechanical \\
\hline
\end{tabular}

Source: Almodares and Hatamipour (2011).

Biomass sorghum is a variety of sorghum that accumulates biomass as complex polysaccharides and accumulates fewer simple sugars than sweet sorghum. This may be an appropriate crop for second-generation biofuels, where bulk biomass rather than sugars are required. 


\section{Cassava (Manihot esculenta Crantz)}

Cassava is a shrubby perennial tropical plant with a fibrous root system (FAO 2006). The roots, as a starch, can be used for ethanol production using standard fermentation processes (FAO 2006). Cassava is a traditional crop grown over much of tropical Africa, especially in the lowlands. It is most common in areas with low suitability for maize, where it becomes the main staple crop.

Cassava has a higher energy density than sugarcane and, if not damaged, it can store reasonably well for short periods. It also stores well underground over a potentially long harvest period.

Yields of cassava in Africa are some of the lowest in the world, at around $10.8 \mathrm{t} / \mathrm{ha}$ (FAO 2013). Yield data for commercial growth of cassava under good management conditions are largely lacking from Africa, as the crop tends to be mostly grown for subsistence purposes. Data from elsewhere in the world suggest that large yield improvements may well be possible. Fermont et al. (2009) showed that yields of 30-40 t/ha are attainable in Africa. It has also been suggested that through breeding it might be possible to further enhance yields.

The production figures for the actual, potential, and agro-climatically attainable yields (Figure 21) are for the harvested roots. Broad growth parameters for cassava are given in Table 4.

Table 4: Cassava crop requirements

\begin{tabular}{|c|c|c|c|c|c|c|c|}
\hline \multirow[t]{2}{*}{ Climate factors } & \multicolumn{2}{|c|}{ Optimal } & \multicolumn{2}{|c|}{ Absolute } & \multirow{2}{*}{$\begin{array}{l}\text { Soil } \\
\text { attributes } \\
\text { Soil depth }\end{array}$} & \multirow{2}{*}{$\begin{array}{l}\text { Optimal } \\
\text { Medium } \\
(50-150 \\
\mathrm{cm})\end{array}$} & \multirow{2}{*}{$\begin{array}{l}\text { Absolute } \\
\text { Medium } \\
(50-150 \mathrm{~cm})\end{array}$} \\
\hline & Min. & Max. & Min. & Max. & & & \\
\hline $\begin{array}{l}\text { Daily } \\
\text { temperature } \\
\text { requirement }\left({ }^{\circ} \mathrm{C}\right)\end{array}$ & 20 & 29 & 10 & 35 & Soil texture & $\begin{array}{l}\text { Medium, } \\
\text { light }\end{array}$ & $\begin{array}{l}\text { Heavy, medium, } \\
\text { light, organic }\end{array}$ \\
\hline $\begin{array}{l}\text { Rainfall (annual) } \\
\text { (mm) }\end{array}$ & 1,000 & 1,500 & 500 & 5,000 & Soil fertility & Moderate & Low \\
\hline $\begin{array}{l}\text { Latitude } \\
\text { (degrees) }\end{array}$ & & & 25 & 30 & Soil al. tox. & & \\
\hline Altitude (mmasl) & & & & 2,000 & Soil salinity & $\begin{array}{l}\text { Low } \\
(<4 \mathrm{dS} / \mathrm{m})\end{array}$ & Low $(<4 \mathrm{dS} / \mathrm{m})$ \\
\hline Soil ph & 5.5 & 8 & 4 & 9 & $\begin{array}{l}\text { Soil } \\
\text { drainage }\end{array}$ & $\begin{array}{l}\text { Good (dry } \\
\text { spells) }\end{array}$ & $\begin{array}{l}\text { Good (dry spells), } \\
\text { excessive } \\
\text { (dry/moderately } \\
\text { dry) }\end{array}$ \\
\hline Climate zone & $\mathrm{r}, \mathrm{Aw}$ & & & & & & \\
\hline
\end{tabular}

Köppen Climate Zone requirements: tropical wet (Ar), tropical wet and dry (Aw), steppe or semiarid (Bs) (FAO 2006).

Source: FAO EcoCrop database (available at: www.ecocrop.fao.org).

Tropical sugar beet (Beta vulgaris var. L. var. saccharifera)

Sugar beet, and specifically the saccharifera variety, is a herbaceous plant that stores reserves in the root during the first growing season. It flowers and produces seeds only in the following summer (FAO 2006). The root contains sugar that can be used for alcohol and ethanol production. Sugar beet has traditionally been a temperate climate crop. New varieties are, however, being bred that do well in tropical environments and are resistant to both high temperatures and drought (during later stages of growth). Claims have been made that beet can outperform sugarcane in some environments and with less use of water. Beet is also able to stay in the ground for relatively long 
periods after maturity, but prior to harvesting. It needs to be processed within one or two days of harvesting, though.

Data on tropical sugar beet as a biofuel crop for Southern Africa are still relatively scarce, but this may prove to be a very viable crop in the future once it has been tested for specific sites. Elbersen and Oyen (2010) suggest that fresh yields of 60-80 t/ ha are possible, with a sugar yield of 9.5-14 $\mathrm{t} / \mathrm{ha}$. This corresponds well with yields from trials in Bangladesh (Islam et al. 2012). This would put beet on a par with sugarcane yields from Brazil, but with lower water requirements.

The crop can be grown over a wide range of temperatures. Early growing season irrigation may be required if rainfall cannot be relied upon, as the crop is sensitive to drought in its early stages. It is relatively drought-tolerant once mature (Tamil Nadu n.d.). The crop is susceptible to waterlogging, and is best grown on relatively sandy soils.

Sugarcane (Saccharum officinarum L.)

Sugarcane is a $\mathrm{C}_{4}$ perennial grass and the stems are used to produce sugar, which can be easily converted into ethanol through fermentation (FAO 2006). Sugarcane, grown for sugar, is a wellestablished commercial crop grown in most Southern African countries. Only Malawi currently uses sugarcane for fuel ethanol, though both South Africa and Zimbabwe have done this in the past. Sugarcane is the basis for the Brazilian ethanol industry and is a well understood crop. Southern African yields, especially under irrigation, tend to exceed the international mean, and yields of over $100 \mathrm{t} / \mathrm{ha}$ are common.

Sugarcane is harvested on annual or 18-month cycles and regrows from ratoons, only needing to be replanted every 8 to 10 cycles. Given the existing sugarcane plantations and the vast experience around sugarcane production, it is an obvious choice for biofuel expansion.

From an agronomy perspective, the biggest probable constraints to sugarcane growing are its high water demand and the fact that in most areas this can be met only through irrigation due to the prolonged dry seasons experienced in most of the sub-region.

Sugarcane has one of the highest per hectare ethanol yields, though it might be possible that sweet sorghum or tropical sugar beet would match these yields under some circumstances. However, both these alternative crops are poorly researched in the region and would require extensive trials before being promoted for large-scale biofuel expansion. Broad growth parameters for sugarcane are given in Table 5 . 
Table 5: Sugarcane crop requirements

\begin{tabular}{|c|c|c|c|c|c|c|c|}
\hline \multirow[t]{2}{*}{ Climate factors } & \multicolumn{2}{|c|}{ Optimal } & \multicolumn{2}{|c|}{ Absolute } & \multirow{2}{*}{$\begin{array}{l}\begin{array}{l}\text { Soil } \\
\text { attributes }\end{array} \\
\text { Soil depth }\end{array}$} & \multirow{2}{*}{$\begin{array}{l}\text { Optimal } \\
\text { Deep }(>150 \mathrm{~cm})\end{array}$} & \multirow{2}{*}{$\begin{array}{l}\text { Absolute } \\
\text { Medium } \\
(50-150 \mathrm{~cm})\end{array}$} \\
\hline & Min. & Max. & Min. & Max. & & & \\
\hline $\begin{array}{l}\text { Daily } \\
\text { temperature } \\
\text { requirement }\left({ }^{\circ} \mathrm{C}\right)\end{array}$ & 24 & 37 & 15 & 41 & Soil texture & $\begin{array}{l}\text { Well structured } \\
\text { and aerated } \\
\text { loams and sandy } \\
\text { loam }>1 \text { m deep } \\
\text { with plant } \\
\text { available water } \\
\text { greater than } 150 \\
\text { mm (Jewitt et al. } \\
\text { 2009) }\end{array}$ & $\begin{array}{l}\text { Well under a } \\
\text { range of soils }\end{array}$ \\
\hline $\begin{array}{l}\text { Rainfall (annual) } \\
\text { (mm) }\end{array}$ & 1,500 & 2,000 & 1,000 & 5,000 & Soil fertility & High & Moderate \\
\hline $\begin{array}{l}\text { Latitude } \\
\text { (degrees) }\end{array}$ & & $30 \mathrm{~N}$ & $33 \mathrm{~S}$ & $33 \mathrm{~N}$ & Soil al. tox. & & \\
\hline Altitude (mmasl) & & & 0 & 1600 & Soil salinity & $\operatorname{Low}(<4 \mathrm{dS} / \mathrm{m})$ & $\begin{array}{l}\text { Medium } \\
(4-10 \mathrm{dS} / \mathrm{m})\end{array}$ \\
\hline Soil pH & 5 & 8 & 4.5 & 9 & $\begin{array}{l}\text { Soil } \\
\text { drainage }\end{array}$ & Well drained & $\begin{array}{l}\text { Can tolerate } \\
\text { poorly drained } \\
\text { soils for short } \\
\text { periods }\end{array}$ \\
\hline
\end{tabular}

Köppen Climate Zone requirements: tropical wet (Ar), tropical wet and dry (Aw), subtropical humid (Cf) (FAO 2006).

Source: FAO EcoCrop database (available at: www.ecocrop.fao.org).

Soybean (Glycine maximum Merr.)

Soybean grows as a bushy herbaceous legume. The bean pods and seeds are a source of oil and protein and the oil can be converted into biofuel through transestification (FAO 2006).

Jewitt et al. (2009) reported an average annual harvested area of about 120,000 ha in South Africa based on national values for the period 1997/98-2004/05. Soybean is mainly produced in the Mpumalanga and KwaZulu-Natal provinces, i.e. 48 per cent and 22 per cent, respectively, of the total area cultivated with soybean in the country. Average soybean yields for South Africa are between 1.6 and $1.7 \mathrm{t} / \mathrm{ha}$ (Schulze and Maharaj 2007). The maximum attainable yield in the subregion is about $7.2 \mathrm{t} / \mathrm{ha}$. Soybean is the most rapidly expanding crop in South Africa at present. Large soy projects have also been initiated in Mozambique and Zambia. Currently, however, the yield is used for human or animal consumption, not biofuel.

A huge potential advantage of soybean is that, after the oil has been extracted, the remaining seedcake is a protein-rich animal food and can be used as a poultry or livestock food supplement. This dual market for the seed makes it more financially viable as a biodiesel feedstock than would be the case if it were grown only as a fuel.

The high demand for oil for human consumption in Southern Africa makes it unlikely that soybean would be grown as a biofuel crop, given that it will have a far higher value as a food crop. Only once the food demand is exceeded will it have potential as a fuel crop.

Soybean cultivation has been linked with deforestation in the Amazon, and large areas of land transformation, including deforestation, would be a concern if large-scale production were to be envisaged in Southern Africa. Large-scale soybean production can be easily mechanized, reducing the crop's developmental benefits. Broad growth parameters for soybean are given in Table 6. 
Table 6: Soybean crop requirements

\begin{tabular}{|c|c|c|c|c|c|c|c|}
\hline \multirow[t]{2}{*}{ Climate factors } & \multicolumn{2}{|c|}{ Optimal } & \multicolumn{2}{|c|}{ Absolute } & \multirow{2}{*}{$\begin{array}{l}\text { Soil } \\
\text { attributes } \\
\text { Soil depth }\end{array}$} & \multirow{2}{*}{$\begin{array}{l}\text { Optimal } \\
\text { Medium } \\
(50-150 \\
\mathrm{cm})\end{array}$} & \multirow{2}{*}{$\begin{array}{l}\text { Absolute } \\
\text { Shallow } \\
(20-50 \mathrm{~cm})\end{array}$} \\
\hline & Min. & Max. & Min. & Max. & & & \\
\hline $\begin{array}{l}\text { Daily } \\
\text { temperature } \\
\text { requirement }\left({ }^{\circ} \mathrm{C}\right)\end{array}$ & 20 & 33 & 10 & 38 & Soil texture & $\begin{array}{l}\text { Medium, } \\
\text { organic }\end{array}$ & $\begin{array}{l}\text { Heavy, medium, } \\
\text { light }\end{array}$ \\
\hline $\begin{array}{l}\text { Rainfall (annual) } \\
\text { (mm) }\end{array}$ & 600 & 1,500 & 450 & 1,800 & Soil fertility & High & Low \\
\hline $\begin{array}{l}\text { Latitude } \\
\text { (degrees) }\end{array}$ & & & 47 & 52 & Soil al. tox. & & \\
\hline Altitude (mmasl) & & & & 3,000 & Soil salinity & $\begin{array}{l}\text { Low }(<4 \\
\mathrm{dS} / \mathrm{m})\end{array}$ & $\begin{array}{l}\text { Medium } \\
(4-10 \mathrm{dS} / \mathrm{m})\end{array}$ \\
\hline Soil pH & 5.5 & 6.5 & 4.5 & 8.4 & $\begin{array}{l}\text { Soil } \\
\text { drainage }\end{array}$ & $\begin{array}{l}\text { Good (dry } \\
\text { spells) }\end{array}$ & $\begin{array}{l}\text { Poor (saturated } \\
>50 \% \text { of year), } \\
\text { good (dry spells), } \\
\text { excessive } \\
\text { (dry/moderately } \\
\text { dry) }\end{array}$ \\
\hline
\end{tabular}

Climate zone Aw, Bs, Cs

Köppen Climate Zone requirements: tropical wet and dry (Aw), steppe or semiarid (Bs), subtropical dry summer (Cs) (FAO 2006).

Source: FAO EcoCrop database (available at: www.ecocrop.fao.org).

Sunflower (Helianthus annuus L.)

Sunflower is a fast-growing annual $\mathrm{C}_{3}$ herb and the seeds are used for the production of biodiesel (FAO 2006). Like soybean seeds, sunflower seeds can be used as a food crop or for food oil. Relatively low per hectare yields mean that it is not the most efficient crop for fuel production. Broad growth parameters for sunflower are given in Table 7. 
Table 7: Sunflower crop requirements

\begin{tabular}{|c|c|c|c|c|c|c|c|}
\hline \multirow[t]{2}{*}{ Climate factors } & \multicolumn{2}{|c|}{ Optimal } & \multicolumn{2}{|c|}{ Absolute } & \multirow{2}{*}{$\begin{array}{l}\text { Soil attributes } \\
\text { Soil depth }\end{array}$} & \multirow{2}{*}{$\begin{array}{l}\text { Optimal } \\
\text { Medium } \\
(50-150 \mathrm{~cm})\end{array}$} & \multirow{2}{*}{$\begin{array}{l}\text { Absolute } \\
\text { Medium } \\
(50-150 \\
\mathrm{cm})\end{array}$} \\
\hline & Min. & Max. & Min. & Max. & & & \\
\hline $\begin{array}{l}\text { Daily temperature } \\
\text { requirement }\left({ }^{\circ} \mathrm{C}\right)\end{array}$ & 17 & 34 & 5 & 45 & Soil texture & $\begin{array}{l}\text { Medium, } \\
\text { light }\end{array}$ & $\begin{array}{l}\text { Heavy, } \\
\text { medium, } \\
\text { light }\end{array}$ \\
\hline $\begin{array}{l}\text { Rainfall (annual) } \\
\text { (mm) }\end{array}$ & 600 & 1,000 & 300 & 1,600 & Soil fertility & High & Low \\
\hline Latitude (degrees) & 20 & & 50 & 55 & Soil al. tox & & \\
\hline Altitude (mmasl) & & & & 2,600 & Soil salinity & $\begin{array}{l}\text { Low }(<4 \\
\mathrm{dS} / \mathrm{m})\end{array}$ & $\begin{array}{l}\text { Low }(<4 \\
\mathrm{dS} / \mathrm{m})\end{array}$ \\
\hline Soil pH & 6 & 7.5 & 5.5 & 8 & Soil drainage & $\begin{array}{l}\text { Good (dry } \\
\text { spells) }\end{array}$ & $\begin{array}{l}\text { Good (dry } \\
\text { spells) }\end{array}$ \\
\hline
\end{tabular}

Note: Köppen Climate Zone requirements: tropical wet and dry (Aw), steppe or semiarid (Bs), subtropical humid (Cf), subtropical dry summer (Cs), subtropical dry winter (Cw), temperate continental (Dc), temperate with humid winters (Df), temperate oceanic (Do), temperate with dry winters (Dw) (FAO 2006).

Source: FAO EcoCrop database (available at: www.ecocrop.fao.org).

Jatropha (Jatropha curcas L.)

Jatropha has been the preferred biofuel crop in the sub-region and has been grown extensively. Yields have fallen far short of expectations, however, and almost all jatropha projects have collapsed (von Maltitz et al. 2014, 2016).

Unless new, high-yielding varieties of jatropha are developed and locally tested, it should not be considered as a biofuel option for any new projects. It remains to be seen if the last few existing projects will survive.

A key further constraint to jatropha is that the seeds are toxic. This prevents the high-protein seedcake from being used as animal fodder. Chemical and heat treatments have been proposed to overcome this constraint, but these would add a further cost to the process. Non-toxic varieties have also been identified, but unless these can be developed to give high yields, they will have the same constraints as other jatropha varieties.

The high labour requirement of jatropha is potentially a mixed attribute. It would bring large numbers of jobs (as opposed to crops such as soybean, which are mechanically harvested), but would also push up costs. However, this is a moot point unless high-yielding varieties are developed.

Tobacco (Nicotiana tabacum L.)

A specially bred seed tobacco called Solaris is being piloted in South Africa by the aviation industry as a biofuel crop for aviation use. Trials using this fuel for aviation purposes have proved successful and wide-scale expansion of the project is being proposed to meet South African Airways' and Boeing's biofuel blending targets.

In essence, Solaris is similar to other oilseeds in the sense that seeds are harvested and crushed for oil, with the option of a high-value protein-rich seedcake. This crop was developed in Italy, and has had only about three years of trials in South Africa. Initial results suggest a promising oil yield 
per hectare when grown under irrigation. More recent trials are assessing dryland yields. Reports of $2.5 \mathrm{t} /$ ha have appeared in the media, but operational yields in real-world situations still need to be confirmed. If these yields, which are better than most competing oilseed crops, can be sustained, this would give Solaris an advantage.

It may also be possible to use tobacco leaves for second-generation biofuels, as they have a relatively high per hectare yield. Although tobacco is not seen as a leading contender among second-generation biofuel crops, it should not be fully disregarded as a potential option.

Switchgrass (Panicum virgatum L.) and miscanthus (Miscanthus giganteus)

Switchgrass and miscanthus are two high-yielding grass species proposed in the USA for secondgeneration biofuel crop production. Neither species is well suited to the Southern African environment (other than in some areas of South Africa, as demonstrated for switchgrass in Figure 24) and, after initial screening, they have not been included in the list of potential crops. Biomass sorghum is a more likely second-generation alternative.

A further concern with these two crops is their invasive potential. Many of the features that make crops suitable for biofuel, such as rapid growth, are also features that may be indicative of invasiveness (IUCN 2009).

\section{Short-rotation forestry}

For a second- or third-generation biofuel, it is the biomass production that is the main consideration. In this regard, woody species may be an appropriate option. Theoretically, a $\mathrm{C}_{4}$ grass should out-perform a $\mathrm{C}_{3}$ tree, especially in hot climates. However, the perennial nature of trees may make them a preferred and cost-effective option.

For the region it is eucalyptus plantations that show the best potential. These have been well developed in the pulp and paper industry. In South Africa, eucalyptus is grown on an eight-year rotation. Conditions in Mozambique and Zambia should give even higher yields than are being achieved in South Africa.

Summary of crop data

Table 8 provides an overview of the likely biofuel yield per tonne of feedstock as well as yield data per country, highlighting the country with the highest potential per feedstock. It is important to take into consideration that yields may be far higher than the table suggests if crops are grown under optimal management conditions (see Figure 24). Experience from the sugarcane industry suggests that when there is good support for an industrial crop it is quite possible for best-in-world yields to be achieved, despite the fact that far lower yields are currently being achieved in the target countries.

Sugarcane is the only current potential crop which is being reliably grown for high yields throughout the region. It is a proven crop for which the agronomy and conversion to ethanol is well understood. Alternative crops such as sweet sorghum and tropical sugar beet could in many aspects outperform sugarcane, but they are currently untested over the region and their long-term responses to growth under changing climate conditions are not known. Nevertheless, these are crops that may have good potential in the future. 
Table 8: Potential biofuel yields for different types of crop feedstock within the sub-region

\begin{tabular}{|c|c|c|c|c|c|c|c|c|c|c|c|c|c|}
\hline \multirow{2}{*}{$\begin{array}{l}\text { Biofuel crop } \\
\text { (part used for } \\
\text { biofuel) }\end{array}$} & \multirow{2}{*}{$\begin{array}{l}\text { Conversion } \\
\text { efficiency: } \\
\text { yield } \\
\text { ethanol } \\
\text { (litres/tonne } \\
\text { harvested } \\
\text { biomass) }\end{array}$} & \multirow{2}{*}{$\begin{array}{l}\text { Conversion } \\
\text { efficiency: } \\
\text { yield } \\
\text { biodiesel } \\
\text { (litres/tonne } \\
\text { harvested } \\
\text { biomass) }\end{array}$} & \multirow{2}{*}{$\begin{array}{l}\text { Note } \\
\text { s }\end{array}$} & \multicolumn{10}{|c|}{ Potential rainfed crop yields: area-weighted harvested yield (tonne/ha) } \\
\hline & & & & Angola & Botswana & Lesotho & Malawi & Mozambique & Namibia & $\begin{array}{l}\text { South } \\
\text { Africa }\end{array}$ & Swaziland & Zambia & Zimbabwe \\
\hline $\begin{array}{l}\text { Cassava } \\
\text { (roots/starch) }\end{array}$ & 180 & & & 14.5 & 3.8 & NS & 12.6 & 16.3 & 3.7 & 8.7 & 8.0 & 14.0 & 6.4 \\
\hline $\begin{array}{l}\text { Maize } \\
\text { (seeds/starch) }\end{array}$ & 400 & & & 5.9 & 4.2 & 3.2 & 6.2 & 8.7 & 2.7 & 5.0 & 4.3 & 8.7 & 5.7 \\
\hline $\begin{array}{l}\text { Sorghum } \\
\text { (grains) }\end{array}$ & 380 & & & 4.6 & 4.3 & 2.9 & 5.2 & 6.7 & 2.7 & 4.0 & 3.8 & 6.9 & 4.6 \\
\hline $\begin{array}{l}\text { Sweet sorghum } \\
\text { (stalks) }\end{array}$ & $43-55$ & & 1. & \multicolumn{10}{|c|}{$\begin{array}{l}\text { No data; trials in Zambia are looking positive. Though unlikely to outperform sugarcane (unless under irrigation) } \\
\text { may produce high dryland yields in areas too dry for sugarcane. }\end{array}$} \\
\hline $\begin{array}{l}\text { Sugar cane } \\
\text { (stems/ } \\
\text { sucrose) }\end{array}$ & $70-80$ & & 2. & 32.4 & NS & NS & 23.4 & 39.3 & NS & 22.8 & 15.1 & 29.1 & 16.2 \\
\hline $\begin{array}{l}\text { Sugar beet } \\
\text { (roots/ } \\
\text { sucrose) }\end{array}$ & 110 & & 3. & 0.7 & NS & 7.9 & NS & NS & 2.9 & 20.7 & NS & NS & NS \\
\hline $\begin{array}{l}\text { Tropical sugar } \\
\text { beet (roots) }\end{array}$ & $\begin{array}{l}\text { 83-94 } \\
\text { (global); } 98 \\
\text { (S. Africa) }\end{array}$ & & 4. & \multicolumn{10}{|c|}{ No data, but yields approaching those of sugarcane have been suggested. } \\
\hline $\begin{array}{l}\text { Soybeans } \\
\text { (seeds) }\end{array}$ & & 205 & 5. & 2.6 & 0.8 & 0.3 & 2.3 & 3.1 & 0.4 & 1.0 & 0.8 & 3.6 & 2.4 \\
\hline $\begin{array}{l}\text { Sunflower } \\
\text { (seeds) }\end{array}$ & & $\begin{array}{l}350 \text { (South } \\
\text { Africa); } \\
427 \text { (EU) }\end{array}$ & 6. & 2.1 & 1.1 & 1.2 & 2.0 & 1.9 & 0.7 & 2.0 & 1.6 & 2.9 & 2.0 \\
\hline $\begin{array}{l}\text { Jatropha } \\
\text { (seeds) }\end{array}$ & & $250-350$ & 7. & 1.8 & NS & NS & 1.6 & 2.3 & NS & 1.2 & 1.2 & 1.6 & 0.9 \\
\hline
\end{tabular}




\begin{tabular}{|c|c|c|c|c|c|c|c|c|c|c|c|c|c|}
\hline $\begin{array}{l}\text { Tobacco } \\
\text { Solaris biotype } \\
\text { (leaves/stalks) }\end{array}$ & NA & & & No c & & & & & & & & & \\
\hline $\begin{array}{l}\text { Tobacco } \\
\text { Solaris biotype } \\
\text { (seeds) }\end{array}$ & & NA & 8. & Noo & but Sc & ican & ys an & oeing & portec & $0 \mathrm{t} / \mathrm{ha}$ & oil fro & $y$ trials & \\
\hline $\begin{array}{l}\text { Tobacco } \\
\text { (Nicotiana } \\
\text { tabacum (L.)) } \\
\text { seed oil (TSO), } \\
\text { a by-product of } \\
\text { tobacco leaf } \\
\text { production }\end{array}$ & 280 & & 9. & 0.8 & 0.4 & 0.4 & 0.8 & 0.8 & 0.2 & 0.6 & 0.5 & 1.0 & 0.7 \\
\hline $\begin{array}{l}\text { Switchgrass } \\
\text { (stems) }\end{array}$ & 273-379 & & 10. & NS & NS & 0.5 & NS & NS & NS & 1.2 & NS & NS & NS \\
\hline $\begin{array}{l}\text { Plantain (peels- } \\
\text { Cellulose/hemi } \\
\text { celluloses) }\end{array}$ & NA & NA & 11. & 1.4 & NS & NS & 1.3 & 1.8 & NS & 1.8 & 0.8 & NS & 0.7 \\
\hline \multicolumn{14}{|c|}{ 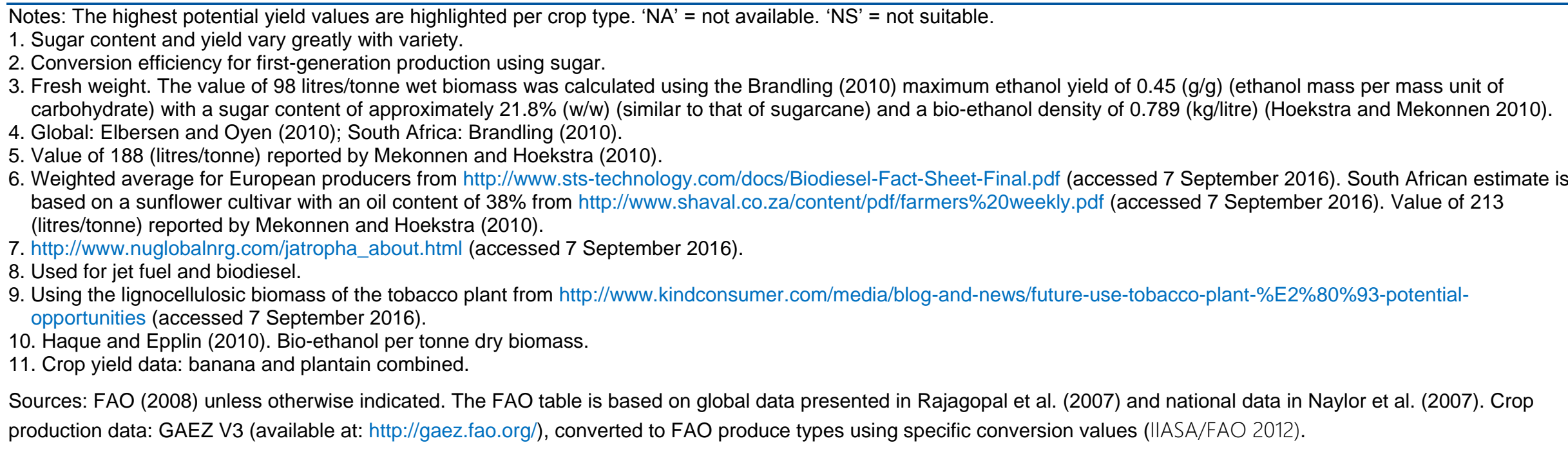 } \\
\hline
\end{tabular}




\section{Current cultivation and yields in the sub-region}

The current (2013) cultivated area as a percentage of the total land surface area (including permanent inland water bodies) in countries in the sub-region varies between 0.5 per cent (in Botswana) and 33.3 (in Malawi) (Table 9). Most countries reported an increase in the area cultivated between 2002 and 2013; Lesotho, South Africa, Namibia, and Swaziland showed a slight decline (Table 9). The total cultivated area is the sum of the area classified as arable land and as permanent crops. Arable land is defined as land under temporary crops (double-cropped areas are counted only once), temporary meadows for mowing or pasture, land under market and kitchen gardens, and land temporarily fallow (less than five years). It does not include abandoned land resulting from shifting cultivation. Permanent crops refers to crops that are sown or planted once and that are not replanted after each annual harvest. For the purpose of this study it was assumed that the area currently cultivated is mainly used for human and animal food production.

Spatial data at a moderate $(25-50 \mathrm{~km})$ or relatively fine $(<25 \mathrm{~km})$ resolution for areas cultivated for food production are sparse or even lacking in some areas. Different groups have attempted during the last decade to generate spatial cropland datasets at a resolution sufficient for decisionmaking at a global, regional, or national level for current climate conditions-(Monfreda et al. 2008 (M3 datasets); Ramankutty et al. 2008 (M3 datasets); Portmann et al. 2010 (MIRCA2000 datasets) Fischer et al. 2000, 2012; IIASA/FAO 2012 (GAEZ V3 datasets); and You et al. 2014 (SPAM datasets))—and future climate conditions (Fischer et al. 2011; Zabel et al. 2014).

The approaches, models, techniques, and input datasets used to generate these spatial datasets differ from each other to varying extents, resulting in different crop results. The reported and simulated (using the M3 and GAEZ datasets) total cultivated areas (i.e. the spatial extent of cropland) in the sub-region are 33,098,000 ha (FAO 2016), 30,632,000 ha (M3: Monfreda et al. 2008), and 35,317,000 ha (GAEZ: Fischer et al. 2011), respectively, for circa 2000 . The GAEZ dataset is the only simulated dataset that does not use the M3 dataset as input. The GAEZ dataset overestimates ( $\sim 6$ per cent) and the M3 dataset underestimates ( $\sim 8$ per cent) the cropland extent in the sub-region when compared with the reported FAO dataset. 
Table 9: Area cultivated per country for each of the countries included in the study area

\begin{tabular}{|c|c|c|c|c|c|}
\hline Country & Area & $\begin{array}{l}\text { 1998-2002 } \\
(2002)\end{array}$ & $\begin{array}{l}\text { 2003-2007 } \\
(2007)\end{array}$ & $\begin{array}{l}\text { 2008-2012 } \\
\text { (2012) }\end{array}$ & $\begin{array}{l}\text { 2013-2017 } \\
(2013)\end{array}$ \\
\hline \multirow[t]{3}{*}{ Angola } & Total area $(x 1,000 \mathrm{ha})$ & 124,670 & 124,670 & 124,670 & 124,670 \\
\hline & $\begin{array}{l}\text { Cultivated area (arable land }+ \\
\text { permanent crops) (x 1,000 ha) }\end{array}$ & 3,390 & 3,690 & 4,990 & 5,190 \\
\hline & $\begin{array}{l}\text { Percentage of total country surface } \\
\text { area cultivated }\end{array}$ & $2.7 \%$ & $3 \%$ & $4 \%$ & $4.2 \%$ \\
\hline \multirow[t]{3}{*}{ Botswana } & Total area $(x 1,000 \mathrm{ha})$ & 58,173 & 58,173 & 58,173 & 58,173 \\
\hline & $\begin{array}{l}\text { Cultivated area (arable land }+ \\
\text { permanent crops) }(\times 1,000 \text { ha) }\end{array}$ & 246 & 184 & 287 & 274 \\
\hline & $\begin{array}{l}\text { Percentage of total country surface } \\
\text { area cultivated }\end{array}$ & $0.4 \%$ & $0.3 \%$ & $0.5 \%$ & $0.5 \%$ \\
\hline \multirow[t]{3}{*}{ Lesotho } & Total area $(x 1,000 \mathrm{ha})$ & 3,036 & 3,036 & 3,036 & 3,036 \\
\hline & $\begin{array}{l}\text { Percentage area (arable land }+ \\
\text { permanent crops) (x 1,000 ha) }\end{array}$ & 304 & 329 & 285 & 252 \\
\hline & $\begin{array}{l}\text { Percentage of total country surface } \\
\text { area cultivated }\end{array}$ & $10 \%$ & $10.8 \%$ & $9.4 \%$ & $8.3 \%$ \\
\hline \multirow[t]{3}{*}{ Malawi } & Total area $(x 1,000$ ha $)$ & 11,848 & 11,848 & 11,848 & 11,848 \\
\hline & $\begin{array}{l}\text { Cultivated area (arable land }+ \\
\text { permanent crops) }(\times 1,000 \text { ha) }\end{array}$ & 2,980 & 3,135 & 3,885 & 3,940 \\
\hline & $\begin{array}{l}\text { Percentage of total country surface } \\
\text { area cultivated }\end{array}$ & $25.2 \%$ & $26.5 \%$ & $32.8 \%$ & $33.3 \%$ \\
\hline \multirow[t]{3}{*}{ Mozambique } & Total area $(x 1,000 \mathrm{ha})$ & 79,938 & 79,938 & 79,938 & 79,938 \\
\hline & $\begin{array}{l}\text { Cultivated area (arable land }+ \\
\text { permanent crops) (x 1,000 ha) }\end{array}$ & 4,700 & 5,450 & 5,950 & 5,950 \\
\hline & $\begin{array}{l}\text { Percentage of total country surface } \\
\text { area cultivated }\end{array}$ & $5.9 \%$ & $6.8 \%$ & $7.4 \%$ & $7.4 \%$ \\
\hline \multirow[t]{3}{*}{ Namibia } & Total area $(x 1,000 \mathrm{ha})$ & 82,429 & 82,429 & 82,429 & 82,429 \\
\hline & $\begin{array}{l}\text { Cultivated area (arable land }+ \\
\text { permanent crops) (x 1,000 ha) }\end{array}$ & 820 & 808 & 809 & 809 \\
\hline & $\begin{array}{l}\text { Percentage of total country surface } \\
\text { area cultivated }\end{array}$ & $1 \%$ & $1 \%$ & $1 \%$ & $1 \%$ \\
\hline \multirow[t]{3}{*}{ South Africa } & Total area (x 1,000 ha) & 121,909 & 121,909 & 121,909 & 121,909 \\
\hline & $\begin{array}{l}\text { Cultivated area (arable land }+ \\
\text { permanent crops) (x 1,000 ha) }\end{array}$ & 14,100 & 12,962 & 12,913 & 12,913 \\
\hline & $\begin{array}{l}\text { Percentage of total country surface } \\
\text { area cultivated }\end{array}$ & $11.6 \%$ & $10.6 \%$ & $10.6 \%$ & $10.6 \%$ \\
\hline \multirow[t]{3}{*}{ Swaziland } & Total area (x 1,000 ha) & 1,736 & 1,736 & 1,736 & 1,736 \\
\hline & $\begin{array}{l}\text { Cultivated area (arable land }+ \\
\text { permanent crops) (x 1,000 ha) }\end{array}$ & 192 & 192 & 190 & 190 \\
\hline & $\begin{array}{l}\text { Percentage of total country surface } \\
\text { area cultivated }\end{array}$ & $11.1 \%$ & $11.1 \%$ & $10.9 \%$ & $10.9 \%$ \\
\hline \multirow[t]{3}{*}{ Zambia } & Total area $(x 1,000 \mathrm{ha})$ & 75,261 & 75,261 & 75,261 & 75,261 \\
\hline & $\begin{array}{l}\text { Cultivated area (arable land }+ \\
\text { permanent crops) }(\times 1,000 \text { ha) }\end{array}$ & 2,616 & 2,984 & 3,836 & 3,736 \\
\hline & $\begin{array}{l}\text { Percentage of total country surface } \\
\text { area cultivated }\end{array}$ & $3.5 \%$ & $4 \%$ & $5.1 \%$ & $5 \%$ \\
\hline \multirow[t]{3}{*}{ Zimbabwe } & Total area $(x 1,000 \mathrm{ha})$ & 39,076 & 39,076 & 39,076 & 39,076 \\
\hline & $\begin{array}{l}\text { Cultivated area (arable land }+ \\
\text { permanent crops) (x 1,000 ha) }\end{array}$ & 3,750 & 4,100 & 4,100 & 4,100 \\
\hline & $\begin{array}{l}\text { Percentage of total country surface } \\
\text { area cultivated }\end{array}$ & $9.6 \%$ & $10.5 \%$ & $10.5 \%$ & $10.5 \%$ \\
\hline Total & Total area $(x 1,000 \mathrm{ha})$ & 598,076 & 598,076 & 598,076 & 598,076 \\
\hline
\end{tabular}




\begin{tabular}{llcccc}
\hline sub-region & $\begin{array}{l}\text { Cultivated area (arable land }+ \\
\text { permanent crops) (x 1,000 ha) }\end{array}$ & 33,098 & 33,834 & 37,245 & 37,354 \\
& $\begin{array}{l}\text { Percentage of total sub-region } \\
\text { surface area cultivated }\end{array}$ & $5.5 \%$ & $5.7 \%$ & $6.2 \%$ & $6.2 \%$ \\
\hline
\end{tabular}

Notes: Data are shown for 5-year intervals. The values are for the latest available year for the 5-year periods (applicable year shown in brackets). The data were simulated and corrected where possible with national and sub-national reported data (HarvestChoice 2015). The data show the minimum and maximum attainable yields based on the simulated (and in some instances validated) data at the sub-national level and highlight the variability in production yields within a country. The spatial variability in yields within each country for the different crop types is shown with boxplots (Figure 21)

Sources: HarvestChoice (2015) spatially disaggregated production statistics of circa 2005 using the Spatial Production Allocation Model (SPAM) (You et al. 2014), available online at: http://harvestchoice.org/; FAO (2016); AQUASTAT Main Database - Food and Agriculture Organization of the United Nations (available at: www.fao.org/nr/water/aquastat/data/; accessed 4 August 2016). 
Figure 21: Boxplots of the spatial variability in crop yields under irrigated and rainfed conditions at the national level for each of the countries in the study area

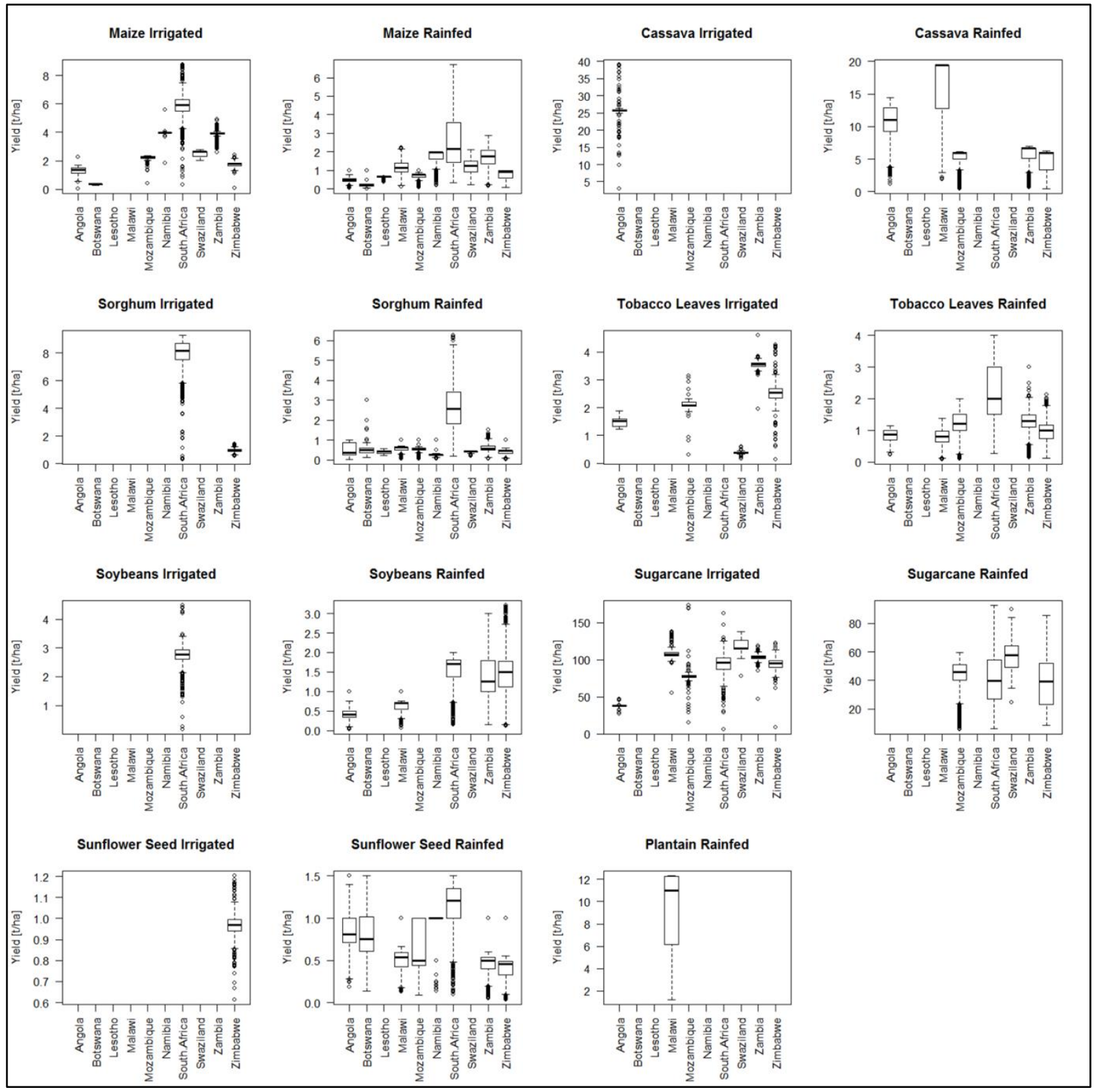

Notes: The y-axes vary in ranges, and countries are listed in alphabetical order. Empty columns indicate the absence of the cultivation of a specific crop within a country.

Source: HarvestChoice (2015) (available at: http://harvestchoice.org/data/).

Cassava, sorghum, sunflower seeds, soybean, and plantain are mainly or only produced under rainfed conditions, in contrast to sugarcane, which is mainly irrigated within the sub-region.

- South Africa produces on average the highest median maize yield, i.e. about $6 \mathrm{t} / \mathrm{ha}$. Values of above $8 \mathrm{t} / \mathrm{ha}$ can also occur under irrigated conditions.

- Cassava yields of $25 \mathrm{t} / \mathrm{ha}$ and higher are possible under irrigated conditions, as is the case for Angola, whereas median yields of 10-20 t/ha occur in Angola and Malawi under rainfed conditions.

- South Africa has the highest sorghum yields under both rainfed $(>2 \mathrm{t} / \mathrm{ha})$ and irrigated $(>8 \mathrm{t} / \mathrm{ha}$ ) conditions. 
- Yields of $>3 \mathrm{t} / \mathrm{ha}$ of tobacco leaves are consistent throughout Zambia under irrigated conditions, whereas the highest yields under rainfed conditions occur in South Africa (2$4 \mathrm{t} / \mathrm{ha})$.

- South Africa is the only country that uses irrigation for soybean, resulting in median yields of close to $3 \mathrm{t} / \mathrm{ha}$, with yields $>4 \mathrm{t} / \mathrm{ha}$ possible. Rainfed yields of soybean are on average $1-2 \mathrm{t} / \mathrm{ha}$ and yields of $\geq 3 \mathrm{t} / \mathrm{ha}$ are possible in Zimbabwe and Zambia.

- Sugarcane produces the highest biomass yields of all the crop types considered. Swaziland, Malawi, and Zambia produce the highest sugarcane yields in the sub-region. Swaziland produces on average the highest sugarcane yields, i.e. $\sim 120 \mathrm{t} /$ ha under irrigated and close to $60 \mathrm{t} / \mathrm{ha}$ under rainfed conditions. Malawi and Zambia produce close to $100 \mathrm{t} / \mathrm{ha}$ under irrigated conditions.

- Sunflower fields are irrigated only in Zimbabwe according to the HarvestChoice (2015) dataset, with median yields of about $1 \mathrm{t} / \mathrm{ha}$. Sunflower seed yields of greater than $1 \mathrm{t} / \mathrm{ha}$ occur in South Africa under rainfed conditions.

- According to the HarvestChoice (2015) dataset, plantain is harvested only in Malawi, with a median yield of 10-12 t/ha, and is cultivated only under rainfed conditions.

The general national trends in the mean yields per crop type reported to the FAO on a yearly basis are shown in Figure 22. Trends are shown for the period 2000-2013 using a locally weighted least squares regression (LOESS) function with a 95 per cent confidence interval. A non-linear regression fit line was selected in order to capture the fluctuations in the data. The data are from the FAO and available at http://faostat3.fao.org. Mean country level t/ha data are plotted per country and for each potential biofuel crop type cultivated within a country. Plots are also shown for the mean global yield values per crop type. Figure 22 is spread over multiple pages. For visualization purposes, sugarcane, sugar beet, and cassava are plotted separately due to the order of magnitude differences of yield values for these crops compared with the other crops.

Yield values are higher in 2013 than in 2000 for the individual crops and in general an upward trend can be observed throughout the period 2000-2013. The exceptions are sugarcane and cassava, which show a decline since 2009 and 2011, respectively. The 14-year national trend patterns for the four major biofuel crop types, i.e. maize, cassava, sugarcane, and sorghum, can be summarized as follows:

- A comparison between the 2000 and 2013 values indicates that maize yields are generally increasing in Angola, Malawi, South Africa, and Zambia. However, yields in these countries reached maximum values prior to 2013, with declining yield values observed during the last five years-most likely as a result of the large-scale drought experienced during the latter part of 2008-2013 in the sub-region.

- Cassava yields show a steady increase in Malawi and a steady decrease in Zambia compared with fluctuating yield values in other cassava-producing countries in the sub-region during the 2000-2013 period.

- Sugarcane production yields show a general increase in Angola and Mozambique for the whole of the 2000-2013 period. Most of the other countries show steep declines in yields after 2011, with the exception of Zimbabwe and Swaziland, where sugarcane yields increased over the same period.

- Sorghum yields show a long-term increase only in Malawi and Swaziland, while yields have declined in the other countries. The decline is also observed in South Africa and Zimbabwe, where fields are irrigated (see Figure 24 to determine which countries irrigate sorghum fields). 
Figure 22: Trends in crop yields for the period 2000-2013
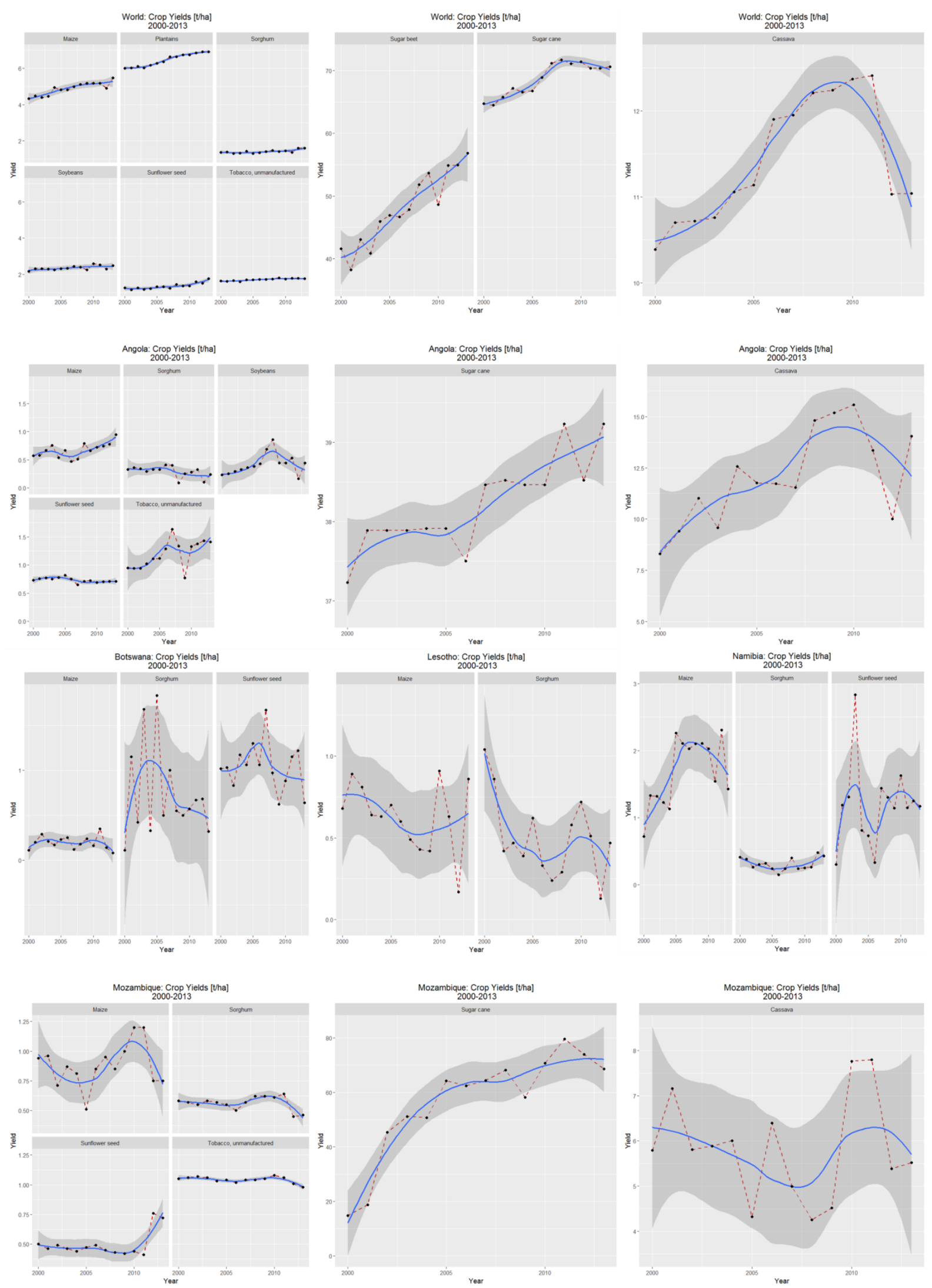

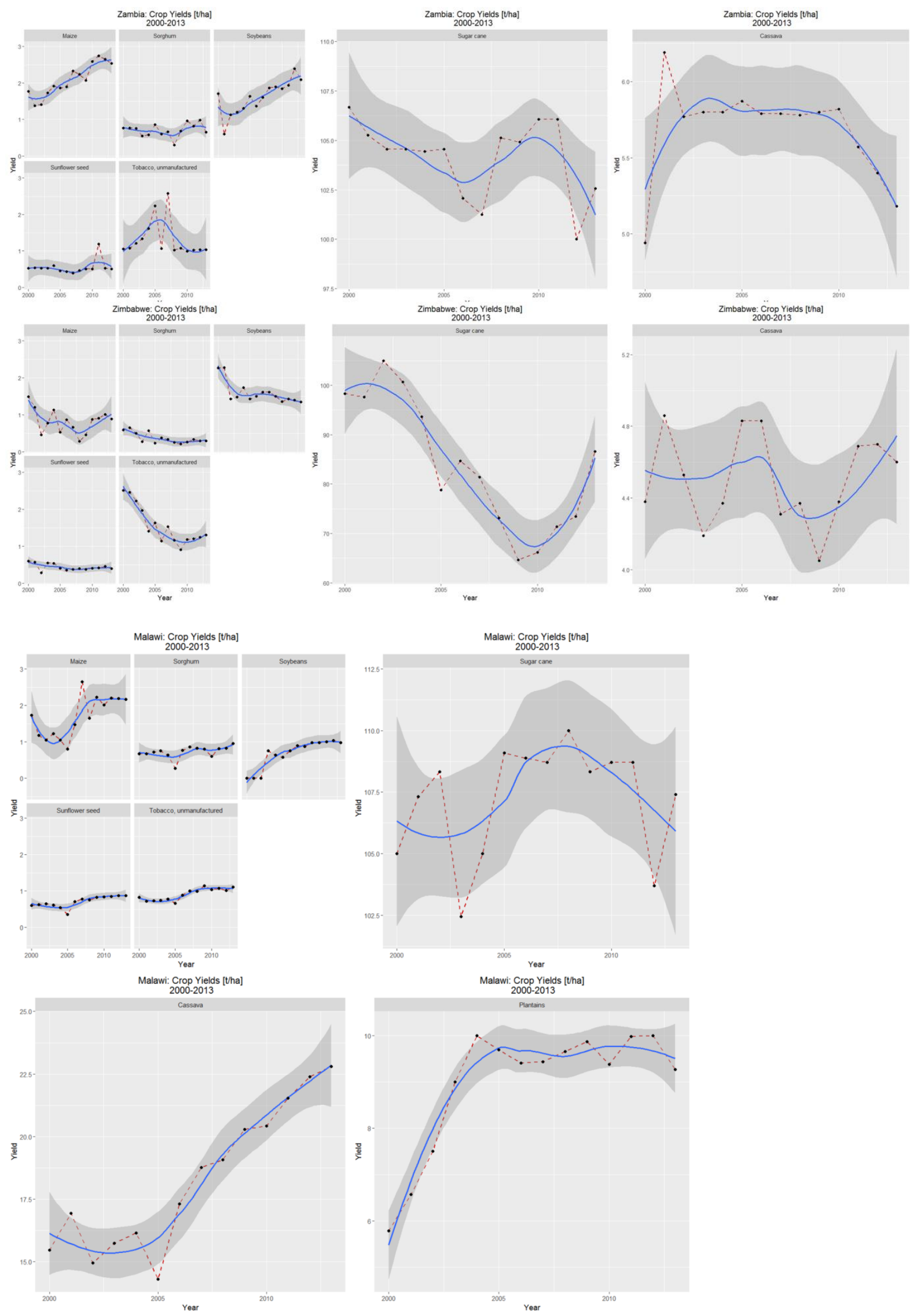

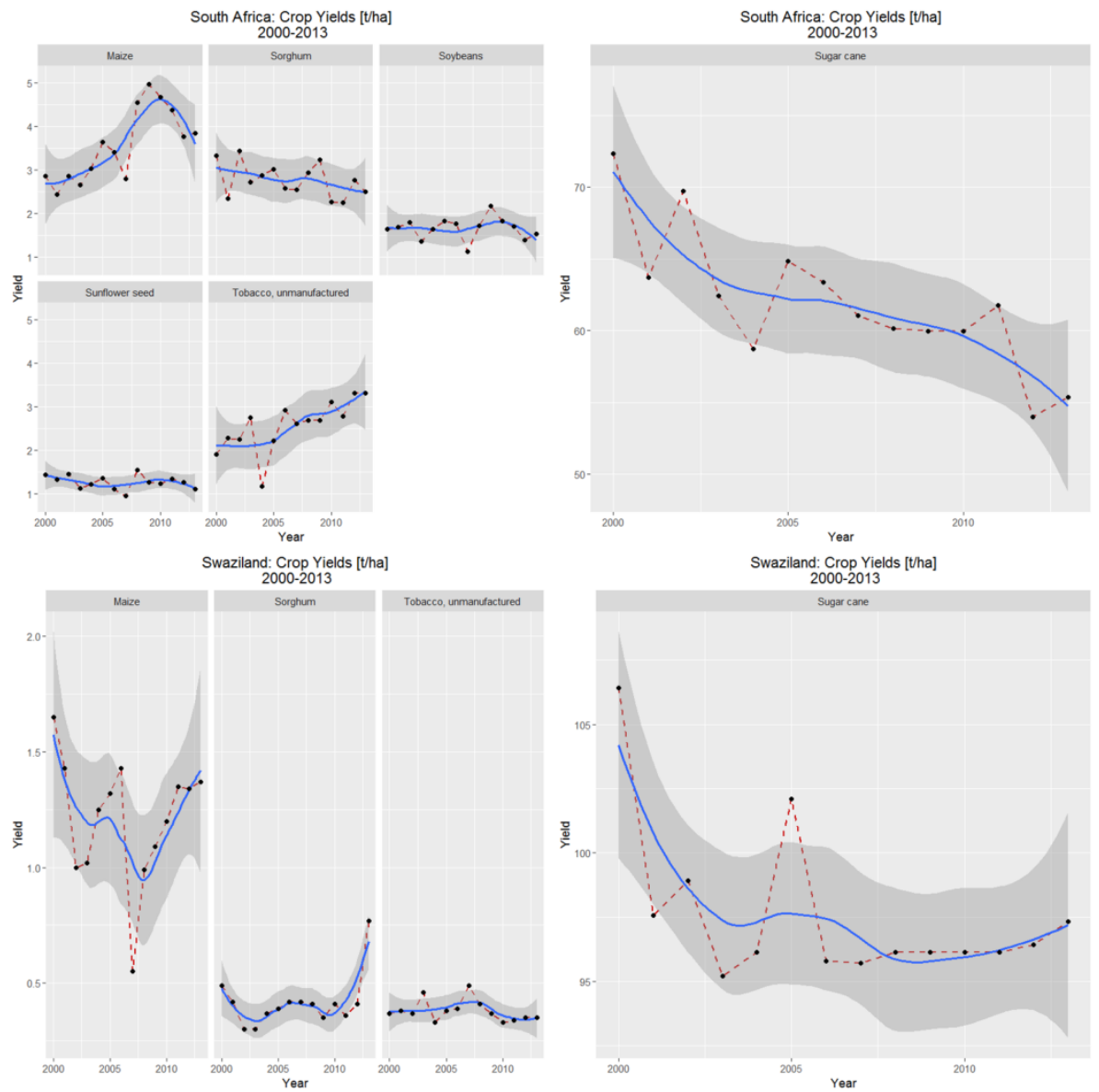

Notes: The 95\% confidence intervals are shown for the LOESS fit lines. The y-axes show varying ranges. Graphs for crops with order of magnitude differences in the yield values are plotted separately for visualization purposes.

Source: GAEZ V3 (available at: http://gaez.fao.org/), converted to FAO produce types using specific conversion values (IIASA/FAO 2012).

The cropland and pasture spatial extent datasets (Ramankutty et al. 2008) are plotted in Figure 23. The cropland and pasture datasets were checked to ensure that the per pixel totals of the cropland and pasture do not exceed the value of 1.0 (i.e. 100 per cent). Areas classified as pasture cover large parts of the sub-region but these areas do not necessarily exclude potential crop cultivation under suitable climate and soil conditions and farming practices. 


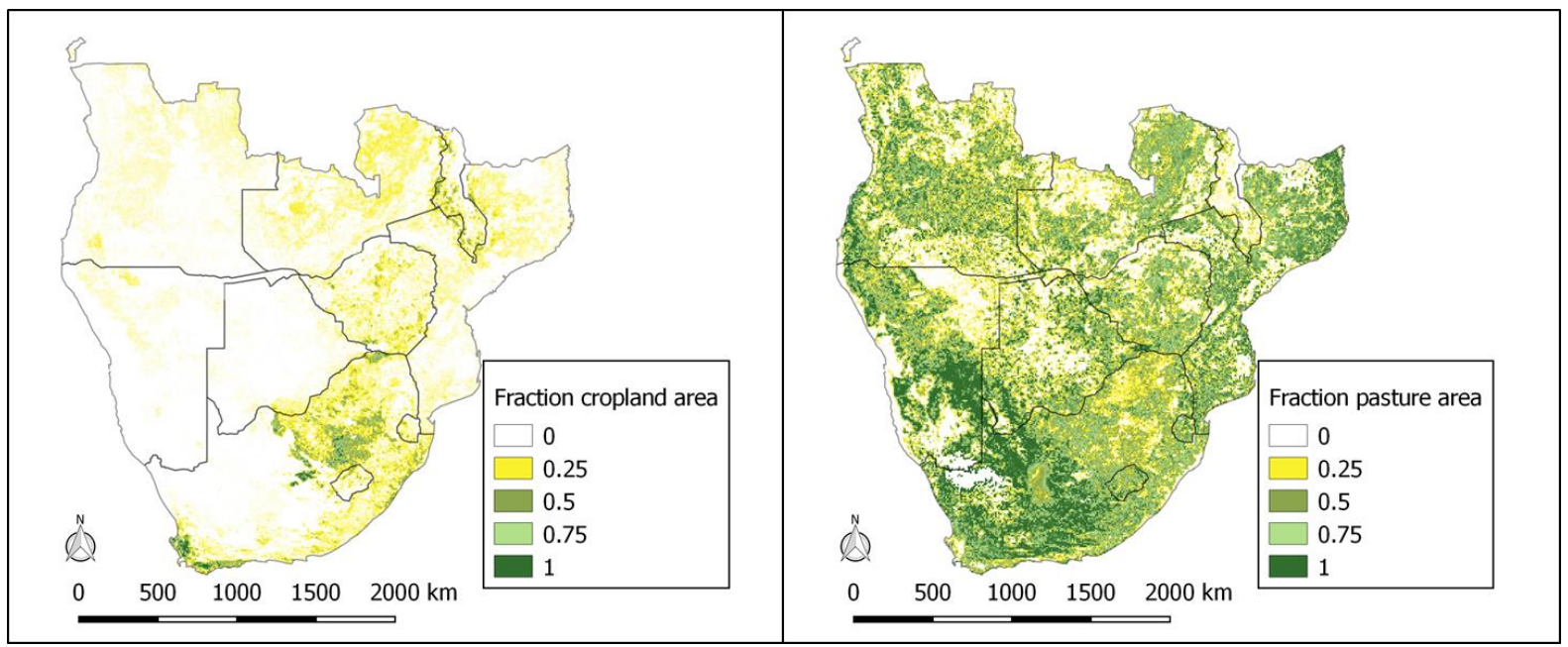

Note: Data are shown for a $0.08333^{\circ}$ resolution for circa 2000.

Source: Ramankutty et al. (2008); data available from Earthstat (http://www.earthstat.org/).

\section{$5 \quad$ Potential for biofuel crops}

The spatial representation of the available historical and future crop data is explored in this section. The simulated historical and/or current spatial crop datasets should in theory correspond to the reported national and sub-national crop data as well as agree between different models. This is, however, not always the case, one of the reasons being the use of different or modified versions of existing cropland datasets as input. The GAEZ model is the only model presented in this report that does not use the M3 (Monfreda et al. 2008) dataset as input. It relies on an extensive analysis of crop-specific agro-climatic and edaphic suitability (Anderson et al. 2015).

For biofuel production it is important that high yields are obtained. It is therefore assumed that, if crops are grown for biofuel, they will be grown under high input levels with high management input. Experience from the sugarcane industry shows that this level of management can be achieved throughout the region where industrial crops are concerned. A key feature of the Southern African region is the huge gap between current crop yields and the yields that could be achieved under good management conditions with appropriate fertilizer application. For instance, where most Zambian smallholder maize farmers are achieving yields of only $1-2 \mathrm{t} / \mathrm{ha}$ for maize, under high input levels the agronomy models suggest that yields of $10 \mathrm{t} / \mathrm{ha}$ or more (as are being routinely achieved in the USA) should be possible.

The FAO/GAEZ and SPAM models were used to assess suitable growing areas and potential yields for a variety of potential biofuel crops. The FAO/GAEZ model was found to better represent known growth areas and only these results are presented. Outputs for select crops, showing both crop suitability and yield results, are shown in Figures 24-26.

A consistent pattern emerges for most crops in the sense that northern Mozambique and northern Zambia tend to have good potential for almost all crops. The east coast of South Africa also tends to have a high suitability for the less tropical crops, while the South African interior has high suitability for some crops. The modelled data also indicate that potential yields may, in some cases, be close to a full order of magnitude greater than current reported yields. 
Figure 24: Agro-ecological suitability and productivity of maize, sorghum (grain), jatropha, and soybean based on long-term climate conditions (1961-1990), a high-input management level, and rainfed conditions

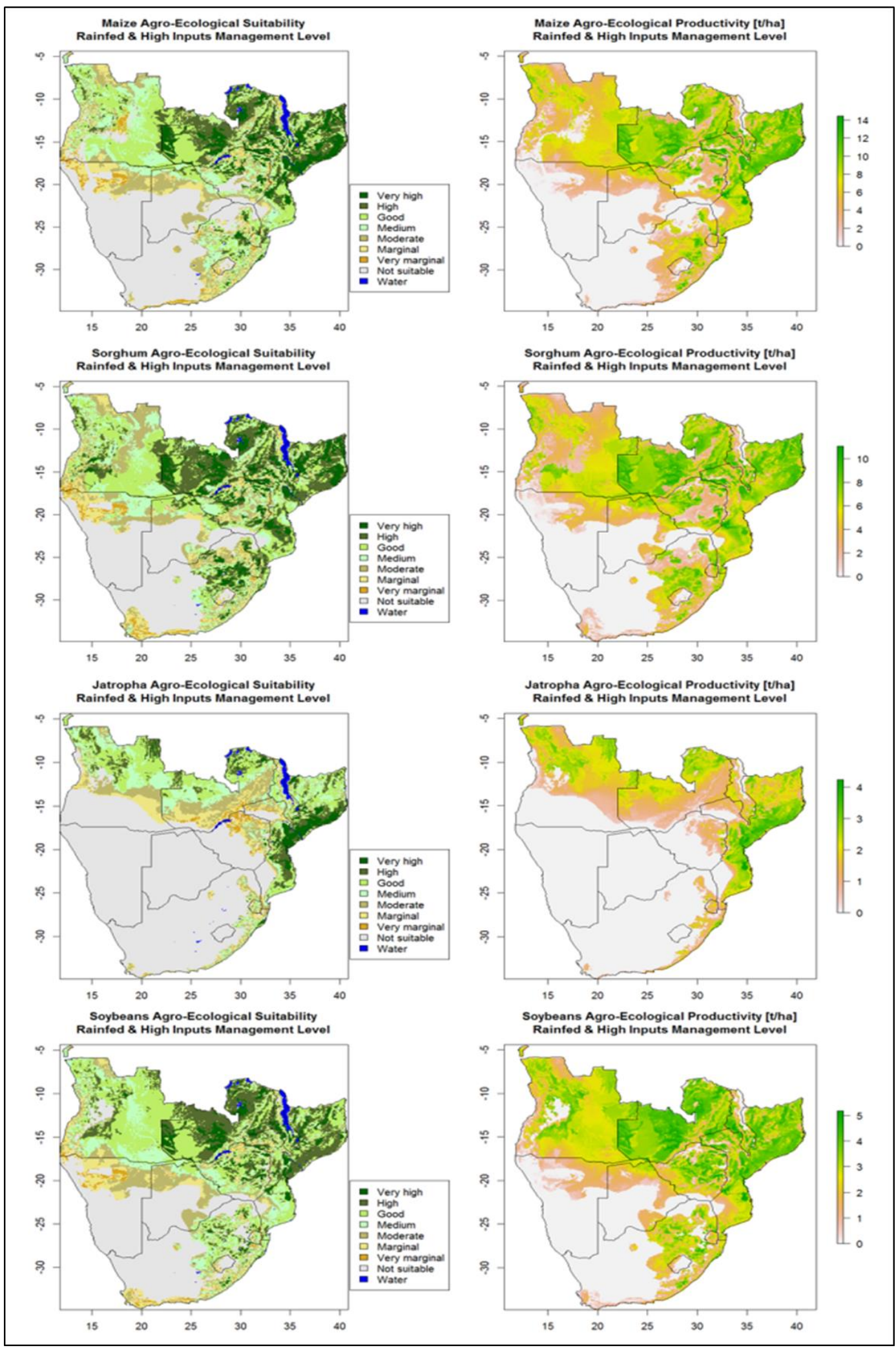

Source: IIASA/FAO (2012) (available at: http://gaez.fao.org/). 
Figure 25: Agro-ecological suitability and productivity of sugar beet (not tropical), sugarcane, cassava, and switchgrass based on long-term climate conditions (1961-1990), a high-input management level, and rainfed conditions

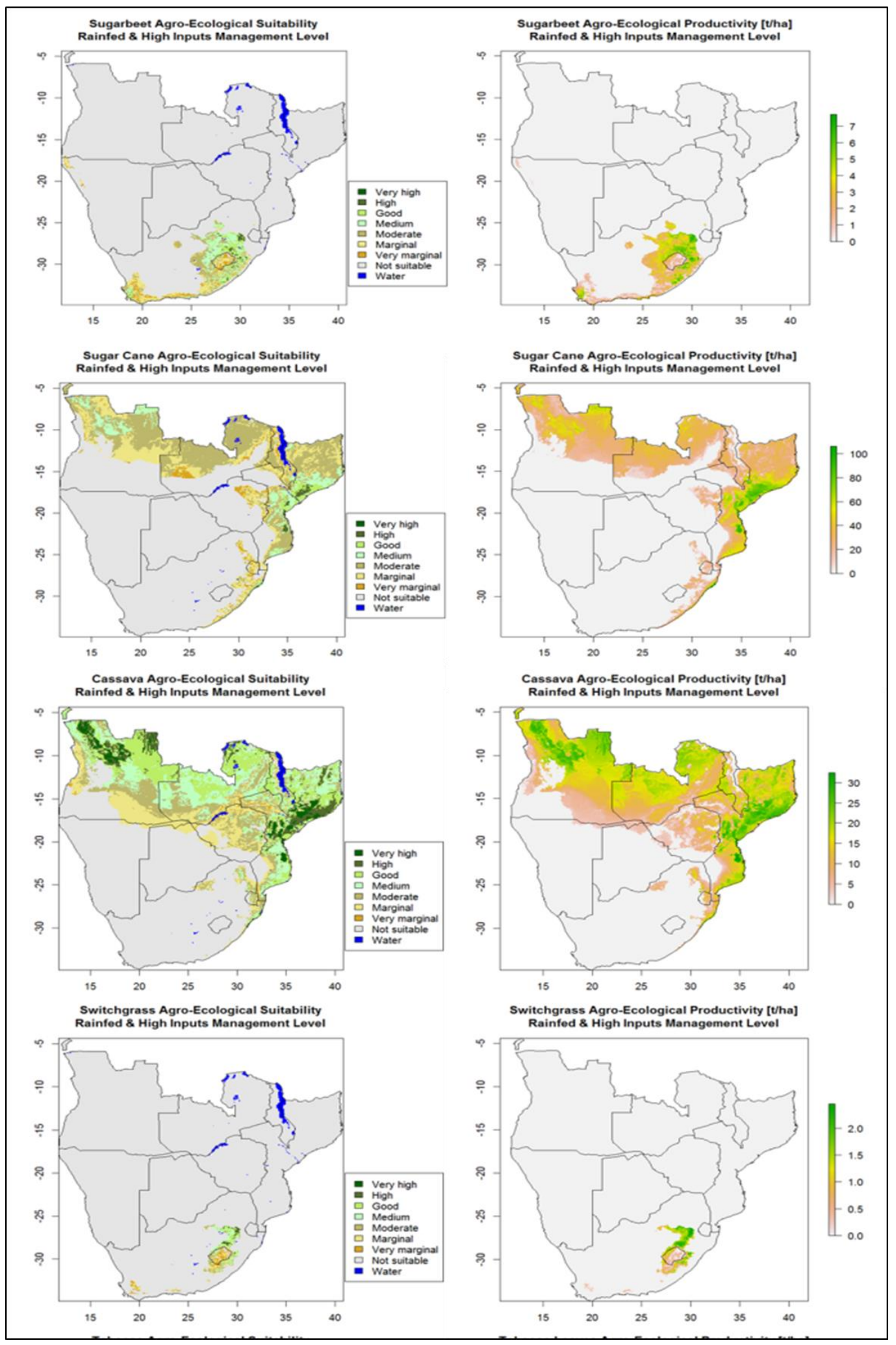

Note: Grey areas are unsuitable for the cultivation of the specific crop.

Source: IIASA/FAO (2012) (available at: http://gaez.fao.org/). 
Figure 26: Agro-ecological suitability and productivity of tobacco (leaf) and sunflower based on long-term climate conditions (1961-1990), a high-input management level, and rainfed conditions

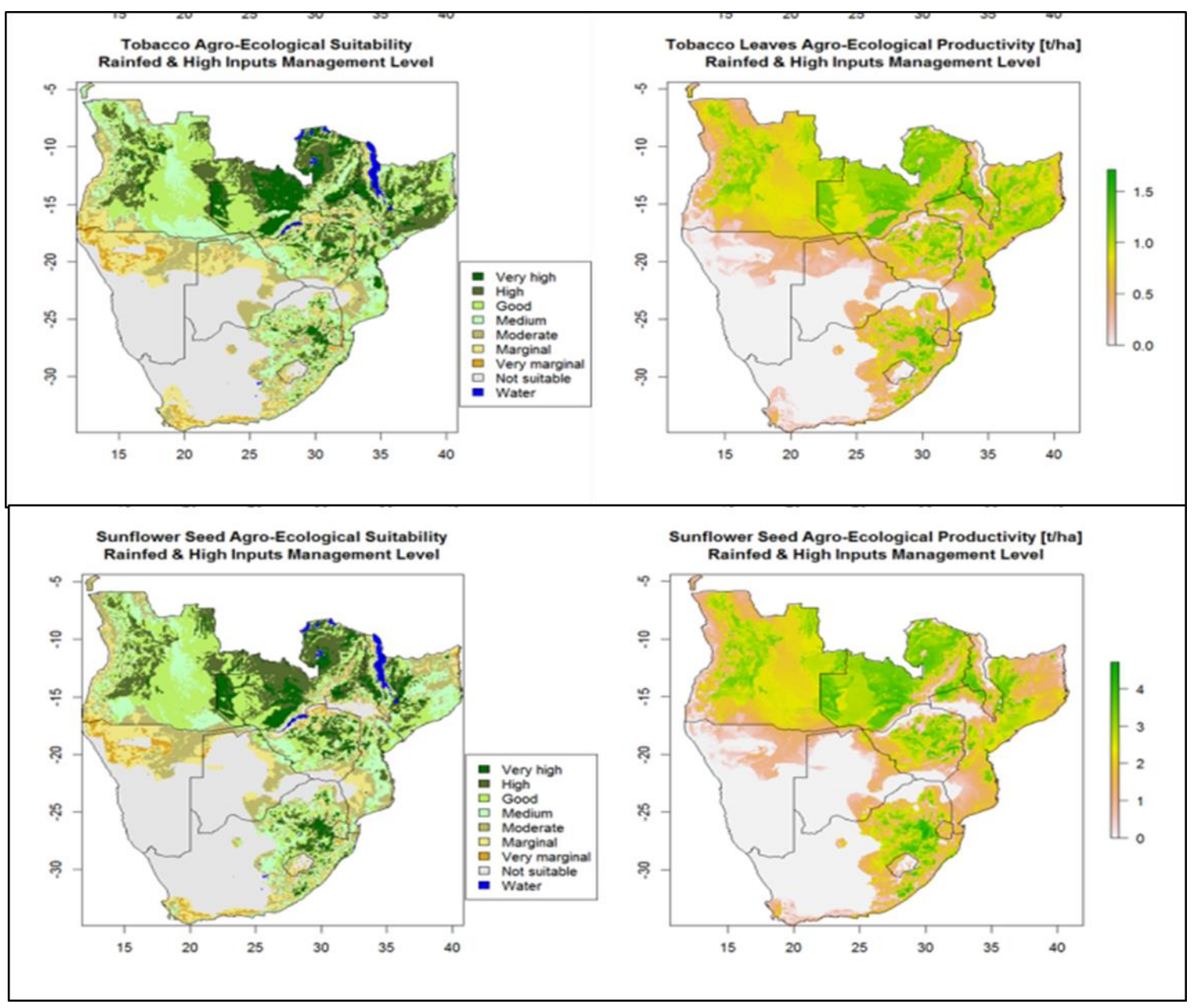

Note: Grey areas are unsuitable for the cultivation of the specific crop.

Source: IIASA/FAO (2012) (available at: http://gaez.fao.org/).

Sugarcane has a relatively limited distribution for dryland production, but huge potential if irrigation is available. It is largely the long dry winters that limit widespread expansion of sugarcane in areas other than the east coast.

A number of crops do not have well developed production models. For instance, we could not find a specific model for tropical sugar beet. The temperate sugar beet model that was used (Figure 24) limits the sugar beet to a more temperate range than would be expected for tropical beet, which is reported also to grow well in hot climates such as Bangladesh. We believe that tropical beet's range may well extend throughout the region where sufficient rainfall is available, but this would require field tests.

No specific data could be obtained for sweet sorghum, and the data as presented are for seed sorghum. It is assumed that both have a similar distribution range, though it is likely that it is only in higher rainfall areas that sweet sorghum will have sufficient per hectare yield to be suitable as a biofuel crop.

Jatropha yield should be ignored, as field experience has seldom reached even $1 \mathrm{t} / \mathrm{ha}$ in the region. 
For tobacco, it is assumed that areas with good leaf tobacco-growing ability may well be suited to seed tobacco. This has not been verified, and since seed tobacco is in effect a new crop, it should be extensively field-tested before being considered.

\section{Conclusions}

From a biophysical perspective much of Southern Africa has high biofuel production potential. The arid south-west makes large areas of South Africa as well as most of Namibia and Botswana unsuitable for rainfed agriculture. These same areas also have a large number of soil constraints and mostly experience cold winters. The deep sands of the extensive Kalahari basin mean that even relatively moist areas of Angola have limited production potential.

On the other hand, the high-rainfall areas in South Africa (mostly in the mountains and along the east coast) are suitable for biofuel crops. And vast areas of Mozambique, Zimbabwe, and Zambia appear to be suitable for biofuel production from both a climatic and soils perspective.

A number of biofuel crops appear to have good potential for exploitation in the region. For firstgeneration ethanol production, sugarcane is a proven crop with good yields, especially when receiving supplementary irrigation. Without irrigation the growth potential of sugarcane is restricted to a few areas, mostly in central Mozambique, in Malawi, and along the South African east coast.

Alternative first-generation sugar crops that may replace sugarcane are sweet sorghum and/or tropical sugar beet. Both these crop are more water-use-efficient than sugarcane, but both need extensive testing in the region before they can be selected for large-scale implementation.

As a first-generation starch crop for ethanol, cassava appears to have good potential. Cassava tends to be a low-altitude crop able to grow in areas too tropical for many other starch crops.

Maize as a biofuel crop is a potential option in Mozambique and Zambia, where agronomic models suggest that high yields could be achieved under high management input. However, the use of maize is a sensitive issue due to food-fuel conflict concerns. Grain sorghum also has a potential as a first-generation starch crop, though estimated yields are far lower than for maize.

Among first-generation oil crops for biodiesel, soybean and seed tobacco seem to be the best options. Soybean oil would, however, be competing strongly with food markets, which are likely to pay more for the oil. A new variety of oilseed tobacco is being tested in South Africa and early results are very promising.

For second-generation feedstocks there are a number of options. The common options being promoted in America, i.e. miscanthus and switchgrass, appear to be poorly suited to the region, other than in the more temperate Eastern Cape region of South Africa. Among fast-growing biomass crops, biomass sorghum and sugarcane are potential options. Among perennial crops, eucalyptus species have a proven yield.

Closing the gap between current and potential yields for all crops other than sugarcane would be an important challenge. Experience from the sugar sector suggests that with the correct support and market access, both small- and large-scale farmers should be able to produce crops at yields that are among the world's best. 


\section{References}

Almodares, A., and M.R. Hadi (2009). 'Production of Bioethanol from Sweet Sorghum: A Review'. African Journal of Agricultural Research, 4(9): 772-80. Available at: http://www.academicjournals.org/AJAR.

Almodares, A., and M.S. Hatamipour (2011). 'Planting Sweet Sorghum under Hot and Dry Climatic Conditions for Bioethanol Production'. Paper presented at the World Renewable Energy Congress 2011, Sweden.

Anderson, W., L. You, S. Wood, U. Wood-Sichra, and W. Wu (2015). 'An Analysis of Methodological and Spatial Differences in Global Cropping Systems Models and Maps'. Global Ecology and Biogeography, 24: 180-91. Doi: 10.1111/geb.12243.

AQUASTAT (2010). 'Country Profile: Angola'. Rome: FAO. Available at: http://www.fao.org/nr/water/aquastat/countries_regions (accessed 22 February 2017).

Bitzer, M. (2009). 'Early Deheading of Sweet Sorghum'. Research Report. National Sweet Sorghum Producers and Processors Association.

Brandling, J.E. (2010). 'Production of Ethanol from Tropical Sugar Beet'. MSc Thesis, Potchefstroom Campus of the University of the North West, South Africa.

Butchee, K., D.B. Arnall, A. Sutradhar, C. Godsey, H. Zhang, and C. Penn (2012). 'Determining Critical Soil $\mathrm{pH}$ for grain sorghum production," International Journal of Agronomy, vol. 2012, Article ID 130254, 6 pages, 2012.

Curt, M., J. Fernandez, and M. Martinez (1998). 'Productivity and Radiation Use Efficiency of Sweet Sorghum (Sorghum bicolor (L.) Moench) cv. Keller in Central Spain'. Biomass and Bioenergy, 14(2): 169-78. Doi: 10.1016/S0961-9534(97)10025-3.

DAFF (Department of Agriculture, Forestry and Fisheries) (2016). 'Abstract of Agricultural Statistics 2016'. Available at: http://www.daff.gov.za/Daffweb3/Portals/0/Statistics $\% 20$ and $\% 20$ Economic $\% 20$ Analysis /Statistical\%20Information/Abstract\%202016\%20.pdf (accessed March 2017).

DNHA (Direccão nacional de hidraulica agricola) (2003). 'Sínteso do Levantamento nacional dos regadios 2001 e 2003'. Maputo: Ministry of Agriculture and Rural Development. Republic of Mozambique.

Du Plessis, J. (2008). Sorghum Production. Department of Agriculture, Republic of South Africa. Available at: http://www.daff.gov.za/docs/Infopaks/FieldCrops_Sorghum.pdf (accessed: 8 March 2017).

Duke, J.A. (1983). Handbook of Energy Crops. Center for New Crops and Plants Products, Purdue University. Available at: http://www.hort.purdue.edu/newcrop/Indices/index_ab.html (accessed 23 May 2016).

Elbersen, W., and L. Oyen (2010). 'Tropical Sugar Beet (Beta vulgaris L.) Potential of Tropical Sugar Beet for Bio-ethanol Production'. Project 146/WW/001. FACT Foundation. Available at: https://msibsri4313.files.wordpress.com/2013/11/factsheet-tropical-sugarbeet.pdf (accessed 22 February 2017).

FAO (2001). 'Global Forest Resource Assessment'. FAO Forestry Paper 140. Rome: FAO. ftp://ftp.fao.org/docrep/fao/003/y1997e/fra\%202000\%20main\%20report.pdf (accessed 25 March 2017).

FAO (2006). Ecocrop info. Available at: http:// ecocrop.fao.org (accessed April 2016). 
FAO (2008). 'Biofuels and Agriculture - A Technical Overview'. In The State of Food and Agriculture 2008: Biofuels: Prospects, Risks and Opportunities. Published by the Agricultural and Development Economics Division (ESA) on behalf of the Food and Agriculture Organization (FAO) of the United Nations. Available at: http://www.fao.org/docrep/011/i0100e/i0100e00.htm (accessed 23 March 2017).

FAO (2013). 'FAO Agricultural Production Statistics for 2011'. Available at: www.FAOstat.fao.org (accessed July 2013).

FAO (2016). AQUASTAT website. Food and Agriculture Organization of the United Nations (FAO). Available at: www.fao.org/nr/aquastat/(accessed 4 August 2016).

Fermont, A., P. van Asten, P. Tittonell, M. van Wijk, and K. Giller (2009). 'Closing the Cassava Yield Gap: An Analysis from Smallholder Farms in East Africa'. Field Crops Research, 112(1): 24-36.

Fischer, G., H.T. van Velthuizen, and F.O. Nachtergaele (2000). 'Global Agro-Ecological Zones Assessment: Methodology and Results'. IIASA Interim Report IR-00-064. Laxenburg, Austria: IIASA.

Fischer, G., F. Nachtergaele, S. Prieler, H.T. van Velthuizen, L. Verelst, and D. Wiberg (2008). Global Agro-ecological Zones Assessment for Agriculture (GAEZ 2008). Laxenburg, Austria; IIASA; Rome: FAO.

Fischer, G., F.O. Nachtergaele, S. Prieler, E. Teixeira, G. Tóth, H. van Velthuizen, L. Verelst, and D. Wiberg (2012). 'Global Agro-ecological Zones (GAEZ 3.0): Model documentation'. Available http://www.fao.org/fileadmin/user_upload/gaez/docs/GAEZ_Model_Documentation.p df (accessed 23 March 2017).

Gnansounou, E, A. Dauriat, and C.E. Wyman (2005). 'Refining Sweet Sorghum to Ethanol and Sugar: Economic Trade-offs in the Context of North China’. Bioresour Technol., 96: 985-1002.

Gosse, G. (1996). 'Sweet Sorghum, a Crop for Industry and Energy Supply'. AIR1 CT 92-0041. Brussels: European Commission (DG XII).

Haque, M., and F.M. Epplin (2010). 'Switchgrass to Ethanol: A Field to Fuel Approach'. Paper Prepared for Presentation at the Agricultural \& Applied Economics Association 2010 AAEA, CAES, \& WAEA Joint Annual Meeting, Denver, Colorado, July 25-27.

HarvestChoice (2015). 'Travel Time to Nearest Port (hours, 2000)'. HarvestChoice/International Food Policy Research Institute (IFPRI), Washington, DC., and University of Minnesota, St. Paul, MN. Available at: https:// harvestchoice.org/data/tt_port (accessed 23 March 2017).

Hoekstra, A.Y., and M.M. Mekonnen (2010). 'The Green, Blue and Grey Water Footprint of Crops and Derived Crop Products'. Value of Water Research Report Series 47. Delft, Netherlands: UNESCO-IHE.

IIASA/FAO (2012). 'Global Agro-ecological Zones (GAEZ v3.0)'. Laxenburg, Austria: IIASA; Rome: FAO.

Islam, M.S., S. Ahmad, M.N. Uddin, and M.A. Sattar (2012). 'Evaluation of Tropical Sugarbeet (Beta vulgaris L.) Genotypes under Bangladesh Condition' [sic]. Bangladesh J. Agril. Res., 37(4): 721-28. Available at: www.banglajol.info/index.php/BJAR/article/viewFile/14396/10235 (accessed 22 February 2017).

IUCN (2009). Guidelines on Biofuels and Invasive Species. Gland. Switzerland: International Union for Conservation of Nature. 
Jewitt, G.P.W., H.W. Wen, R.P. Kunz, and A.M. van Rooyen (2009). 'Scoping Study on Water Use of Crops/Trees for Biofuels in South Africa'. WRC Report 1772/1/09.

Khawaja, C. (2014). Energy Sorghum: An alternative Energy Crop: A Handbook. Munich: WIP Renewable Energies.

Available

at: http:// oar.icrisat.org/9049/1/Sweetfuel\%20Handbook\%20English\%20version.pdf (accessed 23 March 2017).

Middleton, N.J., and D.S.G. Thomas (1997). World Atlas of Desertification 2ED. London: Arnold.

Monfreda, C., N. Ramankutty, and J.A. Foley (2008). 'Farming the Planet: 2. Geographic Distribution of Crop Areas, Yields, Physiological Types and Net Primary Production in the Year 2000'. Global Biogeochemical Cycles 22, GB1022. Doi: 10.1029/2007GB002952.

Naylor, R.L., A. Liska, M.B. Marshall, W.P. Falcon, J.C. Gaskell, S.C. Rozelle, and K.G. Cassman (2007). 'The Ripple Effect: Biofuels, Food Security, and the Environment'. Agronomy \& Horticulture, Faculty Publications Paper 386. Available at: http:/ / digitalcommons.unl.edu/agronomyfacpub/386 (accessed 23 March 2017)

Peacock, J.M. (1982). 'Response and Tolerance of Sorghum to Temperature Stress'. In L.R. House et al. (eds), Sorghum in the Eighties. Proceedings of the International Symposium on Sorghum, Patancheru, India, November 2-7, 1981. Hyderabad, India: International Crops Research Institute for the Semi-Arid Tropics (ICRISAT), pp. 143-59.

Portmann, F.T., S. Siebert, and P. Döll (2010). 'MIRCA2000 - Global Monthly Irrigated and Rainfed Crop Areas around the Year 2000: A New High-resolution Dataset for Agricultural and Hydrological Modeling'. Global Biogeochemical Cycles, 24, GB 1011. Doi: 10.1029/2007GB002947.

Rajagopal, D., S.E. Sexton, D. Roland-Host, and D. Zilberman (2007). 'Challenge of Biofuel: Filling the Tank without Emptying the Stomach?' Environ. Res. Lett. 2(4). Available at: http://iopscience.iop.org/article/10.1088/1748-9326/2/4/044004 (accessed 23 March 2017).

Ramankutty, N., A.T. Evan, C. Monfreda, and J.A. Foley (2008). 'Farming the Planet: 1. Geographic Distribution of Global Agricultural Lands in the Year 2000'. Global Biogeochemical Cycles 22, GB1003. Doi: 10.1029/2007GB002952.

Reddy, B.V.S., S. Ramesh, A. Ashok Kumar, and C.L.L. Gowda (2008). 'Sorghum Improvement in the New Millennium'. Andhra Pradesh, India: International Crops Research Institute for the Semi-Arid Tropics.

Schulze, R.E., M. Maharaj, M.L. Warburton, C.J. Gers, M.J.C. Horan, and R.P. Kunz (2007). 'South African Atlas of Climatology and Agrohydrology'. WRC Report 1489(1):06. Pretoria: Water Research Commission.

Sebastian, K. (ed.) (2014). Atlas of African Agriculture Research and Development: Revealing Agriculture's Place in Africa. Washington, DC: International Food Policy Research Institute. Available at: http://dx.doi.org/10.2499/9780896298460 (accessed 23 March 2017).

Smith, C.W., and R.A. Frederiksen (2000). Sorghum: Origin, History, Technology, and Production. New York: John Wiley and Sons.

Srinivasa Rao, P., C. Ganesh Kumar, and B.V.S. Reddy (2014). 'Sweet Sorghum, from Theory to Practice'. In P. Srinivasa Rao and C. Ganesh Kumar (eds), Characterisation of Improved Sweet Sorghum Cultivars. New Delhi: Springer, pp. 1-17. 
Tamil Nadu Agricultural University (n.d.). 'Tropical Sugar Beet: Production Technology'. Available at: http://vikaspedia.in/energy/energy-production/bio-energy/sugarbeet (accessed 30 November 2016).

Trabucco, A., and R.J. Zomer (2009). 'Global Aridity Index (Global-Aridity) and Global Potential Evapo-Transpiration (Global-PET) Geospatial Database'. CGIAR Consortium for Spatial Information. Available at: http://www.cgiar-csi.org/data (accessed 22 February 2017).

Trabucco, A., and R.J. Zomer (2010). 'Global High-resolution Soil-Water Balance Geospatial Database'. CGIAR Consortium for Spatial Information. Available at: http://www.cgiarcsi.org/data (accessed 22 February 2017).

von Maltitz, G.P., A. Gasparatos, and C. Fabricius (2014). 'The Rise, Fall and Potential Resilience Benefits of Jatropha in Southern Africa'. Sustainability, 6(6): 3615-43. Doi: $10.3390 /$ su6063615.

von Maltitz, G.P., A. Gasparatos, C. Fabricius, A. Morris, and K. J. Willis (2016). Jatropha Cultivation in Malawi and Mozambique: Impact on Ecosystem Services, Local Human Wellbeing, and Poverty Alleviation'. Ecology and Society, 21(3). Available at: http:/ / dx.doi.org/10.5751/ES-08554-210303 (accessed 23 March 2017).

Yamori, W., K. Hikosaka, and D.A. Way (2014). 'Temperature Response of Photosynthesis in C3, C4, and CAM Plants: Temperature Acclimation and Temperature Adaptation'. Photosynth Res., 119: 101-17.

You, L., S. Wood, U. Wood-Sichra, and W. Wu (2014). 'Generating Global Crop Distribution Maps: From Census to Grid'. Agricultural Systems, 127: 53-60. Available at: http:/ / mapspam.info (accessed 3 March 2017).

Zabel, F., B. Putzenlechner, and W.Mauser (2014). 'Global Agricultural Land Resources - A Highresolution Suitability Evaluation and Its Perspectives until 2100 under Climate Change Conditions'. PLoS ONE, 9(9): e107522. Doi: 10.1371/journal.pone.0107522. 


\section{Appendix A}

Table A1: Water used for irrigation purposes in the different countries in the sub-region

\begin{tabular}{|c|c|c|c|c|c|c|c|c|c|c|}
\hline & Angola & Botswana & Lesotho & Malawi & Mozambique & Namibia & South Africa & Swaziland & Zambia & Zimbabwe \\
\hline Latest year & 2005 & 2002 & 1999 & 2006 & 2001 & 2002 & 2012 & 2000 & 2002 & 2014 \\
\hline $\begin{array}{l}\text { Area equipped for full control } \\
\text { irrigation: total ( } x 1,000 \text { ha) }\end{array}$ & 85.5 & 1.4 & 2.6 & 73.5 & 118.1 & 7.6 & $1,670.0$ & 49.9 & 55.4 & 150.0 \\
\hline Notes & & & & $\begin{array}{l}\text { AQUASTAT } \\
\text { estimate }\end{array}$ & $\begin{array}{l}\text { AQUASTAT } \\
\text { estimate }\end{array}$ & & & & & \\
\hline Latest year & & & & & & & & & 2002 & 2014 \\
\hline $\begin{array}{l}\text { Area equipped for irrigation: } \\
\text { equipped lowland areas } \\
\text { (x 1,000 ha) }\end{array}$ & & & & & & & & & 100.5 & 25.0 \\
\hline Notes & & & & & & & & & & $\begin{array}{l}\text { AQUASTAT } \\
\text { estimate }\end{array}$ \\
\hline Latest year & & & & & & & & & 1992 & \\
\hline $\begin{array}{l}\text { Area equipped for irrigation: } \\
\text { spate irrigation ( } 1,000 \text { ha) }\end{array}$ & & & & & & & & & 0.0 & \\
\hline Latest year & 2005 & 2002 & 1999 & 2006 & 2001 & 2002 & 2012 & 2000 & 2002 & 2014 \\
\hline $\begin{array}{l}\text { Area equipped for irrigation: } \\
\text { total (x } 1,000 \text { ha) }\end{array}$ & 85.5 & 1.4 & 2.6 & 73.5 & 118.1 & 7.6 & $1,670.0$ & 49.9 & 155.9 & 175.0 \\
\hline Notes & & & & $\begin{array}{l}\text { AQUASTAT } \\
\text { estimate }\end{array}$ & $\begin{array}{l}\text { AQUASTAT } \\
\text { estimate }\end{array}$ & & & & & $\begin{array}{l}\text { AQUASTAT } \\
\text { estimate }\end{array}$ \\
\hline Latest year & 2005 & 1992 & 1999 & 1992 & 2001 & 1992 & 2012 & 2002 & 2002 & 1999 \\
\hline $\begin{array}{l}\% \text { of the area equipped for } \\
\text { irrigation actually irrigated (\%) }\end{array}$ & 13.5 & 100.0 & 2.5 & 96.0 & 33.9 & 100.0 & 95.9 & 90.0 & 100.0 & 71.4 \\
\hline Notes & $\begin{array}{l}\text { AQUASTAT } \\
\text { estimate }\end{array}$ & & & & & & & & & \\
\hline
\end{tabular}

Source: FAO (2016). 
Table A2: Angola

\begin{tabular}{|c|c|c|c|}
\hline Province & $\begin{array}{l}\text { Area equipped for } \\
\text { irrigation (ha) }\end{array}$ & Year & Notes \\
\hline Bengo & 16,592 & & \\
\hline Benguela & 9,051 & & \\
\hline Bie & 0 & & \\
\hline Cabinda & 2,082 & & \\
\hline Cunene & 6,696 & & \\
\hline Huambo & 1,555 & & \\
\hline Huila & 1,605 & & \\
\hline Kuando Kubango & 940 & & \\
\hline Kuanza Norte & 0 & & \\
\hline Kuanza Sul & 25,777 & & \\
\hline Luanda & 8,419 & & \\
\hline Lunda Norte & 0 & & \\
\hline Lunda Sul & 0 & & \\
\hline Malanje & 869 & & \\
\hline Moxico & 117 & & \\
\hline Nambie & 6,297 & & \\
\hline Uige & 0 & & \\
\hline Zaire & 0 & & \\
\hline Angola total & 80,000 & 1975 & $\begin{array}{l}\text { Assumed still valid. It is assumed that less than } \\
50 \% \text { of the area equipped for irrigation is } \\
\text { actually irrigated. }\end{array}$ \\
\hline with groundwater & 16,000 & & \\
\hline with surface water & 64,000 & & \\
\hline
\end{tabular}

Source: FAO (2016).

Table A3: Botswana

\begin{tabular}{|c|c|c|c|c|}
\hline Region & $\begin{array}{r}\text { Area equipped } \\
\text { for irrigation (ha) }\end{array}$ & $\begin{array}{l}\text { Area actually } \\
\text { irrigated (ha) }\end{array}$ & Year & Notes \\
\hline Central & 586.5 & 358.7 & & \\
\hline Francistown & 208.3 & 45.5 & & \\
\hline Gaborone & 149.7 & 38.7 & & \\
\hline North-West & 194.4 & 71.9 & & \\
\hline Southern & 249.9 & 103.3 & & \\
\hline Western & 49.8 & 2.0 & & \\
\hline $\begin{array}{l}\text { Botswana total } \\
\text { with groundwater }\end{array}$ & $\begin{array}{r}1,438.6 \\
665.4\end{array}$ & 620.1 & 2002 & Assumed still valid \\
\hline with surface water & 773.2 & & & \\
\hline
\end{tabular}

Source: FAO (2016). 
Table A4: Lesotho

\begin{tabular}{|c|c|c|c|}
\hline District & $\begin{array}{l}\text { Area equipped } \\
\text { for irrigation (ha) }\end{array}$ & Year & Notes \\
\hline Berea & 0 & & \\
\hline Butha-Buthe & 30 & & \\
\hline Leribe & 993 & & \\
\hline Mafeteng & 605 & & \\
\hline Maseru & 225 & & \\
\hline Mohale's Hoek & 250 & & \\
\hline Mothotlong & 0 & & \\
\hline Qacha's Nek & 0 & & \\
\hline Quting & 535 & & \\
\hline Thaba Tseka & 0 & & \\
\hline Lesotho total & 2,638 & 1999 & $\begin{array}{l}\text { Assumed still valid. Only about } 2.5 \% \text { of the area } \\
\text { equipped was actually irrigated in } 1999 \text {. }\end{array}$ \\
\hline with groundwater & 50 & & \\
\hline with surface water & 2,588 & & \\
\hline
\end{tabular}

Source: FAO (2016).

Table A5: Malawi

\begin{tabular}{lrll}
\hline Region & $\begin{array}{r}\text { Area equipped } \\
\text { for irrigation (ha) }\end{array}$ & Year & Notes \\
\hline Malawi total & 56,390 & 2002 & $\begin{array}{l}\text { Assumed still valid. No data at sub-national } \\
\text { level. In 1996 about 96\% of the area equipped } \\
\text { for irrigation was actually irrigated. }\end{array}$ \\
& & & \\
with groundwater & 30 & \\
with surface water & 56,360 & \\
\hline
\end{tabular}

Source: FAO (2016).

Table A6: Mozambique

\begin{tabular}{|c|c|c|c|c|}
\hline Province & $\begin{array}{r}\text { Area equipped for } \\
\text { irrigation (ha) }\end{array}$ & $\begin{array}{l}\text { Area actually } \\
\text { irrigated (ha) }\end{array}$ & Year & Notes \\
\hline Cabo Delgado & 1,764 & 45 & & \\
\hline Gaza & 50,323 & 8,825 & & \\
\hline Inhambane & 1,285 & 177 & & \\
\hline Manica & 2,067 & 990 & & \\
\hline Maputo & 24,130 & 14,143 & & \\
\hline Nampula & 980 & 610 & & \\
\hline Niassa & 608 & 6 & & \\
\hline Sofala & 24,220 & 13,850 & & \\
\hline Tete & 1,895 & 452 & & \\
\hline Zambezia & 10,848 & 965 & & \\
\hline Mozambique total & 118,120 & 40,063 & 2002 & Assumed still valid \\
\hline with groundwater & 639 & & & \\
\hline with surface water & 117,481 & & & \\
\hline
\end{tabular}

Source: FAO (2016). 
Table A7: Namibia

\begin{tabular}{|c|c|c|c|c|c|}
\hline Basin & $\begin{array}{r}\text { Area } \\
\text { total (ha) }\end{array}$ & $\begin{array}{r}\text { equipped for irr } \\
\text { with } \\
\text { groundwater } \\
\text { (ha) }\end{array}$ & $\begin{array}{r}\text { ation } \\
\text { with } \\
\text { surface } \\
\text { water (ha) } \\
\end{array}$ & Year & Notes \\
\hline Auob & 329 & 329 & 0 & & \\
\hline Cuando & 0 & 0 & 0 & & \\
\hline Cumene and Cuvelai & 714 & 701 & 13 & & \\
\hline Fish & 2,312 & 10 & 2,302 & & \\
\hline Hoanib & 64 & 64 & 0 & & \\
\hline Hoarusib & 0 & 0 & 0 & & \\
\hline Huab & 38 & 33 & 5 & & \\
\hline Koichab & 0 & 0 & 0 & & \\
\hline Koigab & 0 & 0 & 0 & & \\
\hline Kuiseb & 0 & 0 & 0 & & \\
\hline Nossob & 67 & 63 & 4 & & \\
\hline Okavango & 1,350 & 268 & 1,083 & & \\
\hline Omaruru & 73 & 72 & 1 & & \\
\hline Orange & 2,054 & 1 & 2,053 & & \\
\hline South-West Coast & 0 & 0 & 0 & & \\
\hline Swakop & 174 & 41 & 134 & & \\
\hline Trumib & 0 & 0 & 0 & & \\
\hline Tsaris & 0 & 0 & 0 & & \\
\hline Tsauchab & 0 & 0 & 0 & & \\
\hline Tsondab & 0 & 0 & 0 & & \\
\hline Ugab & 198 & 51 & 147 & & \\
\hline Unjab & 0 & 0 & 0 & & \\
\hline Zambesi & 200 & 0 & 200 & & \\
\hline Namibia total & 7,573 & 1,632 & 5,941 & 2002 & $\begin{array}{l}\text { Assumed still valid. } \\
\text { Assumed area actually } \\
\text { irrigated similar to area } \\
\text { equipped for irrigation. }\end{array}$ \\
\hline
\end{tabular}

Source: FAO (2016).

Table A8: South Africa

\begin{tabular}{|c|c|c|c|}
\hline Region & $\begin{array}{r}\text { Area equipped } \\
\text { for irrigation (ha) }\end{array}$ & Year & Notes \\
\hline Eastern & 191,064 & & \\
\hline Free State & 68,809 & & \\
\hline Gauteng & 16,348 & & \\
\hline KwaZulu-Natal & 134,721 & & \\
\hline Mpumalanga & 135,474 & & \\
\hline North West & 114,800 & & \\
\hline Northern Cape & 164,939 & & \\
\hline Northern & 219,319 & & \\
\hline Western Cape & 452,526 & & \\
\hline South Africa total & $1,498,000$ & 2000 & $\begin{array}{l}\text { Assumed still valid. Area actually irrigated assumed } \\
\text { to be similar to area equipped for irrigation. }\end{array}$ \\
\hline with groundwater & 127,330 & & \\
\hline with surface water & $1,370,670$ & & \\
\hline
\end{tabular}

Source: FAO (2016). 
Table A9: Swaziland

\begin{tabular}{|c|c|c|c|}
\hline & $\begin{array}{r}\text { Area equipped for } \\
\text { irrigation (ha) }\end{array}$ & Year & Notes \\
\hline Highveld & 50 & & \\
\hline Lowveld & 41,886 & & \\
\hline Lubombo Plateau & 10 & & \\
\hline Middleveld & 7,897 & & \\
\hline Swaziland total & 49,843 & 2000 & $\begin{array}{l}\text { Assumed still valid. About } 90 \% \text { of the area } \\
\text { equipped for irrigation was actually irrigated. }\end{array}$ \\
\hline with groundwater & 1,000 & & \\
\hline with surface water & 48,843 & & \\
\hline
\end{tabular}

Source: FAO (2016).

Table A10: Zambia

\begin{tabular}{|c|c|c|c|c|c|}
\hline \multirow[b]{2}{*}{ Region } & \multicolumn{3}{|c|}{ Area equipped for irrigation } & \multirow[b]{2}{*}{ Year } & \multirow[b]{2}{*}{ Notes } \\
\hline & total (ha) & $\begin{array}{r}\text { with } \\
\text { groundwater } \\
\text { (ha) }\end{array}$ & $\begin{array}{r}\text { with } \\
\text { surface } \\
\text { water (ha) }\end{array}$ & & \\
\hline Central & 27,200 & 166 & $27,, 034$ & & \\
\hline Copperbelt & 27,800 & 3,000 & 24,800 & & \\
\hline Eastern & 31,510 & 192 & 31,318 & & \\
\hline Lake Mweru & 0 & 0 & 0 & & \\
\hline Luapula & 5,552 & 34 & 5,518 & & \\
\hline Lusaka & 22,100 & 3,000 & 19,100 & & \\
\hline North Western & 576 & 4 & 572 & & \\
\hline Northern & 1,500 & 9 & 1,491 & & \\
\hline Southern & 37,074 & 226 & 36,848 & & \\
\hline Western & 2,600 & 16 & 2,584 & & \\
\hline Zambia total & 155,912 & 6,646 & 149,266 & 2002 & $\begin{array}{l}\text { Assumed still valid. } \\
\text { Area actually irrigated } \\
\text { was similar to area } \\
\text { equipped for irrigation. }\end{array}$ \\
\hline $\begin{array}{l}\text { Area equipped for } \\
\text { full control irrigation }\end{array}$ & 55,387 & & & & \\
\hline $\begin{array}{l}\text { Equipped lowland } \\
\text { areas }\end{array}$ & 100,525 & & & & \\
\hline
\end{tabular}

Source: FAO (2016). 
Table A11: Zimbabwe

\begin{tabular}{|c|c|c|c|}
\hline Province & $\begin{array}{r}\text { Area equipped } \\
\text { for irrigation (ha) }\end{array}$ & Year & Notes \\
\hline Bulawayo & 11 & & \\
\hline Harare & 90 & & \\
\hline Manicaland & 53,756 & & \\
\hline $\begin{array}{l}\text { Mashonaland } \\
\text { Central }\end{array}$ & 22,174 & & \\
\hline Mashonaland East & 9,458 & & \\
\hline Mashonaland West & 33,057 & & \\
\hline Masvingo & 38,772 & & \\
\hline Matabeleland North & 2,243 & & \\
\hline Matabeleland South & 4,990 & & \\
\hline Midlands & 8,962 & & \\
\hline Zimbabwe total & 173,513 & 1999 & $\begin{array}{l}\text { Assumed still valid. About } 71.4 \% \text { of area equipped } \\
\text { for irrigation was actually irrigated. }\end{array}$ \\
\hline with groundwater & 20,000 & & \\
\hline with surface water & 153,513 & & \\
\hline
\end{tabular}

Source: FAO (2016). 